\title{
NEW GENERA AND SPECIES OF GEOMETRIDAE.
}

\author{
By W. WARREN, M.A., F.E.S.
}

THE types of the species here recorded as new are all contained in the Rothschild

Museum at Tring. To these descriptions are added diagnoses of new genera, and a few rectifications of generic and specific names, with critical notes where necessary.

\section{SubFamly OENOCHROMINAE}

Oenochromidae Meyr.

Nearcha ursaria Guen.

Guenée's deseription of ursaria is taken from a o ; the examples in the British Museum, four in number, are all $\delta \delta$, agreeing exactly with his description of the $q$. In these, however, all the nervures of the forewings are thickly traced with hair-like scales, and the neuration itself of the lower nerves is subject to an anomalous distortion, so striking that, did it obtain in the $q$, I think Guenée would hardly have failed to observe it. The submedian nerve, the submedian fold, and the first median nervule are all three abruptly bent downwards beyond the middle of the wing towards the anal angle. This distortion is more especially noticeable in the case of the first median nervule, which runs at a strong angle so as almost to join the fold. The forewings are, as Guenée states, much more strongly falcate than in buffalaria.

I imagine, as Mr. Meyrick makes no mention of these anomalies in his description of buffalaria, which he makes identical with ursaria, that he has never seen the underside of Walker's four $\delta$. Three of these Walker himself referred to buffalaria and one to ursaria, and then added, "These species seem to be identical."

Antasia nom. nov.

Darantasia (Wlk., xxvi., p. 1743, nom. praeoc.).

This name of Walker's cannot stand, as he had already used it (Journ. Linn. Soc., iii., p. 186) for a totally different insect.

\section{Lyrcea (Wlk., xx., p. 259, 1860).}

Meyrick erects a family for the insects of this genus, Lyrceidae; but, as the Oenochromidae, the majority of which are endemic to Australia, Tasmania, and New Zealand are, as far as neuration goes, a somewhat loosely defined family, it seems to me preferable, at all events at present, to include the present genus Lyrcea in it. The species inter se are very variable. Meyrick refers both achroiaria Feld., varians Butler, and ustaria Wlk. to alectoraria Wlk. as one species, to which he adds as a second Hemerophila hemipteraria Guen. (which I have not seen), which he had previously separated under a new generic name Xyridacma. I consider achroiaria Feld. decidedly distinet from the Walkerian species. It is very variable, but achroiaria has a distinct angulation in the outer margin of the forewing, while alectoraria Wlk. is always larger, invariable, with scarcely any markings, and the costal edge red, especially at the base. Ustaria Wlk., the type of which is in the British Museum, and 
is the only one I have seen, may be a form of achroiaria Feld., but it seems doubtful. It differs from all forms of that species that have come under my notice, by having a broad central shade on both wings. As Meyrick makes all four species identical, it is impossible to say to which his description of the larva of alectoraria in Transactions of the New Zealand Institute, 1889, p. 220, really refers. Meyrick formerly included two other Walkerian species under alectoraria Wlk.-viz., Aspilates (?) primata Wlk., xxiv., p. 1076, and Endropia mixtaria Wlk., xxvi., p. 1506; but these, both $\delta \delta$, are given by Walker as having pectinated antennae, which at once precludes their identity with any species of Lyrcea.

\section{Sarcinodes punctata sp. nov.}

Forewings pinkish grey; dusted towards the base and costa with dark seales; costal region red brown, diffuse ; the lines thick, dark reddish brown, edged internally with paler ; first line at one-third, angulated below the costa ; second straight, oblique, from beyond the middle of the costa to before the middle of the inner margin; between these lines a distinct black cell spot; third line from the apex to two-thirds of the inner margin, with a paler internal edging than either of the other lines; subterminal line represented by a series of white dashes on the veins, each with a black tip externally. Hindwings with two straight oblique lines, one near the base before the cell dot, the other about the middle; space beyond it more dusted with blackish atoms, and with the subterminal line more strongly depicted than in the forewings. Head, thorax, and abdomen concolorous with ground colour. Underside pinkish; the first line not represented in either wing; the second a straight reddish line; the third a series of distinct black spots on the veins, on a paler-scaled line; subterminal line sinuous denticulate; hindmargin beyond it reddish brown or fulvous. In the hindwings the basal half is more or less broken up with pale ochreous, and the outer half deeply suffused with fulvous brown.

One $\delta$ from S.E. Borneo; allied to S. aequilineata, but sufficiently distinet.

Alex (Wlk., xxvi., p. 1754).

Type: A. nigrozonata Wlk.

In Alex the neuration of the hindwings is different in the two sexes. In the $q$ the radial rises, as in both sexes of Gamoruna, from the middle of the discocellular. In the $\delta$ it starts from near the base of the subcostal nervule, and out of it, instead of, as is usually the case, out of the discocellular itself. The $\delta$ has the antennae shortly and regularly pectinated.

Of the two species, that from the islands is a much brighter-looking insect than the Indian. The types of both nigrozonata Wlk. and continuaria Wlk., both in the Saunders collection at Oxford, are from Sarawak. In Mr. Rothschild's collection are seven $\delta \delta$ and two $q q$ from $\mathrm{S}$. Celebes, a $\delta$ from Baram, a $q$ from Amboina from the Felder collection, and another $\uparrow$, marked $\delta$, and recorded, undoubtedly by mistake, as from Brazil, which is the type of Drepanodes albicoxaria Feld. These all agree precisely, except that the Amboina specimen has a large dark, roundish discal spot on the forewings, instead of the usual small linear one.

The Indian species varies both in size and coloration, and still more in the distinctness of the markings. The smaller examples, all $\delta \delta$, are dark grey or whitish grey, with a pink tint, but without any fulvous tint. The larger ones, both $\delta \delta$ and 
$q q$, are more or less suffused with fulvous, and in some cases have the oblique dark line all but obsolescent. The synonymy of the island species will be as under :-

Alex nigrozonata Wlk., xxvi., p. 1754 , o

Sarawak.

Orgalima continuaria Wlk., xxxv., p. 1617, $\delta$

Sarawak.

Drepanodes albicoxaria Feld., Reise Nov., Pl. CXXIII., fig. 5, q, not $\delta$, (?) Brazil.

\begin{abstract}
Alex indica sp. nov.
Wings, in the larger type form, and especially in the $q$, grey, with more or less of a fulvous tint, but never nearly so bright as in the island form, nigrozonata Wlk. In this larger form, which is as large as nigrozonata, the markings are almost precisely the same as in that species; but the brown black oblique line is manifestly edged externally with a bright reddish fulvous line, which shows plainer in the $q$; the whole surface is more thickly sprinkled with dark grey transverse streaks. In the smaller form, which seems to be confined to the $\delta \delta$ alone, the fulvous suffusion is quite absent, and the dark markings proportionally developed. In both forms an aberration occurs in which the dark oblique line is entirely wanting in both wings, to which the name obsoleta may be applied. I have seen no instance of this in nigrozonata.
\end{abstract}

A long series from the Khasia Hills.

\title{
GAMORUNA.
}

Gamoruna (Moore, Lep. Coll. Atk., p. 265).

Type: G. palparia Wlk.

The neuration of the hindwings is alike in both sexes, the radial rising in each ease from the middle of the discocellular. The $\delta$ antennae are simple, but finely pubescent.

The $q q$ of Gamoruna may be distinguished from those of Alex Wlk., from which they are otherwise inseparable, by the course of the subterminal line of dark spots. This in Gamoruna runs parallel to the hindmargin; in Alex it is incurved near the costa.

\section{Gamoruna aemula sp. nov.}

Forewings pale grey, thickly strewn with dark grey and blackish transverse striae, especially towards the hindmargin; costa dotted with black. Basal line indicated only by black spots (not always present in $q$ ) on the median nervure, submedian fold, and inner margin. An indistinct, blackish, discal spot (very indistinct in ₹), external line straight, from before apex to two-thirds of inner margin, fawn coloured, edged externally with paler, and marked with black dots on veins (those in $q$ very small), which is followed by a dull grey diffuse shade, which sometimes ends on inner margin in a round black blotch. Hindwings like forewings, but with central line less distinct. Underside paler, with black strigae and discal spots only. Vertex of head, antennae, thorax, abdomen, and legs grey; face and palpi black; tongue and pectus yellowish white.

Expanse of wings : 44 to $48 \mathrm{~mm}$.

Five $\& q$, one $\delta$ from South Africa. 
Conolophia gen. nov.

Forewings with costa straight, convex just before apex; hindmargin oblique, slightly bowed; anal angle obtuse. Hindwings with hind margin rounded and slightly elbowed ; palpi rostriform, black; longer in $q$ than $\delta$; tongue present ; antennae (?). Neuration: forewing with first subcostal free; the rest on a common stem from near the end of cell. The inner margin of the hindwings in the $\delta$, at about halfway, possesses a raised cone of scales, which stands vertically to the plane of the wing.

Type: Conolophia conscitaria Wlk. (Panagra).

\section{Loxorhombia gen. nov.}

Forewings with costa abruptly convex at base, then straight to apex, which is bluntly rounded; hindmargin vertical above, more oblique below, where it becomes subcrenulate. Hindwings with costa straight; hindmargin produced into a prominent sharp tooth at the end of first subcostal; thence sinuous, concave towards the tooth, convex towards the anal angle. Antennae of $\delta$ pectinated, the pectinations fine, straight, oblique; forehead projecting somewhat below; tongue present; palpi projecting beyond face; second joint hairy ; third joint long, pointed; hind tibiae, not thickened, with four spurs. Neuration : forewings, first median from two-thirds, second from seven-eighths, third from end of cell ; radials as usual; fifth subcostal free from seven-eighths; the other four on a common stem from two-thirds, which anastomoses with, or approximates to, the costal. Hindwings with costal running parallel to subcostal for quite half the length of cell.

Type: Loxorhombia idea Swinhoe (Panagra).

\section{Heteralex gen. nov.}

Forewings rather elongate; costa very faintly curved from base to apex, which is shortly and acutely produced; hindmargin obliquely bowed, slightly indented immediately below apex; hindwings ample, with hindmargin well rounded; antennae (ठ) unipectinate; palpi porrect, but only reaching just in front of face; in shape like those of Alex and Gamoruna; hind tibiae with four spurs. Legs and abdomen long. Neuration: forewings, cell half the length of wing; diseocellular angulated, the lower limb oblique; first median nervule at two-thirds; second and third together from lower end of cell ; lower radial from centre of discocellular; upper and fifth subcostal from the upper end of cell; the others on a common stem from a short distance hefore end. Hindwings : cell not half as long as wing; discocellular angulated; subcostal arched upwards, and approximated for some little way to the costal; subcostals from top end of cell ; medians as in forewings.

Type: Heteralex aspersa sp. nov.

\section{Heteralex aspersa sp. nov.}

Wings whitish, mottled with ochreous grey or fuscous dots and striae; a straight dark fuscous line from just before apex of forewing to the middle of the inner margin of hindwing, followed by a darker tinge than the rest of the wing; a small dark dot near the base of forewing, and three more in a curve representing the first line; a distinet black cell spot; from the base an interrupted dark grey shade stretches below the costa as far as the cell, a row of minute black dots at base of fringes, between the veins; hindwings like forewings, but the cell spot not so plain; fringes 
all concolorous; thorax and abdomen whitish grey; antennae yellowish. Underside whiter, with the markings darker and more contrasted; in the forewing a curved row of fuscous dots on the veins precedes the oblique line; in the hindwing a strongly denticulated line follows it.

Expanse of wings : o, $34 \mathrm{~mm}$.

One $\delta$ from Padang Rengas.

Monotaxia gen. nov.

Forewings with costa straight; convex only just before apex, which is not produced; hindmargin oblique, curved before anal angle; hindwings with hindmargin rounded. Antennae of $\delta$ unipectinate, curved; apical one-third filiform ; palpi not long; porrected; second joint broad; third short, drooping; tongue present. Neuration: forewings, first median at three-fourths, second at nine-tenths, third from end of cell; fifth subcostal at nine-tenths; joint stem of the other four at thyee-fourths. Hindwings, like those of Loxorhombia Warr.

Type: Monotaxia rectilineata Guen. (Cassyma).

As Guenée's genus Cassyma is a mixture, his first species must be regarded as the type. It therefore becomes necessary to find a fresh generic term for this species, the $\delta$ of which was unknown to Guenée.

\section{Palaeaspilates gen. nov.}

Forewings elongate, triangular; costa nearly straight; apex blunt; hindmargin obliquely curved; hindwings with hindmargin entire, rounded; $\delta$ antennae plumose, rather long ; palpi short, straight; third joint invisible; tongue present; hind tibiae not thickened, with four spurs. Neuration: cell half as long as wing; discocellular convex ; first median at three-fourths, second just before end, third from the end of cell; lower radial from centre of discocellular, upper from three-fourths of the discocellular; last subcostal from top end of cell, and from the same point, or only just before it rises the common stem of the other four. Hindwings: costal approximated to subcostal for some little way near base; two subcostals on a very short stalk ; radial from middle of discocellular; medians as in forewings.

Type: $P$. inoffensa sp. nov.

\section{Palaeaspilates inoffensa sp. nov.}

Forewings dull olive yellow, thickly dusted with fine grey atoms; a thick diffuse straight grey exterior line from two-thirds of inner margin to costa before apex, becoming obsolete before reaching the costa; a dark grey discal spot, and a very faint curved basal line. Hindwings the same colour, but without markings. Underside like upper, but all the markings darker. Head, antennae, thorax, and abdomen concolorous.

Expanse of wings : $36 \mathrm{~mm}$.

One $\delta$ from Knysna (Cape Colony), from the Felder collection.

Superficially exactly like a dull looking Aspilates gilvaria.

\section{Panagropsis gen. nov.}

Like Gamoruna Moore, but distinguished by the $\delta$ antennae which are fully pectinated.

Type: P. equitaria Wlk. (Panagra). 
The only African species which Guenée puts into his genus Panagra, and that the second group is saxaria, which he compares with, and considers to be probably a form of, the common European Panagra petraria (Lozogramma). All the rest belong to one or other of the Australian genera of Oenochromidae. The African species, which is here put forward under the new generic term of Panagropsis, has the $\delta$ antennae pectinated, and the radial of the hindwing present; but is devoid of the tufts of hair on the underside of the hindwings, which occur in the Australian genus Nearcha Meyr., the species of which have, like Panagropsis, pectinated antennae in the $\delta$.

Dolerophyle gen. nov.

Forewings elongated, ample; costa strongly curved from base to apex, which is sharp and slightly produced; hindmargin oblique, and curved just before the anal angle. Hindwings oblong, the costal and inner margins being nearly parallel; hindmargin slightly curved. Antennae (ठ) curved, with very fine pectinations (or long ciliations), gradually decreasing to apex; palpi porrect, weak; tongue present; legs long and weak; hind tibiae with four spurs. Neuration as in Achlora Guen.

Type: Dolerophyle nerisaria Wlk. (Oxydia).

Superficially this insect reminds one of Oxydia, but the whole structure is much weaker.

The synonymy of the only species is as follows:-

Dolerophyle nerisaria.

Oxydia (?) nerisaria Wlk., xx., p. 223, ๆ. Type in S.C.

Amazons.

Budara conversata Wlk., xxvi., p. 1690, $\delta$. Type in Fry C. Rio Janeiro. Gynopteryx tendinaria Feld., Reise Nov., Pl. CXXIII., fig. 24. Type in R. C.

\section{Achlora Guen.}

Of the five species which Guenée placed under Achlora he knew the $\delta$ of one only-viz., cuprearia: of which he describes the antennae as finely and shortly pectinated, and draws attention to the tuft of hair on the underside of the hindwings in this sex. He also implies that the palpi in the $q$ have a very much longer terminal joint than in the $\delta$. Both perigearia Guen. and cuprearia Guen. agree in these points; a third species, almost certainly Hübner's injunctaria, is without the tuft of hair; all these three species have the lines and discal spots well marked on the underside. Guenée's other two species belong to quite another genus; ef. Pycnoneura Warr.

As Guenée knew the $\delta$ of cuprearia only, I propose to name that species as the type of the genus.

\section{Dolichoneura gen. nov.}

This genus resembles Pycnoneura Warr., but the shape of wing and neuration is the same in both sexes, resembling that of the $q$ of Pycnoneura. There is no thickening, nor contortion of the veins of the hindwings in the $\delta$.

Type: Dolichoneura albidentata sp. nov. 


\section{Dolichoneura albidentata sp. nov.}

Wings dark mouse coloured, slightly glossy; the lines sinuous, whitish; first at one-third, geminated; second at two-thirds geminated, angulated below the costa, then parallel to the hindmargin; subterminal single; underside dull mouse colour without markings. Head, thorax, and abdomen all concolorous.

Expanse of wings: $\delta, 34 \mathrm{~mm}$. ; $\uparrow, 36 \mathrm{~mm}$.

A pair from Rio Demerara.

\section{Dolichoneura innotata sp. nov.}

Wings dull mouse coloured, with scarcely any markings; a darker cell spot in the forewings, followed by a curved, very indistinct denticulated darker line, which also crosses the hindwings about the middle. Head, thorax, and abdomen concolorous. Underside paler, with no markings.

Expanse of wings: $\delta, 42 \mathrm{~mm}$; $\uparrow, 38 \mathrm{~mm}$.

A pair from Rio Demerara.

Neither of the two examples is in very good condition; fresh specimens would probably show some more distinct markings.

\section{Euctenachlora gen. nov.}

Resembles Achlora Guen., but the forewings are more pointed, and the antennae of the $\delta$ are very fully pectinated to the apex, the pectinations themselves finely eiliated; hindwings of $\delta$ without tufts of hair beneath.

Type: Euctenachlora caenobiata Feld. (Achlora).

\section{Leptoctenista gen. nov.}

Forewings ample; costa slightly arched near base and before apex, nearly straight between; apex shortly and finely produced; hindmargin strongly curved, and slightly indented below apex; anal angle squared. Hindwings triangular; costal and inner margins nearly straight; hindmargin very slightly curved. Antennae of $\delta$ regularly ciliated, the ciliations oblique and gradually diminishing towards apex; palpi upeurved in front of face; basal joint hairy, second and third smooth; tongue present, hind tibiae not thickened, with four spurs. Neuration: cell half the length of the wing; discocellular straight; first median at two-thirds; second just before the end, third from the end of cell; lower radial from centre of discocellular; upper from top end of cell; last subcostal from before end, upcurved towards the others; fourth rising in front of fifth, anastomosing with the costal, and with the others leaving it at equal distances. Hindwings with costal and subcostal slightly approximating near base; first subcostal just before end of cell; medians as in forewing.

Type: Leptoctenista calexaria Wlk. (Gynopteryx).

\section{Panulia gen. nov.}

Forewings ample; costa gradually, but very slightly, curved from base to apex, more convex just before apex; apex blunt; hindmargin hardly perceptibly indented immediately below apex, then slightly bowed, and afterwards running obliquely to anal angle. Hindwings broad; hindmargin irregular, and slightly 
projecting opposite the three median nervules; anal angle square. Antennae, o filiform with very short and fine ciliations, appearing pubescent; palpi stout, upcurved in front of face and applied to it; third joint small, obtuse; tongue present; hind tibiae of $\delta$ considerably thickened and bearing a pencil of hairs, with four spurs, the upper pair of unequal length. Abdomen with lateral and ventral tufts of hair. Hindwings with a large curled wisp of hair on the inner margin just before the middle; a flat tuft on the median nervure before the first median nervule on the underside; another on the third median nervule; and a bed of woolly scales between the first and third nervules. Neuration: forewings, cell not quite half the length of wing; discocellular obliquely crescentic; first median starting at three-quarters, second close before the end, third from the lower end of cell; lower radial from centre of discocellular; upper from top angle of cell ; last subcostal from just before the end curved upwards and approximated to the common stem of the other four. Hindwings with costa quite free; first subcostal and second median each starting just before the end of cell.

Type: Panulia achloraria sp. nov.

The genus is manifestly related to the second section of Guenée's Achlora (that for which I retain his name), and also to Noreia Wlk.

\section{Panulia achloraria sp. nov.}

Wings chocolate grey, immaculate; the lines, discal spot, and basal line of fringe red brown; first line at about one-third, curved and slightly wavy; second at two-thirds, at first outwardly, then inwardly oblique, forming a blunt curve at one-third from the costa; discal mark curvilinear, following the discocellular; fringe concolorous, with a slightly paler basal line beyond the dark brown line. Hindwings the same, but without the first line; abdomen concolorous, the tufts blackish brown. Underside duller, not so reddish tinged, with similar markings. Palpi nearly black.

Expanse of wings : $\delta, 52 \mathrm{~mm}$. fine insect.

Several $\delta \delta$, but no $q$, from S. Celebes, taken by Doherty. A dull coloured but

\section{Pycnoneura gen. nov.}

§. Forewings elongated; costa straight till shortly before apex, where it becomes abruptly convex; apical region produced; hindmargin below apex shortly vertical, then oblique and subconcave to anal angle, which is well marked. Hindwings broad, triangular; hindmargin gently rounded, with both angles strongly marked, the anal angle being somewhat produced longitudinally. Antennae filiform, pubescent; palpi slender, upcurved in front of face; terminal joint short, acute; tongue present; hind tibiae with four spurs. $q$ with forewings broader, less elongated ; the apex acuminate, subfalcate; the hind margin obliquely curved from just below apex to the anal angle. Antennae filiform, simple. Neuration: forewings, cell only two-fifths of the wing; discocellular oblique, parallel to hindmargin, slightly angulated in middle. First median nervule before half, second at about three-fourths, third from lower end of cell; lower radial from the angulation of the discocellular; upper from the top end of cell; last subcostal from before end of cell, approximated to the common stem of the other four, and terminating below the alex. Hindwings with neuration somewhat distorted; 
cell hardly one-fifth of wing; discocellular bent; costal vein free, but approximated shortly to subcostal near base; second subcostal apparently rising from the upper part of the discocellular; radial from the angulation; third median from lower end of cell, straight; first and second from shortly before the end, at even distances, suddenly curved downwards after starting; all the nervures are thickened beneath with scales, the submedian being especially noticeable; the costa of the hindwings is bulged between the base and centre. In the $q$ the neuration and clothing of the hindwings is simple, as in Achlora Guen.

Type: Pycnoneura oxypteraria Guen. (Achlora).

This new genus is necessary for Guenée's first section of Achlora.

\section{Racasta Wlk.}

Racasta Wlk., xxiii., p. 830.

Syllexis Guen., Phal., ii., p. 50.

Guenée's second species of Syllexis, spatiaria, of which Walker's Racasta caberaria is a synonym, is not congeneric with his first species, which is the type of the genus, and Walker's name Racasta will supersede it.

\section{Abraxaphantes gen. nov.}

Forewings with costa gradually arched; apex rounded; hindmargin obliquely curved; hindwings with hindmargin eurved, and interior angle somewhat produced; abdomen of $\delta$ long and slender; palpi porrect, long, plumose; tongue present, slender; antennae in both sexes unipectinate. Neuration: cell more than half the length of wing, the margins approximating towards the end; first median nervule at two-thirds; second at five-sixths; third from lower angle of cell ; radials as usual ; last four subcostals on common stem, which is approximated to the first. Hindwings with costal approximated to subcostal for half the length of cell ; first subcostal from well before the upper angle of cell; radial from centre of discocellular; medians as in forewings.

Type: A. perampla Swinhoe (Abraxas).

\section{Anisopteryx japonensis sp. nov.}

The same size as $A$. aescularia of Europe. Both wings dull smoky grey, without any admixture of ochreous or fuscous, which appears in the forewing of aescularia; central fascia scarcely darker than the rest of the wing; its inner edge more oblique, less angulated; no dark discal spot, but the discocellular indicated by a curved dark line; hindwings with only a trace of a slightly darker discal spot.

Two $\delta 8$ from Japan.

\section{Egea Dup.}

Duponchel established the genus Egea for desertaria Frr. = culminaria Eversm., and also placed in it, wrongly, another species, pravata, which Guenée says he (Duponchel) had not seen. He must in that case have characterised the genus from culminaria, for which H. S.'s later name Eremia is therefore not required. Pravata is the type of Hübner's genus Ithysia. 


\section{Subfamily EUMeLEINAE.}

Mecoceridae Guen.

Eumelea Westw., Dunc. Nat. Libr., xxxvii., p. 215.

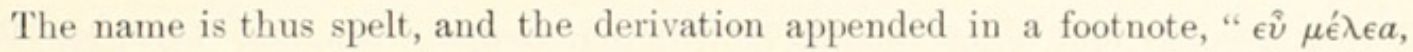

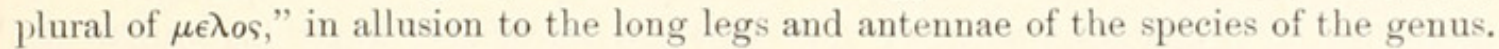
On the plate, however, which immediately precedes the descriptive letterpress, the word is spelt Eumelia. This is manifestly a typical error, and, in face of the positive explanation on p. 215, cannot be allowed to stand.

\section{Eumelea degener sp. nov.}

ठ. Forewings yellow, wholly suffused with bright rosy; the three lines finely purple rosy. Hindwings rather deeper rosy. Underside dull yellow dappled with rosy, with the lines purple rosy.

q. Pale yellow, dusted with rusty atoms, with the lines rusty grey, the subterminal being composed of small blotches, which are sometimes subcontinuous. On the underside these blotches have a purplish tinge.

Expanse of wings: $\delta, 34 \mathrm{~mm}$; $\uparrow, 36 \mathrm{~mm}$.

Distinguished at once by its diminutive size.

Several examples, all from Lifu.

\section{Eumelea obliquifascia sp. nov.}

Forewings: orange thickly suffused with rosy, so that the ground colour is almost lost, except at the extreme apex ; costa blackish ; first line hardly indicated ; diseal ringlet fairly distinet; second and third lines purple rosy, the second running obliquely from costa to inner margin, parallel to the hindmargin. Hindwings : o like forewings, with two lines less distinct. Forewings: $q$ yellow, with the markings rusty red; hindwings the same. In this sex the yellow ground colour is only slightly dusted with rusty atoms. Distinguished from all other species by the direction of the second line.

Expanse of wings : ơ, 52 to $56 \mathrm{~mm}$.; + , $58 \mathrm{~mm}$.

Four $\delta \delta$ and one $q$, from Felder collection, from Amboina. One of the $\delta \delta$ is labelled Eumelea rosalia Cram.; but they do not answer to Cramer's figure any more than others of the genus.

\section{Hedyle Guen.}

Hedyle Guen., Phal., ii., p. 521.

Type: H. heliconaria Guen., l.c., p. 522.

Guenée knew only the $\delta$. To the particulars of his diagnosis must be added : antennae of $q$ pectinated as well as $\delta$; neuration of hindwings in $\delta$ simple.

\section{Hyphedyle gen. nov.}

Resembles Hedyle Guen., in having the hindwings of the $\delta$ simple; but differs from that genus in the structure of the antennae of the $\delta$, which are thickly ciliated, not pectinated.

Type: Hyphedyle rubedinaria Wlk. (Phellinodes). 


\section{Phellinodes Guen.}

Phellinodes Guen., Phal., ii., p. 523.

Type: P. satellitiata Guen., l.c., Pl. XXI., fig. 8.

The genus may be at once separated from Hedyle Guen. and Hyphedyle Warr. by the distorted neuration of the $\delta$ hindwings. Guenée, after describing satellitiata, gives the type as a $\delta$; but in his previous remarks on the genus he laments that he had only a single mutilated specimen, of which the sex was doubtful. It would not be wrong, I think, to conclude that the specimen was a $q$, as Guenée would have been almost sure to remark the peculiarity in the neuration in the $\delta$.

\section{Phellinodes hedylaria sp. nov.}

Forewings whitish, suffused towards the costal and inner margins with pale brownish, and crossed by numerous sinuous black transverse striae, which towards the costa and inner margin are thicker and partially confluent; the disc and lower part of the hindmargin remain clearer white; apex of wing occupied by a yellow brown spot, edged with blackish striae; before it, on the costa, is a large pure white triangular blotch. Hindwings with the dise whitish speckled with blackish; costal, hind, and inner margins broadly bordered with brownish grey, which is somewhat dappled towards the anal angle. Head, thorax, and abdomen fuscous grey. Underside very much like upper, but the dark borders of the hindwings are wanting.

Expanse of wings: $56 \mathrm{~mm}$.

One example from South America.

\section{Almodes terraria.}

Almodes terraria

Polysemia stellidaria

Boarmia squamigere

Cidaria balteolata

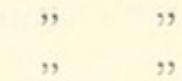

Ergavia assecoma

calvina

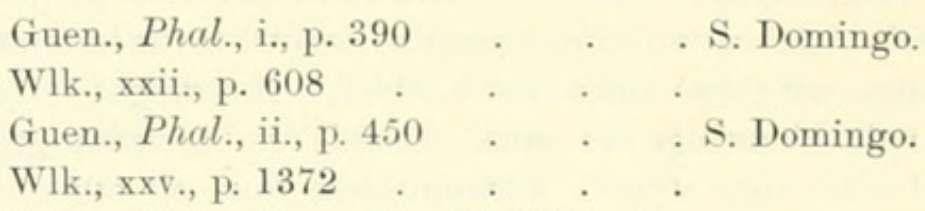

Feld., Reise Nov., Pl. CXXVI., fig. 11 , $. \quad . \quad . \quad$. Bogota.

H. S., Corr. Bl. (Cuba), No. 59 . . Cuba.

Gundl., No. 409 . . . . . ”

Moeschl., Portorico, p. 272 . . . Portorico.

Druce, Biol. Centr. Am. Lep. Het., ii., p. $79, \mathrm{Pl}$. XLVIII., figs. 24,25

Druce, Biol. Centr. Am. Lep. Het., ii., Pl. XLVIII., fig. 21, only . .

\section{Polysemia carinenta.}

Phal. geom. carinenta Cram., Pap.Ex., ii., p. 47, Pl.CXXVIII.,

fig. F. . . . . Coromandel Coast (?).

Boarmia ," Wlk., xxi., p. 370

Dryocoetis carinentaria Hüb., Verz., p. 316 . . .

Boarmia ,

Phalaena carinata

Guen., Phal., i., p. 240 . . Surinam.

Polysemia liraria
Guen., Phal., ii., p. 451, ․ . S, Domingo.

Wlk., xxv., p. 1372 


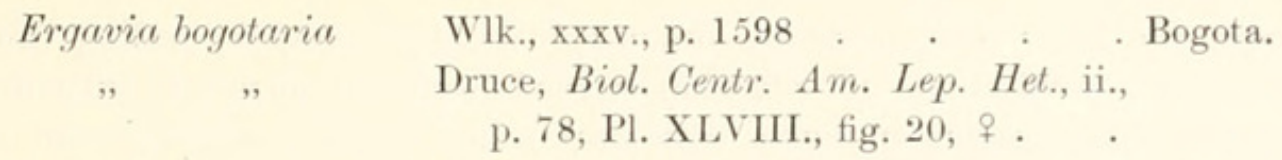

The above synonymies will, I believe, be found correct. Almodes Guen. has pectinated antennae in the $\delta$; in Polysemia they are armed with fascicles of eilia; both possess a radial in the hindwing, and are akin to the genera Mecoceras Guen., and Ametris Hüb. Cramer's locality for carinenta - the Coromandel coast is almost certainly an error. Guenée even makes it Surinam, from whence most of Cramer's species came. Two more genera of Gueneé's, Cerotricha and Odysia. are almost certainly referable here; Taiti, the locality given for Cerotricha licornaria, being probably an error for Haiti.

\section{SubFamily ORTHOSTIXINAE.}

\section{Orthostixidae Meyr.}

Desmobathridae Meyr.

\section{Celerena pallidicolor sp. nov.}

Wings pale primrose; costa of forewings concisely black from base; a broadish, slightly oblique black bar just before the middle runs from the costa, where the basal black costal streak stops, to the anal angle; its outside edge is straight and well defined, the inner edge diffuse; apex broadly black, connected with the central bar by a narrow black curved space at the anal angle. Hindwings with the hindmargin broadly black at the apex, only half as broad along the hindmargin. Head, thorax, and abdomen pale primrose. Underside like upper. The pale apical blotch of the forewings between the central bar and the dark apex is large and broader at its end above the anal angle than on the costa.

One $\&$ from Waigiou, from the Felder collection, about the same size as perithea Cram. Easily distinguished from all other species by its pale primrose ground colour.

\section{Celerena stenospila sp. nov.}

Forewings dull dark, brownish grey, with the base from the inner margin indistinctly yellowish as in perithea Cram. The yellow apical marking is very narrow, not more than half as broad as in perithea. Hindwings yellow, with a blackish border, which is broader than in any example of perithea. One $\delta$ example from Amboina, from the Felder collection.

\section{Naxa guttulata sp. nov.}

Wings smoky white; base of costa black; all the spots smoky grey, blurred; the basal and subterminal laterally produced; the terminal series rounder, and also the discal spots; the smallest species of the genus.

One $\delta$ from Borneo, unnamed, in the Felder collection.

Two others, also $\delta \delta$, from Borneo, in the British Museum.

\section{Hemigymnodes gen. nov.}

Forewings with costa faintly curved throughout; apex blunt; hindmargin obliquely curved, more oblique in the lower half than in the upper; hindwings 
rather narrow, the inner margin short; hindmargin weakly rounded; scaling thin, and rather glossy; palpi short, not reaching beyond face; antennae ( $\delta$ ) with fine pairs of curled cilia; tongue present; legs weak; hind tibiae, as far as can be seen, with only one pair of spurs. Neuration: forewings, cell half as long as wing; first median nervule at four-fifths, second shortly before end, third from end of cell; lower radial from centre of discocellular, upper radial from upper angle of cell; fifth subcostal from just before end of cell, curved upwards and closely approximating to common stem of the next three, which run shortly into costa from this common stem; first subcostal apparently free from the base, running close to the subcostal nervure as far as end of cell, and approximating to or anastomosing with the stem of the next three beyond the cell. Hindwings with costal united to subcostal by a bar near base; two subcostals on a rather long common stem; radial from centre of discocellular; medians as in forewings.

Type: Hemigymnodes nitida sp. nov.

Hemigymnodes nitida sp. nov.

Wings dull grey, semitransparent, each with a pale discal spot. The forewings with another slightly paler spot on the middle of the inner margin; underside the same; abdomen and legs concolorous with wings; head, face, thorax, pectus, and base of last abdominal segment dull orange.

Expanse of wings: $30 \mathrm{~mm}$.

Two of o from Costa Rica.

\section{Mimaletis gen. nov.}

Superficially very much like Aletis Hiib., but differs in the neuration, and in the $q$ antennae. In the forewings the costal and first subcostal nervule are united from near the base, and the $f$ antennae are shortly and stoutly pectinated, as in Terina Wlk., not beset with fascicles of cilia.

Type: Mimaletis postica Wlk. (Aletis).

\section{Mimaletis humilis sp. nov.}

q. Forewings orange red, apical one-third black, its inner edge running from just beyond the middle of costa, oblique and slightly irregular, to the anal angle, forming a small blunt tooth inwards in the cell; in this apical third an oblique oblong white blotch, consisting of four oblong blotches divided by the two radials, and vertically beneath it a small white spot. Hindwings with hindmargin bordered with black, more narrowly than in M. postica Wlk., with five white horseshoe shaped marginal markings; its inner edge consists of regular curves, as in A. helcita Linn.; a small round black spot at end of cell, which appears much further from the hindmargin than in postica Wlk., owing to the narrowness of the marginal band. Underside like upper. Head, thorax, and abdomen (apparently) blackish; but there may have been a series of white dorsal spots when fresh.

Expanse of wings: $52 \mathrm{~mm}$.

One $q$ from the Gaboon River.

Cartaletis gen, nov.

Near Aletis Hüb., but differing especially in the structure of the $\delta$ antennae, which are strongly pectinated, instead of bearing fascicles of cilia.

Type: Cartaletis libyssa Hopf. (Aletis). 


\section{Leptaletis gen. nov.}

Intermediate between Cartaletis Warr., and Paraptychodes Warr., agreeing with the former in neuration and antennal structure, and with the latter in the very much weaker build and consistency of the wings, and in the character and variability of the markings and colouring.

Type: Leptaletis variabilis Butler (Aletis).

\section{Leptaletis pallida sp. nov.}

Forewings white, orange at base; costa and apical third smoky black, the latter with two larger and two smaller white spots; hindwings white with a black border, the inner edge of which is marked with a series of wedge-shaped projections.

Slightly smaller than $L$. variabilis Butler.

A pair from Sierra Leone. One of in British Museum.

\section{Paraptychodes gen. nov.}

ठ. Forewings triangular; costa straight, convex at base and before apex, which is bluntly rounded; hindmargin oblique, somewhat protuberant below apex; inner margin convex; anal angle hardly marked; fovea present. Hindwings small, rounded ; inner margin with a semi-elliptical flap, which is folded over on the underside, the space above it on the upper surface being marked with blackish scales; antennae pectinated, the pectinations stout and short; palpi weak, porrect; tongue present; hind tibiae thickened, with two short spurs; hind tarsi short. Neuration: forewings with cell two-thirds as long as wing; the margins approximating towards end; discocellular irregular in shape; first median nervule at three-fourths; second at seven-eighths; third from end of cell ; lower radial from the centre of discocellular, upper from upper angle of cell; third, fourth, and fifth subcostals on common stem rising a little before end of cell at the point where the subcostal nervure is bent downwards; second subcostal at seven-eighths; first at three-fourths; the latter free, the second anastomosing with the stem of the other three. Hindwings : costal and subcostal approximated for half the length of cell; two subcostal nervules from upper angle; radial from centre of discocellular; first median at half; second at seven-eighths ; third from end of cell.

q. With wings longer and narrower; hindmargin of forewings not protuberant below apex; antennae with short strong pectinations.

Type: Paraptychodes tenvis Butler (Aletis).

Butler's examples of temuis were all $q f$, as also the type of Hampson's fulva, which seems identical.

\section{Palaeomystis gen. nov.}

Forewings ample, elongate; costa straight in the middle, arched at base and convex before apex, which is slightly and bluntly produced; hindmargin sinuous, incurved beneath apex, then bowed, and oblique above the anal angle, which is still distinct. Hindwings narrow, the apex almost more falcate than that of the forewings; hindmargin sinuous; anal angle rounded off. Palpi very short, not reaching front of face; antennae simple, thickened in $\delta$; tongue present; hind tibiae of $\delta$ with four spurs. Neuration: forewings, cell half the length; discocellular 
angulated, the lower arm oblique; first median at half; second a little before, third from, the end of cell; lower radial from a little above the angulation of the discocellular; upper from the top end of cell ; last four subcostals on common stem; first free. Hindwings : discocellular angulated, the lower arm, in the $\delta$, itself bent outwards; costal approaching subcostal a little way from base ; first subcostal well before the end of cell, second from end, running nearly into the middle of the hindmargin; radial from the bend in the lower arm of the discocellular; third median from lower end of cell ; first and second at even distances shortly before the end, both running into the inner margin, which is cut away and leaves no room for an interior vein, except quite close to the margin. In the $q$ the lower arm of the discocellular is straight, and the radial starts from the angulation, while all the three medians run into the hindmargin. Scaling semidiaphanous.

\section{Type: Palaeomystis falcataria Moore (Urapteryx).}

\section{Archaeopseustes gen. nov.}

Forewings ample, triangular, with costa nearly straight, convex just before apex, which is bluntly rectangular; hindmargin evenly and obliquely curved; anal angle rather prominent. Hindwings rather short and narrow, in comparison with forewings ; hindmargin rounded. Forehead sloping; face strongly and bluntly protuberant; antennae (ठ) stoutly bipectinated to near the apex ; tongue present ; palpi horizontal, second joint woolly, terminal small, smooth ; all femora and pectus hairy ; hind tibiae with four spurs; abdomen with slight lateral tufts. Neuration: forewings, cell not half the length of the wing; discocellular crescent shaped; first median nervule at three-fourths, second just before, third from, the end of the cell ; lower radial from centre of discocellular; upper from upper angle of cell ; last four subcostal nervules on a common stem, starting from close to angle of cell, second leaving first, fifth next, third and fourth parting shortly before apex ; first subcostal free, from just before end of cell ; hindwings with costal shortly approximated to subcostal near base ; both subcostals from top end of cell ; rest of neuration as in forewings.

Type: A. amplificata Wlk. (Abraxas).

\section{Tosaura (?) pallida sp. nov.}

Forewings white, with a tinge of yellow, sparsely sprinkled with olive fuscous atoms ; first line indicated only by an inwardly oblique blackish costal blotch ; second line by a similar but rather broader one on the costa ; a faint olive patch in the centre of the wing, and a small darker one on the inner margin; hindmargin with a small dark blotch above and below the elbow ; fringe dark, except at the elbow. Hindwings with a pale olive fuscous fascia at two-thirds from the base. Head, thorax, and abdomen concolorous with forewings.

Expanse of wings : $28 \mathrm{~mm}$.

One $q$ from Japan. The example above described is a good deal worn, but is manifestly a distinct species. I am not certain that it is a true Tosaura, as the palpi appear to be much longer than in the two Indian species of the genus, and more rostriform.

\section{Desmobathra plana sp. nov.}

Wings all deep yellow above and below, with no markings whatever except two small brown costal spots, which indicate the origin of the transverse lines. Head, thorax, and abdomen concolorous.

Expanse of wings : $22 \mathrm{~mm}$.

Two of o from Lifu. 


\section{SubFamily PSEUDOTERPNINAE.}

\section{Actenochroma cristata sp. nov.}

Wings dull olive green, with indistinct darker green transverse mottlings; costa of forewings hardly shouldered at base, and slightly concave in the middle; costa itself concolorous with ground colour, but mottled with dark; basal line almost obsolete; exterior line denticulate, indistinct, expressed by black dashes on veins; submarginal line indistinct, expressed by pale blotches; space between exterior and submarginal lines darker, especially just level with the cell and above the inner margin, where the markings become diffusedly blackish; basai line of fringes incomplete, shown only by black dots between the denticulations. Underside bright, pale ochreous, with no yellow tint; spots and submarginal band strongly black, the latter tinged with reddish ; cell spots of the upperside small, black, with raised scales.

From Bhotan, Sikkim, S. Celebes. Many o $\delta$. This, perhaps, is identical with subtepens Wlk. from Borneo.

\section{Actenochroma flavibasalis sp. nov.}

Forewings greenish white, with dark green mottlings and suffusion; this suffusion is most evident at the base and along the costa of the forewings; a dark green curved basal line, starting from a deeper green spot on costa, and nearly touching a dark green discal elongated spot; second line dark green, strongly denticulated; a wavy green subterminal line; fringes pale olive green, preceded by a row of dark green spots between the veins; the first line is preceded on the inner margin, and the second line followed on the inner margin, and in the centre by patches of mixed reddish and blackish scales. Hindwings like forewings, but without the dark basal line and its reddish blotch. Head, thorax, and abdomen pale green, mottled with darker. Underside pale straw colour, strongly suffused from the base outwards with orange yellow ; a large black oval discal spot in forewings; a broad black fascia, which in the forewings has its inner edge sinuous, and contains a pale apical patch, and in the hindwings has the inner edge perfectly straight, and the outer deeply and evenly dentated.

One $\delta$ from Java.

\section{Actenochroma subochracea sp. nov.}

Forewings yellowish green, mottled with darker green and blackish; costa flecked with blackish; basal line blackish, straight, interrupted, mixed with pinkish scales; a small black discal spot; second line blackish, denticulated, with a few pinkish scales in the denticulations, followed by a more or less continuous series of blotches, consisting of blackish and pinkish scales; a submarginal line of blackish spots; fringe concolorous, with a blackish lunule at the base between the veins, and a minute black dot at the end of the veins. Hindwings like forewings, but with the base more mottled with darker; hindmargin deeply and irregularly crenulate. Head, face, and thorax dark green; antennae and abdomen paler and more ochreous. Underside testaceous, strongly suffused, especially towards the hindmargins, with reddish, which more or less breaks up the blackish marginal fascia; all the veins reddish; a large round blackish cell spot in both wings.

Several $\delta$ o from the Khasia Hills. 


\section{Actenochroma subopalina sp. nov.}

Forewings dull green, very finely dusted with blackish atoms; costa very minutely mottled with blackish, except towards apex, where it is more evidently marked with blackish and pinkish; basal line blackish, mixed with pinkish scales, forming two or three indistinct curved teeth; a small blackish discal dot; second line blackish, denticulated, followed by a band of contiguous blotches of pale pinkish and blackish scales; submarginal line obsolete; fringe concolorous, with a small dark spot at base between the veins. Hindwings the same, but with the base for some distance a mixture of blackish and pinkish scales. Head and thorax green; abdomen and face paler. Underside delicate pale opaline green; in the forewings with some sparse darker mottlings towards the hindmargin; both wings with a largish round black cell spot, and a pinkish brown fascia towards the hindmargin, which has both margins in the forewings diffuse, but the inner margin on the hindwings concise.

One $\delta$ from the Khasia Hills.

\section{Dindica marginata sp. nov.}

Closely related to Dindica polyphaenaria Guen.; forewings precisely the same, except that the dark costal blotch beyond the exterior line is wanting. Hindwings much brighter orange, with a much narrower black border; which is not much wider at the anal angle than at the inner. Underside with the basal two-thirds brighter yellow; the black fascia in both wings touching the hindmargin throughout, and leaving no white included spot; that in the forewings being double the width of that in the hindwings. Abdomen beneath and on sides bright orange.

One $\delta$ from S. Celebes, the same size as polyphaenaria Guen.

\section{Pingasa candidaria sp. nov.}

Like crenaria Guen., but decidedly larger; the hindmarginal area much paler, the lines and discal dash more strongly expressed; the black fascia of the underside more restricted, and no trace of yellow at the base of either wing.

Expanse of wings: $\delta, 48 \mathrm{~mm}$.; $\uparrow, 52 \mathrm{~mm}$.

Several examples of both sexes from Australia.

\section{Pingasa cinerea sp. nov.}

Forewings silvery grey, densely dusted throughout with darker olive grey scales; first line fine, dark grey, tinged with reddish, forming two rounded projections, between costa and inner margin; second line fine, blackish, denticulated, followed by a darker shade, in which are some pinkish scales; fringes pale grey with a fine dark basal line; discal dot small, dark, inconspicuous. Hindwings the same, but more thickly dusted with darker scales, especially in the costal region, and with more decidedly pinkish seales beyond the second line. Head, thorax, and abdomen pale grey, dusted with olive fuscous; the face and abdomen paier than the rest; tufts of the hindwings and crests of abdomen whitish. Underside dull whitish, tinged with cinereous in the forewings especially ; a broad, smoky black hindmarginal fascia, touching the margin throughout, and leaving the fringes whitish; forewings with costa and diffuse cell mark smoky black.

One $q$ from Australia. 
Pingasa javensis sp. nov.

Like crenaria Guen., but paler; the black fascia of the underside narrower; no yellow suffusion beneath near the base ; discal spot of forewings almost obsolete.

Several specimens from Java.

\section{Pingasa latifascia sp. nov.}

Forewings whitish ochreous, mottled all over with pale olive green scales; costa dark greenish grey; first line greenish, forming two larger teeth, and one smaller above the inner margin; discal mark greenish, linear, oblique; second line denticulated, dull greenish, followed by a suffusion of dark green and rust coloured scales; submarginal line paler, denticulated; fringe whitish with blackish blotches at base between veins. Hindwings like forewings, but without basal line. Head, thorax, and abdomen pale whitish ochreous; face with a black bar at top. Underside white, hardly tinged with ochreous along the costa of both wings; with a large blackish oblique cell mark in forewings, and an almost imperceptible one in hindwings; a very broad black marginal fascia, concisely edged internally and touching the hindmargins opposite the cells.

One $\delta$ from Batchian.

Akin to dispensata Wlk.

\section{Pingasa rubicunda sp. nov.}

Forewings ochreous white; costa pale greenish; first line dark green, forming two large and one smaller tooth; discal mark elongated, bent, dark green; second line black, nearly straight for the upper two-thirds, then inclined inwards, throwing out small black teeth along the veins hindwards; from base to this line the whitish ground colour is sparsely dusted with greenish scales; hindmarginal area dull pinkish grey, mottled with paler and mixed with greenish; submarginal line pale, dentated; fringes whitish, suffused in part with pinkish, with an irregularly defined blackish basal line, which swells out more into spots between the veins; inner margin dusted with bright rosy scales. Hindwings like forewings; in the middle of the hindmargin of both wings is an irregular paler blotch. Head, face, thorax, and patagia whitish ochreous; abdomen the same, but suffused down the back with dark fuscous green scales. Underside pure white, suffused with yellowish towards the base, with black cell spot to forewing, and a broad black submarginal fascia, which touches the hindmargins at the anal angles and opposite the cells.

Several examples, alf $\delta \delta$, from the Khasia Hills.

This species comes near rufofasciata Moore, but is distinguished at once by the darker scaling, and the very broad and distinct black fasciae of the underside.

\section{Pingasa subdentata sp. nov.}

Like crenaria Guen.; distinguished by the following points: the external margin of the black fascia of the underside is irregularly dentate; the base of both wings beneath is more largely suffused with yellowish; and the hindwings beneath have a distinct black cell spot, which is absent in the allied forms.

Several examples from S. Celebes. 
Pingasa venusta sp. nov.

Forewings with the central space, which is much constricted, white, dusted especially along the costa and inner margin with ochreous olive scales; basal area and broad marginal field olive yellow, tinged with cinereous and with delicate transverse dark striae; the yellow tint being condensed along the veins, which are almost orange; two transverse lines, very distinct, black; the first at one-third slightly curved and nearly vertical, forming a single tooth inwards above the inner margin; second, before two-thirds, curving inwards, and twice as near the first on inner margin as on costa ; bluntly toothed externally; subterminal line indicated only by a row of strong teeth; the space between it and the second line greyer than the space beyond it to the bindmargin, which is elearer yellow, except at anal angle, where there is a greyish patch ; fringes yellowish, with a dark spot at base between the denticulations. Hindwings with no white central space, the basal two-thirds being entirely suffused with coarse olive and whitish scales; second line blackish, distinctly denticulate, but not nearly so strongly expressed as in the forewing. Head, face, antennae, thorax, and abdomen concolorous with the yellow ground colour of wings. Underside pure white, the basal area largely and evenly suffused with dull yellow ; a broad black submarginal fascia, not touching hindmargin except opposite the cell of the forewings; cell spot of the forewings large, irregularly lunular, showing faintly on the upperside; cell spot of hindwings small, faintly visible above.

Two of from Sikkim, one larger than the other.

Expanse of wings: 46 to $50 \mathrm{~mm}$.

\section{SubFamLy GEOMETRINAE.}

\section{Iotaphora gen. nov.}

Forewings ample, elongate; costa faintly curved; apex rounded; hindmargin rather strongly curved ; anal angle rounded off. Hindwings rather long; hindmargin well rounded, waved; antennae in $\delta$ shortly pectinate for three-fourths; in $q$ thick, simple, minutely subserrulate; palpi short, hardly reaching in front of face, which is rounded ; tongue present. Neuration normal ; discocellulars both angulated, the lower arm very oblique.

Type: Iotaphora iridicolor Butler (Panathia).

\section{Calleremites gen. nov.}

Forewings with costa nearly straight, becoming slightly convex towards apex; hindmargin evenly and rather obliquely curved; inner margin somewhat convex. Hindwings, with hindmargin well rounded, the anal angle produced; inner margin straight; both wings beneath, with the basal area clothed with short furry scaling; palpi stout, ascending, porrect; third joint bent forward, short, and obtuse; tongue present; face rounded, slightly protuberant; antennae ( $\delta$ ) quite simple. Neuration : discocellular of forewings angulated; that of hindwings running throughout obliquely inwards ; cell two-fifths of the length of the wing ; first median nervule at two-thirds, second and third from the lower end of cell ; lower radial of forewings from slightly above the centre of the discocellular; upper radial from top angle of cell; fifth subcostal out of the common stem of the last four at one-third, running into hindmargin some way below apex. In the hindwings the costal curves away from the subcostals, which are shortly stalked.

Type: C. subornata sp. nov. 
Calleremites subornata sp. nov.

Forewings pale olive ochreous, tinged with luteous towards the hindmargin and at the anal angle, with a few fine pale transverse striae; basal half of the wing crossed by a dark fuscous olive fascia, the margins of which are concave, its inner margin running from the costa at one-sixth to the inner margin at one-third, the outer from about the centre of the costa to nearly two-thirds of the inner margin; the fascia is thus twice as broad on costa as on the inner margin, and narrowest below the median vein. Hindwings similar, but the dark olive fascia extends quite to the base; fringes luteous; in the pale outer half of both wings the dark fascia of the underside shows through. Underside quite different; pale drabbish ochreous; base of both wings broadly tinged with bright yellow; a large pear-shaped black cell spot on both wings, and a broad diffuse blackish fascia along the outer half, not reaching the hindmargin nor the costa of the forewings. Face tawny olive; palpi darker; vertex ochreous ; collar and thorax bright yellow ; abdomen worn, probably concolorous with wings.

Expanse of wings: $64 \mathrm{~mm}$.

One of from Sikkim, in the Felder collection.

\section{Aporandria gen. nov.}

Forewings ample; costa straight, convex only before apex, which is subfalcate; hindmargin bowed; anal angle square. Hindwings broad, with the hindmargin entire, rounded, but with a blunt elbow in the middle. Antennae pectinated in both sexes; palpi porrect, twice as long in $q$ as in $\delta$; forehead with a pointed projection below, which in the $q$ is conspicuous and one-third the length of the palpi ; tongue present; legs short ; hind tibiae with four spurs ; scaling dense. Hindwings with a paler, semitransparent patch at the base, the discocellular enlarged and beset with raised scales, and followed by a small round transparent patch. In the hindwings both subcostals, and the second and third median nervules, are on a longish stalk.

Type: Aporandria specularia Guen. (Geometra).

\section{Rhodochlora gen. nov.}

Forewings ample, triangular; costa nearly straight, more convex before apex, which is a little produced, but not acutely; hindmargin obliquely curved; inner angle almost rectangular. Hindwings broad, with hindmargin well rounded, and with slight elbow in middle; antennae $(q)$ simple, but thickened towards base and minutely serrulate; the basal joint somewhat enlarged, and with a minute tooth in front ; palpi long, porrect; tongue present. Neuration normal ; scaling fine and soft ; the hindwings with a semitransparent patch at the base.

Type: $R$. roseipalpis Feld. (Achlora).

The genus is evidently related to Aporandria specularia Guen., from India, which has a similar semitransparent space at the base of the hindwings; but in it the $f$ antennae are subpectinated. The $\delta$ will probably show more definite peculiarities.

\section{Rhodochlora brunneipalpis sp. nov.}

Nearly related to $R$. roseipalpis Feld., from Venezuela, but with fewer markings. Forewings of the same pale apple green, but with the veins yellowish or reddish, especially on the under surface, whereas they remain white in roseipalpis; in this 
last the reddish denticulated exterior line forms a strongly marked erescent just above the inner margin, which is filled up with white succeeded by a reddish blotch of roundish shape, which is partially continued upwards as a reddish shade beyond the exterior line itself. In brunneipalpis, the crescent is much finer, and the red spot beyond hardly perceptible, and not produced; besides which it is decidedly nearer the anal angle than in roseipennis. Hindwings entirely pale green; whereas in roseipennis the pale space at the base is followed by a broad reddish shade; underside of both wings whitish green; the tip of the hindwings brownish; this brown spot is absent in roseipennis; palpi dull red brown. Thorax and abdomen whitish green.

Expanse of wings: $52 \mathrm{~mm}$.

One $q$ from Rio Demerara.

Besides the difference in coloration, there appears to be a slight but appreciable difference in the shape of the wings. In roseipennis the costa of the forewing is straighter; the hindmargin is straighter and more oblique, and the hindwings show the elbow much more plainly.

\section{Pareuchloris gen. nov.}

Distinguished from Euchloris by the $q$ antennae being distinctly pectinated, though sometimes (as in vernaria) shortly so; in the hindwings the hindmargin is more or less distinctly angulated or elbowed in the middle, whereas in Euchloris it is quite round.

Type: Pareuchloris vernaria Linn.

\section{Opisthotia gen. nov.}

Forewings with the costa faintly eurved; apex hardly pointed; hindmargin curved, faintly waved; anal angle distinct. Hindwings with the inner angle rounded, the anal angle produced into a short ear-shaped lobe; hindmargin elbowed at the end of the third median nervule, on each side of which it is concave; antennae of $\delta$ pectinated, the pectinations moderate, even, pubescent; tip filiform; palpi short, hardly reaching in front of face; tongue present; hind tibiae slightly flattened and thickened, with two pairs of short spurs. Neuration normal; sealing fine and sparse ; the surface of the wings, especially on the underside, iridescent.

Type: Opisthotia tumidilinea Moore (Geometra).

\section{Ornithospila gen. nov.}

Forewings ample, triangular; costa straight till just before apex; hindmargin curved, subcrenulate, more distinctly just below apex; anal angle well marked. Hindwings broad, with hindmargin waved, and a blunt but distinct elbow at the end of the third median vein. Antennae ( $\delta$ ) pectinated, the pectinations short, even, and pubescent; tip filiform; palpi porrect, reaching beyond face; tongue present; hind tibiae with two pairs of spurs; scaling fine and dense; discocellular of hindwings biarcuate, marked above with red brown; markings two transverse denticulate deep green lines.

Type: O. avicularia Guen. (Geometra).

The $q$ is not known of any species of this genus, as far as I can ascertain. 


\section{Urospila gen. nor.}

Near to Omithospila Warr., but distinguished in two points; the hindwings have a more prominent projection at the end of the third median nervule, containing a black brown spot as in Urapteryx. The markings consist, not of denticulated green lines, but straight white lines, as in Megalochlora Meyr.

Type: U. lineata Moore (Geometra).

\section{Chloroglyphica gen. nov.}

Forewings with costa straight to the apex; apex itself bent round; hindmargin at first vertical, with two minute crenulations, then straight and oblique to the anal angle, with even a faint indentation between the second and third median veins; anal angle square. Hindwings broad; hindmargin with a distinct tooth in middle; above which it is slightly sinuous, and quite straight below it to the anal angle which forms a right angle. Palpi ( $\delta$ ) stout, porrect, short; third joint quite small; tongue present; antennae of $\delta$ shortly and regularly pectinated; hind tibiae in the only $\delta$ examined with three spurs. Neuration normal; scaling as in Thalassodes, but denser and more varied.

Type: C. variegata Butler (Loxochila).

\section{Paramaxates gen. nov.}

Akin to Dooabia Warr. Forewings with costa arched from base to apex, which is blunt and not produced; hindmargin strongly dentate; two teeth more prominent than the rest, one at the end of the fifth subcostal nervule, projecting beyond the apex, the other at the end of the third median; between these two the margin is lunate; below the middle tooth it is very oblique and deeply dentate. Hindwings with hindmargin deeply dentate, and a longer blunt tooth at end of the third median; antennae, palpi, and legs as in Dooalia ; scaling thick and coarse.

Type: P. vagata Wlk. (Macaria).

Paramaxates vagata Wlk. celebensis subsp. nov.

Wings above more olive green than in either of the two Indian forms; base of the hindwings dull rosy, with black transverse striae; a broad black submarginal fascia on the hindwings. Underside whiter than in the Bhotan form, less so than in that from the Khasia Hills, with the black submarginal fascia of the two wings as in the former. The specimen, a $\mathcal{f}$, is somewhat worn, and an exact comparison is impossible. It is the only $q$ of the species I have seen, all the rest in the Rothschild collection, seventeen in number, being $\delta \delta$. From S. Celebes.

\section{Paramaxates vagata Wlk. khasiana subsp. nov.}

Generally smaller and paler green than in the type form. Underside with the black fasciae very mueh narrower, in some cases reduced to a mere black streak.

Several specimens from the Khasia Hills.

\section{Chlorodontopera albiguttata sp. nov.}

Forewings dull green; basal area paler; first line consisting of small curves, nearly vertical; exterior line dentate, starting from costa at two-thirds, and attaining the inner margin at two-thirds, approaching the first line above the inner margin; 
space between the two lines darker green, especially along the edges of the lines; space beyond the exterior line paler, but gradually darkening again up to the subterminal line, which is represented by a series of dull white lunulate spots; basal line of fringe dark green; fringes pale ochreous, with a darker medial line, and the extremities of the teeth cinereous; a very distinct ovate black cell spot with a pale ochreous centre; hindwings the same. Head, thorax, and abdomen (probably) concolorous with ground colour of wings, but in the type faded ochreous. Underside dark olive green, with the basal line obsolete, but the pale spaces margining the exterior and submarginal lines clear white and very conspicuous; no trace of cell spots in either wing.

Expanse of wings: $38 \mathrm{~mm}$.

One $\&$ from Padang.

A very distinct and pretty species, especially underneath.

Dooabia gen. nov.

Forewings with costa strongly curved from base to apex; apex minutely produced; hindmargin denticulate-crenulate, with a larger, more prominent tooth at the end of the third median nervule, below which the margin is more oblique than above it; anal angle distinct. Hindwings with the hindmargin produced into a very long pointed tooth at the end of the third median nervule, denticulatecrenulate on either side of it; palpi porrect, short; the third joint short, drooping; tongue present; antennae simple in $\delta$; hind tibiae with a pencil of hairs, and two pairs of spurs; scaling fine and thin.

Type: Dooabia viridata Moore (Ennomos).

Agathia diversiformis sp. nov.

Wings pale apple green; forewings with the costa dull whitish grey, as in codina Swinh., a deep purplish black basal spot, which does not reach above the median, but is much more prolonged along the inner margin than that in codina; an irregular, nearly vertical olive grey fascia at one-third, and beyond the middle a broad olive grey fascia occupying nearly the whole outer half of the wing, connected by a similar coloured blotch with the hindmargin above the elbow, above and below which is a narrow green space; the inner edge of this broad fascia is deeply indented between the second and third medians, and on the submedian fold is joined to the first narrow fascia; some small green spots occur in the middle of the broad fascia, and a green space below the costa; fringe greyish white, dark grey at the elbow. Hindwings with the extreme base brown; the inner margin, a blotch on it near the base, and a very broad fascia, olive grey; this fascia contains near its inner edge a curved dark streak from the inner margin, and some black linear dashes on the veins; anal angle purplish grey; fringe whitish grey at the interior angle, thence to anal angle dark purplish, preceded by a broadish purple black line. Face pale below, cinereous purple above, as is the vertex; collar green; thorax purplish; abdomen green mottled with olive grey. Underside pale whitish green, with a broad purplish grey submarginal fascia, of which the inner half is the darker, the outer half having a smeared look, and connected with outer margin by a darker purplish streak; fringe of the hindwings purplish black.

Expanse of wings: $50 \mathrm{~mm}$.

One $\delta$ from Darjiling. 
Distinguished from all other species by the outline of the wings. In the forewings the hindmargin is bluntly angled at the end of the third median, above which it is vertical, and below it oblique. In the hindwings the hindmargin is perfectly straight from anal angle to the end of the second subcostal, except for a small projecting tooth at the end of the third median.

\section{Lophochlora gen. nov.}

Forewings elongated; costa gradually convex; apex prominent; hindmargin with the upper half nearly vertical, then suddenly oblique and waved; inner margin somewhat convex. Hindwings narrow, with the hindmargin deeply indented between two prominent teeth at end of the lower subcostal and third median. Forehead flat; palpi short; antennae of $\delta$ simple; hind tibiae rather thickened, with four spurs; abdomen with suberect crests of hairs on segments 3,4 , and 5 .

Type: L. cristifera Wlk. (Thalera).

\section{Lophocrita gen. nov.}

This genus, which in other respects resembles Lophochlora Warr., is characterised by the subserrate ciliated antennae of the $\delta$, and the recurved crests of hairs on the back of the abdominal segments.

Type: Lophocrita undifera Wlk. (Thalera).

\section{Berta (?) discolor sp. nov.}

Wings rather dark sandy ochreous (? green when fresh), with the lines consisting of a series of disconnected white lunate spots; fringe concolorous, as are the thorax and abdomen; vertex and shaft of antennae white; underside entirely pinkish white.

Expanse of wings: $24 \mathrm{~mm}$.

One of from Padang.

\section{Lasiochlora gen. nov.}

Forewings with costa slightly shouldered at base, and then faintly curved to apex, which is pointed, and subfaleate; hindmargin curved and faintly waved; anal angle rounded. Hindwings with hindmargin waved, and a slight tooth in the middle at the end of the third median nervule. Palpi porrect, short in both sexes; antennae pectinated in both sexes; tongue weak; scaling rather coarse and lax. Neuration: cell half as long as wing; discocellular angulated, the lower arm oblique. Forewings: first median at five-sixths, second at seven-eighths, third from lower end of cell; radials as usual; last four subcostals on common stem; first subcostal anastomosing with costal. Hindwings: costal anastomosing with subcostal for half the length of cell, just as in the Hydriomeninae; subcostals both from end of cell; medians as in forewings.

Type: Lasiochlora diducta Wlk. (Geometra).

\section{Agraptochlora gen. nov.}

Forewings slightly convex at base of costa and before apex, the costa between straight, or even slightly indented; apex blunt, slightly produced; hindmargin curved, with a slight bend in the middle, below which it is more oblique; anal angle 
distinct. Hindwings with hindmargin well rounded, slightly waved. Antennae ( $\uparrow$ ) simple; palpi excessively short, not half reaching front of face; tongue small and weak; abdomen crested above. Neuration normal; scaling close and somewhat coarse; wings without markings.

Type: Agraptochlora subaspersa sp. nov.

It is rather unsatisfactory to form a new genus upon the description of $q q$ only ; but the general appearance of the two species which I refer to this genus, coupled with the extreme shortness and weakness of the palpi and tongue, seem enough to warrant it.

\section{Agraptochlora marginata sp. nov.}

Wings deep green, without markings; fringe dull reddish, with a broad dull yellowish basal line; costa of forewings ochreous yellow. Underside pale gilded green, with the fringe as above; base of costa of forewings reddish; head and thorax green; abdomen ochreous; face, legs, and palpi red; antennae brownish ochreous.

Expanse of wings : $36 \mathrm{~mm}$.

One $\&$ from Tiapang.

\section{Agraptochlora subaspersa sp. nor.}

Wings pale apple green, without markings; costa of forewings ochreous; fringe with dark brown interrupted base line, and (apparently, as the fringe is worn) a central dark line as well; vertex, thorax, and base of abdomen green; rest of abdomen ochreous dusted with reddish brown; face and palpi red brown. Underside pale yellowish green, sparsely dusted with reddish brown striae.

Expanse of wings : $48 \mathrm{~mm}$.

One $\&$ from S. Africa.

\section{Eucyclodes gen. nov.}

Forewings with costa quite straight till just at apex; apex blunt; hindmargin well rounded; anal angle indistinct. Hindwings with full-rounded hindmargin; anal angle somewhat produced and squared. Antennae of $\delta$ pectinated; palpi rather short, third joint minute; forehead with a small triangular horny projection above; hind tibiae of $\delta$ with four spurs and a pencil of hairs. In the hindwings the two subcostals and two last medians are on a short footstalk; scaling dense.

Type: Eucyclodes buprestaria Guen. (Phorodesma).

\section{Euloxia gen. nov.}

Forewings elongate, costa faintly curved from base to apex; apex distinct, but not acute; hindmargin obliquely curved; anal angle distinct, but rounded. Hindwings elongate, with rounded hindmargin. Antennae of $\delta$ broadly pectinated to the tip; of $q$ simple; palpi very short, not reaching beyond face; hind tibiae with two pairs of spurs placed near together; scaling fine and smooth; markings consist of two oblique sinuous lines. Neuration: first median in both wings at five-sixths, second and third both together from lower end of cell ; two subeostals of hindwing on a short footstalk.

Type: Euloxia fugitivaria Guen. (Iodis).

A small Australian genus of weak-winged insects. 


\section{Leucoglyphica gen. nov.}

Forewings with costa strongly arched from base to apex; apex prominent; hindmargin obliquely curved, faintly elbowed in the middle; anal angle well marked. Hindwings kite-shaped, with a prominent angle at end of third median nervule; anal angle decided; internal angle rounded off; antennae of $q$ filiform; of $\delta$ shortly and thickly pectinated along the basal half; apical half filiform; palpi porrect, short, and thick in $\delta$; longer and more slender in $q$; tongue present; hind tibiae in $\delta$ with four short spurs. Neuration normal; discocellular of both wings marked with an oblique white line.

\section{Type: Leucoglyphica pallescens Hmpsn. (Geometra).}

\section{Mixolophia gen. nov.}

Forewings with costa nearly straight, shouldered at the extreme base, and convex before apex ; apex prominent ; hindmargin oblique, hardly curved, subcrenulate; anal angle prominent. Hindwings kite-shaped, with subcrenulate hindmargin; a prominent blunt tooth at the end of the third median nervule; anal angle square. Antennae (ठ) minutely subserrate and pubescent; palpi short, porrect, rostriform; tongue present; basal segments of abdomen with three curved tufts of hair, the central one black; anal segment prolonged. Neuration normal; cell two-fifths of the length of the wings.

Type: $M$. ochrolauta sp. nov.

\section{Mixolophia ochrolauta sp. nov.}

Wings dull green. Forewings with costa spotted narrowly with dark fuscous and pale; a narrow exterior ochreous line curved outwards, and slightly but irregularly wavy to the third median nervule, thence running parallel to hindmargin; anal angle occupied by a large ochreous blotch, which extends upwards to the apex as a narrow streak along the hindmargin; apical veins ochreous; a dark curved line at base of fringes, with a minute dark dot at the end of each vein, the dots becoming larger and the line obsolescent towards the anal angle; fringe ochreous, tinged with grey. Hindwings the same, but the basal green four-fifths pear-shaped; the ochreous line much broader, the ochreous space at the anal angle more developed, and another smaller one at the internal angle; an oval white, raised discal spot. Abdomen ochreous, tinged with greenish grey basewards; the first and third tufts ochreous, the central one blackish; thorax dull green; face reddish; vertex white. Underside pale whitish green, with the ochreous line showing through.

Expanse of wings: $32 \mathrm{~mm}$.

One $\delta$ from Bhutan.

\section{Ochrognesia gen. nov.}

Forewings with costa mainly straight, convex from base, and before apex; hindmargin obliquely curved. Hindwings narrow, oblong; hindmargin with a blunt elbow at the end of the third median nervule; inner margin cut away. Antennae of $\delta$ simple; palpi quite short, slightly ascending; terminal joint invisible; tongue present; hind tibiae with four spurs. Neuration normal; cell two-fifths of the length of the wings.

Type: O. difficta Wlk. (Comibaena).

Walker's type of $O$. difficta was from North China. Bremer's Phorodesma gratiosaria from East Siberia is the same insect. 
0steosema gen. nov.

Forewings broad, triangular; costa faintly curved throughout; more convex before apex, which is blunt; hindmargin not oblique, slightly bowed; anal angle well marked. Hindwings broad, with hindmargin rounded, and a slight angulation in the middle at the end of third median nervule; anal angle widened and produced; antennae of $\delta$ short, with regular short curved ciliations, which decrease gradually towards the apex; palpi short, feeble, not reaching beyond face (in $\delta$ ); terminal joint short, drooping. Underside of abdomen furry; hind tibiae with two pairs of spurs.

Type: O. sanguilineata Moore (Comibaena).

\section{Thalerura marginata sp. nov.}

Of the same size, and shape, and colour as T. acutissima Wlk., but the fringe, instead of being yellow, is iron grey, without a dark basal line, and with white dots at the ends of the veins; the exterior line is distinct, and denticulate, not broken up into spots; the yellow costa is only spotted with darker just before the apex. Underside pale bluish white, with no trace of cinereous suffusion on either wing.

One $\delta$ from Bhutan.

\section{Thalerura prasina sp. nov.}

Wings deep grass green; costa of forewing ochreous, dusted with dark atoms; fringe yellow with a dark purple basal line, interrupted by yellow dots at the end of the veins, and with dark marks opposite these dots; no distinct transverse lines, but traces of whitish spots on the veins; hindwings the same. Thorax green; abdomen cinereous reddish; face reddish with the lower part white; vertex and shaft of antennae white. Underside pale bluish white, with the fringe and marginal line as above.

Expanse of wings: $40 \mathrm{~mm}$.

One $\delta$ from Bhutan. Distinguished by the bright green ground colour and absence of markings.

\section{Gelasma irregularis sp. nov.}

Wings dull greyish green, covered with a multitude of small white sinuous strigae; first line vertical, sinuous; second line oblique, denticulate and sinuous; the intervening space darker green, still darker close to each line; the first line edged internally, the second externally with whitish; a pale green discal ocellus edged with darker; hindwings the same; fringes concolorous. Thorax and abdomen cinereous green; vertex whitish. Underside dull greenish white.

Expanse of wings: $38 \mathrm{~mm}$.

One of from Bhutan.

Akin to glaucaria Wlk., but the exterior line much more irregular, and nearer the hindmargin. 
Hemistola Warr. (Pr. Z. S., 1893, p. 353).

The $q$ in this genus has pectinated antennae, like the $\delta$.

\section{Hemithea rubrifrons sp. nov.}

The same size and colour, and with similar markings to $H$. distinctaria Wlk., but the face, palpi, antennae, legs, and costa of forewings are brick red; the costa spotted with black; vertex, thorax, and basal segments of abdomen green; rest of abdomen pinkish grey.

One $\&$ from Bhutan.

\section{SubFamily ASTHENINAE.}

\section{Acolutha gen. nov.}

This genus is closely related to Agnibesa Moore, but is at once separable by the $\delta$ antennae, which are pectinated.

Type: Acolutha pictaria Moore (Emmelesia).

Laciniodes gen. nov.

Forewings ample, triangular; costa straight, but convex at the base and before apex, which is square; hindmargin curved, with a slight elbow in centre. Hindwings with a similar slight elbow, subcrenulate, with a larger and deeper excavation opposite to the cell. Antennae simple but slightly pubescent in $\delta$; palpi short, porrect, blunt; thickly but laxly scaled; tongue present; hind tibiae with four spurs. The transverse markings form a lace-like pattern in the marginal half of the wings.

Type: Laciniodes plurilinearia Moore (Somatina).

\section{Zola gen. nov.}

Forewings elongate; costa slightly shouldered near the base, and convex before apex, which is slightly produced; hindmargin curved, more obliquely before the anal angle, which is nevertheless well marked. Hindwings elongate, with the hindmargin rather irregularly rounded. Forehead flat, vertical, with some projecting scales below; palpi triangular, drooping, hairy; antennae of $\delta$ serrate, pubescent, rather thick; of $q$ filiform, slender; hind tibiae with four spurs. Neuration: first median at four-fifths, second just before end, in both wings; last subcostal of forewings from just before top end of cell; first four on common stem; in the hindwings two subcostals on short common stem.

Type: Zola terranea Butler (Ozola).

\section{Orthoclydon gen, nov.}

Forewings elongate, triangular; costa scarcely arched; apex prominent; hindmargin oblique. Hindwings triangular, the angles rounded; hindmargin nearly straight. Palpi very short; tongue present; antennae of $q$ simple; of $\delta$ plumose; hind tibiae with four spurs. Neuration: cell not quite half as long as wing; first median at three-fourths, second a little before the end, third from the end; the 
median being bent slightly inwards at the origin of each; lower radial as usual; upper radial and last four subcostals on a common stem from the upper end of cell ; the radial parting almost at once; the second and fifth, the third and fourth from the same point; first subcostal free, rising long before the end of cell. Hindwings with costal anastomosing with subcostal almost to end of cell; the two subcostals on a short common stem; medians as in forewings; scaling smooth and glossy; markings a series of oblique, parallel lines.

Type: Orthoclydon praefectata Wlk. (Acidalia).

\section{Poecilasthena gen. nov.}

Forewings elongate, triangular; costa nearly straight, curved slightly at base, and before apex; apex blunt; hindmargin obliquely curved; anal angle distinet. Hindwings kite-shaped, with a short, but distinct, blunt projection in middle of hindmargin, on either side of which it is nearly straight; wings semidiaphanous, traversed by a series of oblique, sinuous lines. Palpi very short; tongue present; antennae simple in both sexes; hind tibiae of $\delta$ with four spurs. Neuration, as in Asthena.

Type: Poecilasthena pulchraria Dbld. (Acidalia).

Phrudoplaga gen. nov.

Forewings elongate; costa slightly curved at base and before apex, which is rounded; hindmargin obliquely eurved. Hindwings narrow, with the hindmargin rounded, and subcrenulate or wavy. Palpi very short; tongue present; antennae (f) with the edges of the joints slightly prominent; minutely pubescent; wings thickly scaled, with pairs of undulating metallic lines. Neuration: cell hardly one-third the length of wing. Forewings with first median at five-sixths, second and third close together from lower end of cell ; radials as usual ; five subcostals, as far as can be seen without denudation, on a common stem from just before end of cell; no areole discernible. Hindwings with the two subcostals and last two medians on a common stalk; costal anastomosing with subcostal to near the end of cell.

Type: Phrudoplaga argentifilata Feld. (Acidalia).

\section{Epicyme atrostrigata sp. nov.}

Pale grey brown, with a slight reddish tint; crossed by wavy blackish streaks, which form a basal, median, and submarginal band; the outside streak of the basal band, and the inside one of the other two being most distinct; a black cell spot, and row of marginal black dots; hindwings the same, but with no basal band. Head, thorax, and abdomen concolorous, the latter with two rows of black dorsal spots. The black undulating streaks are very variable, and in some specimens are quite absent, the streaks being merely a little darker than the ground colour.

Expanse of wings: $\delta, 20 \mathrm{~mm}$; $\uparrow, 22$ to $24 \mathrm{~mm}$.

A good series from Queensland.

\section{Atopophysa gen. nov.}

Wings ample; forewings with costa arched at base and before apex; hindmargin obliquely curved; hindwings with rounded hindmargin. Forehead 
produced below; palpi porreet, rostriform, forming a shelf in same plane as forehead; tongue present; antennae simple, thicker in $\delta$ than $q$; hind tibiae with four spurs. Forewings of $\delta$ with a long oval bladdery fovea on the submedian nervure close to base, the nervure apparently dividing and forming the edges of the fovea, which is margined with a layer of flat scales on the under surface.

Type: Atopophysa indistincta Butler (Scotosia).

\section{Eschatarchia gen. nov.}

Allied to Chalyboclydon Warr.; but the frontwings are more falcate; the hindmargin more strongly elbowed in the middle; the hindwings with hindmargin subcrenulate and produced into a decided angle in the middle. The neuration also differs; the cells are equally short; but in Eschatarchia in both wings the median is bent inwards at its extremity, and the second median nervule rises from the bend just before the end of the cell. In Chalyboclydon, the median nervure is straight; both the second and third median nervules rise from the end in the forewings, and are short stalked in the hindwings.

Type: Eschatarchia lineata sp. nov.

\section{Eschatarchia lineata sp. nov.}

ठ. Forewings stone colour, pinkish tinged, dusted with fuscous; costa brownish ; two or three indistinct brown eurved lines near the base; two oblique parallel brown lines beyond the cell dot; a curved reddish brown thick line from just before apex to the hindmargin above the elbow, and from below the elbow to the anal angle; fringes dark grey, with a dark brown basal line. Hindwings with two parallel brown lines across the centre; two less distinct and more curved towards the hindmargin; a thick reddish brown shade along the hindmargin, thinner above the elbow than below. Thorax and abdomen concolorous; the latter with two rows of dark dorsal spots; thorax in front tinged with brownish; face brown; vertex white. Underside dull stone colour with traces of darker suffusion near the base, and of dull cross lines.

Expanse of wings: $32 \mathrm{~mm}$.!

One of from Japan.

Placotome gen. nov.

Closely allied to Polynesia Swinh., but distinguished by the peculiar excision of the forewings in the $\delta$ (? and $q$ ). The costa suddenly bulges out at three-fourths, and the edge is bent over, while the rest of the costa appears to have been cut straight off; two of the subcostals run into this projecting part, and other two obliquely into the apex.

Type: Placotome truncapex Swinh. (Polynesia).

\section{Pseudasthena ochracea sp. nov.}

ठ. Forewings yellow, crossed by a series of undulating, partly denticulated, orange or fuscous orange lines, forming a more or less distinct basal patch, central fascia, and submarginal fascia; a darker diffuse horizontal subcostal streak; when the orange is mixed with fuscous, the lower part of the central fascia is wholly filled up with fuscous; the centre of the fascia often bears a fuscous streak, which is sometimes extended to the hindmargin; and the marginal dots are then 
also fuscous. Hindwings the same, with a darker basal streak, a spot on inner margin, and a streak from anal angle to the centre of the hindmargin; a small black cell spot in each wing. Underside dull straw colour, with the markings greyish fuscous. Head, thorax, and abdomen yellow, mottled with orange.

Expanse of wings: $24 \mathrm{~mm}$.

A long series, all $\delta \delta$, from the Khasia Hills. Two specimens, also $\delta \delta$, from the Feld. collection, labelled Sikkim, are as much as 28 to $30 \mathrm{~mm}$. in size, but cannot be separated.

\section{Pseudasthena (?) plumbacea sp. nov.}

Wings dull liver colour, with a pinkish tinge, and slightly glossy; crossed by a series of darker sinuous, curved lines; four vertical near the base, before the discal mark, which is blackish, linear, and vertical ; five beyond, these being curved outwards in the upper half of the wing, and slightly wavy; between the fourth and fifth of these, opposite the cell, is a pale yellow spot; fringe and extreme hindmargin yellow, with dark dashes along the base of the fringe. Hindwings the same, but with no yellow spot; and the fringe wholly yellow, with no darker dashes except two in the centre of the hindmargin. Head, face, thorax, and abdomen concolorous with wings; frontlet, and shaft of antennae white. Underside duller throughout.

Expanse of wings : $26 \mathrm{~mm}$.

One $\delta$ from New Guinea.

I place the species provisionally in Pseudasthena, from its resemblance to grataria Wlk.

\section{Psilocambogia hyriaria sp. nov.}

Forewings bright yellow, with the costa and four irregular bands dull blood red. Hindwings the same, the costa not red; the basal bands are rarely well defined, except on the inner margin of the hindwings; the exterior and submarginal bands are edged irregularly; the fourth is a narrow marginal streak.

Expanse of wings : 12 to $16 \mathrm{~mm}$.

Two of from Feld. collection without locality; one $q$ from St. George's, smaller than the two $\delta \delta$.

\section{Omphacodes gen. nov.}

Forewings elongate, twice as long as broad ; costa straight ; apex blunt, rounded; hindmargin oblique, hardly curved; anal angle obtuse. Hindwings elongate, hindmargin rounded. Palpi very short; antennae of $\delta$ either simple, thick, or with short serrations, which are finely pubescent; tongue present; hind tibiae of $\delta$ with four spurs. Forewings green; hindwings white. Neuration: cell half as long as wing; first median at five-sixths, second close before end of cell, third from end; discocellulars angulated; lower radial from the upper half, as in the Geometrinae. Hindwings with the costal anastomosing with subcostal to near the end of cell; two subcostals on a long stalk; radial and medians as in forewings.

Type: Omphacodes directa Wlk. (Nemoria?). 


\section{SubFAMILY TRICHOPTERYGINAE.}

Phthonoloba gen. nov.

Forewings with costa curved throughout; hindmargin obliquely curved; apex rectangular, not acute; anal angle rounded; inner margin two-thirds as long as costa. Hindwings of ordinary size, with rounded hindmargin. Abdomen of $\delta$ very long, the two middle segments abnormally lengthened, as in Tatosoma Butler, from New Zealand; legs long and slender; hind tibiae with one pair of spurs; antennae thick and simple, annulated above; palpi long, rostriform, as in Remodes. Neuration: forewings, first median nervule at half; second and third from end of cell, running concave to each other ; lower radial from centre of transverse vein ; accessory cell large; first subcostal nervule from before apex of accessory cell; second, third, and fourth on a common stem from the end; fifth a little below the outer angle; upper radial from above the upper angle of cell ; first median at two-thirds, second just before the end, third from the end.

Type: Phthonoloba decussata Moore (Sauris).

The diagnosis of this genus was accidentally omitted in Proceedings Zoological Society, 1893, p. 363.

\section{Phthonoloba curvistriga sp. nov.}

Like the Indian species, $P$. decussata Moore, in coloration, but differing in having the edges of the central fascia and the lines next adjacent, formed of symmetrical simple curves, whereas in decussata each curve is irregularly broken and angulated. The hindwings are much darker, brownish grey.

A pair from Gunong Ijau.

\section{Remodes cinerosa.}

? Remodes remodesaria Hmpsn. (I. L. H., viii., p. 31 (part), Nilgiris).

These Nilgiri specimens are all larger than Walker's Ceylon examples of remodesaria, much less green, being thickly sprinkled with dark grey; they all show a clear pale sinuous subterminal fascia, like the Australian vetustata Wlk., to which they seem nearest allied. The $\delta \delta$ have the cleft in the forewings evident, and the hind tibiae are armed with a thick tuft of black hairs.

Two $\delta \delta$, one $q$.

\section{Sauris Guen.}

This genus differs from Remodes Guen., in having the hindwings of the $\delta$ small, but not distorted, with a small indistinct lobe at the base. The third median nervule is wanting in the hindwings.

\section{Holorista gen. nov.}

Allied to Remodes Guen., with which it agrees in all respects, except that it is without the incision in the hindmargin of the forewings of the $\delta$, which characterises that genus.

Type: H. proboscidaria Wlk. (Sauris). 
Isosauris gen. nov.

Near Pacrophylla Blanch., but differing in the following points :-antennae in both sexes simple, not thickened; hindwings in $\delta$ without additional inner lobe; hindwings in both sexes with one nervule absent (probably the third median), the radial starting from the transverse vein halfway between the centre and lower end of cell; in this respect, it probably approaches Rhopalodes Guen., though Guenée says that in that genus it is the independent that is wanting.

Type: Isosauris hastigera Butler (Oporabia).

Toxopaltes gen. nov.

Distinguished from Tomopteryx Philippi, in having no cleft and additional lobe in the hindwings; but the hindmargin of the hindwings is produced in the middle as a sharp point, with the margin on either side curving away, just as in Holorista Warr., from India.

Type: Toxopaltes botulata Feld. (Tomopteryx).

Triptila gen. nov.

Distinguished from Rhopalodes Guen. by the presence of a distinct radial to the hindwing, which Guenée expressly states to be absent in that genus; distinguished from Tomopteryx Philippi by the absence of the cleft in the hindwings; characterised positively by the possession of a very large superincumbent lobe on the hindwings.

Type: Triptila virescens Philippi (Tomopteryx).

\section{Subfamly EUCESTINAE.}

Carsia perelegans sp. nov.

Allied to plagiata Linn., which occurs also in Afghanistan and India; but the transverse bands are finer and paler; the whole ground colour is more pinky; in particular, the exterior line which forms the outer edge of the middle field is much less sharply angulated. There is no trace of dark or black at the rise of the lines on the costa, nor in the apical streak.

Expanse of wings : $34 \mathrm{~mm}$.

Several examples from Japan.

Docirava affinis (?) sp. nov.

Closely allied to $D$. vastata Wlk., from India, of which it may be merely a local form, but the difference is constant. The two pale lines across the forewings are more slender; the central fascia formed by these lines is not edged within the lines by a broadly darker shade.

A long series from Central China and two from Japan.

\section{Lissopsis gen. nov.}

A South American genus, allied to Marmopteryx Pack., from North America, and to Siona, of Europe. Distinguished by the very fine, smooth scaling, and especially by the antennae of the $\delta$, which are densely and shortly serrate.

Type: Lissopsis columba Butler (Siona). 


\section{SubFamily URAPTERYGINAE.}

\section{Euctenurapteryx gen. nov.}

A genus of much stouter build than Urapteryx Leach; more thickly scaled. Antennae of $\delta$ deeply pectinated; of $q$ bluntly serrated. Hindwings with a short blunt tail, the hindmargin on either side of it being irregularly waved.

Type: Euctenurapteryx maculicaudaria Motsch. (Acaena).

\section{Tristrophis obtusicauda sp. nov.}

Of the same size and shape as T. veneris Butler, but with the usual markings of Urapteryx-viz., two broadish, transverse, brown grey bands, with a smaller cell dash between them, and two small reddish dots before the abbreviated tail; but the antennae, as in veneris, are laminated.

Several examples from Japan.

\section{Urapteryx fulvinervis sp. nov.}

Like U.podaliviata Guen., but smaller; the apical third of the forewings varied with a number of transverse rusty fuscous striae, but without any third line, as in podaliriata. The hindwings are still more different; the tail is only half as long as in podaliviata; there is no trace of the pale grey curved line which in that species precedes the second rusty line; along the inner margin there runs a distinct rusty line from base to outer margin, and the three median nervules are all rusty; the tail spot is blackish, not red, and the numerous ochreous fuscous striae that fill the space before the tail extend upwards towards the inner angle. The stripes throughout are redder than in podaliriata.

Expanse of wings : $40 \mathrm{~mm}$.

One of from Padang.

Brachurapteryx gen. nov.

Differs from the Palaearetic genus Uraptery $x$ Leach, in that the tail of the hindwings is reduced to a mere angular projection; the antennae are thicker, and the position and direction of the lines are dissimilar.

Type: Brachurapteryx breviaria Hüb. (Therinia).

\section{Callurapteryx gen. nov.}

Like Brachurapteryx Warr., a new-world genus, but distinguished from it by having the antennae of the $\delta$ pectinated. The character of the markings, however, is quite enough to distinguish it from Euctenurapteryx, the East Asiatic genus, which also has pectinated antennae in the $\delta$.

Type: C. saturniaria H. S. (Urapteryx).

Phrygionis Hüb. (Verz., p. 307).

At p. 291 of the Verzeichniss Hübner gives Eulepidotis with three species-v1z., ilyrias Cram., politia Cram., and alabastraria Hüb. Of these politia Cram. has been removed to Nepheloleuca; Eulepidotis must therefore stand for ilyrias and alabastraria. At p. 307, under Phrygionis, we have also three species-viz, cultaria Hüb., corinna Cram., and julianaria Stoll. Of these the last two are congeneric 
with the two above-mentioned species of Eulepidotis. Phrygionis is therefore left with cultaria Hüb. for its type, and both Guenée's Byssodes and H. S.'s Eulepidotus must sink.

\section{Galactopteryx gen. nov.}

Forewings triangular; costa nearly straight, convex just before apex, which is blunt; hindmargin slightly curved, with a scarcely perceptible elbow at the end of the third median nervule. Hindwings kite-shaped, with a short tooth, or merely a prominence in the middle of the hindmargin. Palpi upcurved in front of face, the terminal joint very minute; antennae of $q$ simple, minutely subserrulate, of $\delta$ armed with fascicles of cilia; tongue present; hind tibiae of $\delta$ with four spurs. Neuration normal; scaling thick and glossy, white. Closely related to Gonorthus Butler, but distinguished by the $\delta$ antennae, which in Gonorthus are strongly pectinated.

Type: Galactopteryx penicillata sp. nov.

\section{Galactopteryx curvistriga sp. nov.}

Wings milk white ; like $G$. penicillata, but differing as follows : costa of forewings not yellow, but pure white, as are the fringes; lines of the forewing ochreous, not grey, running from inner margin before anal angle to the costa, not erect, but parallel throughout to the hindmargin. Hindwings the same; the second line forms no spot on the inner margin. Underside wholly white. Thorax and abdomen white, only antennae and face appearing slightly luteous.

Expanse of wings : $36 \mathrm{~mm}$.

One $\delta$ from Rio Janeiro.

The hindwings in this species have only a slight prominence instead of an angle in the middle of the hindmargin.

\section{Galactopteryx (?) nigricornis sp. nov.}

Wings and body all milk white, the extreme base of the costa of forewings alone being black; collar, face, base of antennae, and outside of palpi also black; antennae themselves luteous.

Expanse of wings : 36 to $38 \mathrm{~mm}$.

Two $q q$ from the Felder collection, one of which is marked Bogota.

In the absence of the $\delta$ I have queried the genus, though I have little doubt that the species belongs here.

\section{Galactopteryx penicillata sp. nov.}

Wings milk white; costa of forewings narrowly yellowish, sometimes with a dark dot or two faintly visible; from the inner margin before the anal angle rise two erect fuscous grey streaks, which hardly reach beyond the middle of the wing, both towards the middle becoming broken into two or three smaller streaks. Hindwings the same, but both streaks more distinct, and nearly parallel to hindmargin; the outer one on the inner margin forms a dark spot; fringes of both wings pale ochreous. Thorax and abdomen white; face, antennae, palpi, and inside of legs luteous; top of head, base of antennae, and knees black. Underside pure white.

A o without locality given; a $q$ from the Felder collection marked Cayenne. Expanse of wings : ठ , $36 \mathrm{~mm}$; $\uparrow, 34 \mathrm{~mm}$. 
Pityeja pura sp. nov.

Ground colour pure white, not orange; markings the same as in histrionaria H. S., but rather more distinct. In the hindwings the orange is confined to the marginal area, and the black markings in it are plainer.

Both sexes, without locality, from the Felder collection.

Druce treats this as a mere form of histrionaria, and speaks of the orange tint as variable; but in all the examples in the Rothschild collection the orange is similarly restricted, while in all the specimens of histrionaria that I have seen the whole hindwing is orange.

\section{Thinopteryx citrina sp. nov.}

Like praetoraria Feld., from the Philippines, with which it has hitherto been confounded; in size it is decidedly smaller. The whole of the under surface of both wings is clouded with dull grey blotches. In the forewings the first line is nearly straight, and reaches the inner margin well before the middle; whereas in praetoraria this line is very distinctly bent outwards in its lower half, and reaches the inner margin about in the middle.

Common in Sikkim and North India.

Thinopteryx praetoraria Feld. (Reise Nov., Pl. CXXII., fig. 13, q).

The type, from the Felder collection, is a very large example; a $q$, from the Philippines, quite distinct from the pale Indian form which has been hitherto mistaken for it. It may be distinguished at once from all the other forms by the shape of its basal line, which is not, as in the rest, straight, but sinuous. The underside is pure clear yellow, with only the submarginal fascia dark; in the pale yellow form from North India, citrina Warr., the whole under surface is varied with dull grey blotches. In the Rothschild collection is also a $\delta$ from $\mathrm{S}$. Celebes, which agrees well with the Philippines type.

\section{Pareumelea gen. nov.}

Forewings ample; costa strongly convex; apex blunt; hindmargin obliquely curved; in $\delta$ with a slight elbow opposite the cell; hindwings rounded. (In the $\delta$ of one species the forewings have two slight concavities, and a prominence below the apex ; the hindmargin thence cut straight off to the anal angle.) Palpi ascending: second joint thickly scaled; terminal joint smaller, distinct, smooth; antennae of o subserrate beneath, and shortly ciliated; neither the antennae nor the legs nearly so long as in Eumelea. Hindwings without a radial; hind tibiae somewhat thickened.

Type: Pareumelea fimbriata Cram.

\section{SubFamily SCARDAMIINAE.}

\section{Angeronopsis gen. nov.}

Forewings ample; costa nearly straight; apex blunt, not produced; hindmargin strongly eurved; anal angle well marked. Hindwings with full rounded hindmargin; $\delta$ antennae three-fourths as long as forewings, filiform, minutely subdentate beneath, with very short fine bristles; these in $q$ hardly perceptible; palpi thick, hairy beneath, slightly upcurved to face; terminal joint invisible; tongue present. Neuration as in Palyas.

Type: A. pertextaria Hüb. (Hypoplectis). 


\section{Hyphenophora gen. nov.}

Forewings ample; costa weakly arched; apex blunt, almost rounded; hindmargin entire, curved. Hindwings with hindmargin entire, well rounded. Antennae simple in both sexes, long; palpi porrect; tongue present; forehead slightly protuberant, rounded; hind tibiae of $\delta$ with four spurs, the last pair quite short; legs and abdomen long. Neuration: forewings, cell barely half the length of wing; discocellular obtusely angulated; first median nervule from three-fifths; second and third from end of cell, the third close behind the second; lower radial from angle of discocellular; upper from upper end of cell ; last three subcostals on a common stem from shortly before end of cell, the subcostal nervure at its origin being slightly bent inwards; the fourth subcostal branch runs into the apex, and the third very short into the costal margin; first and second subcostals on a common stem, which anastomoses with the costal. Hindwings with the median nervules as in forewings, the two subcostals answering to the second and third medians; scaling fine and close; both wings with a submarginal line of metallic spots shaped like a hyphen.

Type: H. perlimbata Guen. (Palyas).

\section{Hyphenophora palumbata sp. nov.}

Wings pale dove colour; costa dotted with blackish; a black distinct cell spot; submarginal metallic line as in perlimbata Guen.; on the inner margin of forewings before the submarginal line is an abbreviated pale yellowish oblique fascia form marking, and a shorter one on the costa of the hindwings just below it. Head, abdomen, and underside, as well as fringes, concolorous.

Expanse of wings: $46 \mathrm{~mm}$.

One of from R. Niger.

Ballantiophora innotata sp. nov.

+. Extremely near B. gibbiferata Guen. Costa of forewings more narrowly and paler gilded; both wings without any darker shading before the hindmargins, and without the black spots at base of fringes; fringe of forewings golden; of hindwings pure white; the spots forming the transverse lines are smaller and more regularly placed; towards the hindmargins of both wings are some scattered very fine gilded atoms, not strigae, as in gibbiferata.

One $q$ from Petropolis.

\section{Leuciris gen. nov.}

Hübner, in the Verzeichniss, p. 307, gives under Chrysocestis, auraria (= aura Cram.) 2962, and concinnaria Hüb. 2963. Of these concinnaria was mentioned and figured first, in the Zuträge, i., p. 32, No. 100, figs. 199, 200 ; auraria occurring in iii., p. 39, No. 296, figs. 591, 592. But the two species are not congeneric. Consequently concinnaria must be taken as the type of Chrysocestis, to the exclusion of Guenée's subsequent Molybdophora; aura Cram. thus becomes the type of Palyas Guen. The two species fimbriaria and fimbrialis Stoll., though called Chrysocestis by Walker, have no right whatever to that name, and a new one becomes necessary. Herrich Schaeffer's Chrysotaenia cannot be employed, as the two species referred by him to that genus are cultrata Hüb., and formosante Cram. 


\section{Stenoleuca gen. nov.}

Near Leuciris Warr., but distinguished by the shape of the forewings, which are hardly a third as wide as the hindwings, much elongated; costa arched and convex in its outer half; apex prolonged, but broad, and bluntly rounded; hindmargin very oblique; inner margin only two-thirds as long as costa. Hindwings very broad, quite as broad as long, with hindmargin elliptically rounded. Palpi exceedingly minute; antennae of o pubescent, as in fimbrialis Stoll.

Type: $S$. distorta sp. nov.

\section{Stenoleuca distorta sp. nov.}

Forewings pearly white, with the costa brilliantly golden to beyond the middle, thence to apex luteous; hind border luteous, straight, edged internally by a dark shaded, silvery margined, metallic line; this line runs from the costa before the apex to the inner margin before the anal angle, and as the hindmargin of the wing is very oblique, the luteous border of the wing is broader on the costa than at the inner margin; a row of gilded lozenge-shaped spots towards the outside of the luteous border, the lower seven in a direct straight line, the uppermost at an angle with the rest; a dark indistinct cell-streak; fringes white, Hindwings like forewings. Thorax and abdomen white; collar, face, and antennae luteous. Underside dull white, with all the markings showing dull; costa of forewings in basal half bronzy fuscous.

Expanse of wings: $20 \mathrm{~mm}$.

One $\delta$.

\section{Subfamly PALYADINAE.}

This subfamily is characterised by the absence of the frenulum.

\section{Argyroplutodes gen. nov.}

Distinguished from the allied forms by the elongated forewings with quite round apex and hindmargin, and by the transverse lines of silver-studded spots across them. The character of the markings recalls Plutodes.

Type: A. limboguttata Felder (Palyas).

\section{Argyrotome gen. nov.}

Forewings with costa gradually curved; apex blunt; hindmargin curved. Hindwings with hindmargin fully rounded, entire. Antennae simple in both sexes; palpi porrect, short; tongue present; hind tibiae of $\delta$ with four spurs. Neuration normal; scaling glossy. Distinguished from its allies by having a large ocelloid marking on discocellular of forewings, and no metallic ocellus on hindwings.

Type: A. mira Oberth. (Ephyra).

\section{Argyrotome notata sp. nov.}

Wings pure white, with a few scattered brown seales; the lines indicated by brown spots; the first by three spots, a small one on the subcostal, and two larger ones on the median and submedian, the former at the origin of the first median nervule; second line curved, gently denticulate, forming spots on the veins, and 
almost obsolete between them; a large irregularly rounded ocellus on the discocellular, which is prolonged as a brown blotch, nearly to touch the exterior line; marginal line and spots between the veins red brown. Hindwings the same, but without cell spot, and all the spots less distinct. Face, palpi, and antennae brown; all else, and underside of wings white.

Expanse of wings : $34 \mathrm{~mm}$.

One $f$ from Petropolis.

This must be allied to Ophthalmophora alba Druce.

\section{Ophthalmophora Guen.}

For the majority of the species placed by Guenée in his genus of this name, Hübner's earlier term Opisthoxia will have priority. These all have, as far as is at present known, simple antennae in the $\delta$; but for alectaria, the $\delta$ of which has well pectinated antennae, Guenée's generic name may fairly be retained.

\section{Subfamily PLUTODINAE.}

Archiplutodes gen. nov.

Closely allied to Plutodes Guen., and Micronissa Swinh., having, like those genera, uniseriate pectinated antennae in both sexes. The hindwings are fully rounded. In markings it is abundantly distinct; these consist of a series of dark transverse undulating streaks, and a large discal spot.

Type: A. prasina Swinh. (Asthena).

\section{SubFamily DEILINIINAE.}

\section{Bapta distans sp. nov.}

Very close to $B$. mytylata Guen. (= margarita Moore) from India; as in that species the fringe is pure white with no trace of a dark basal line; but the wings are not so iridescent. It may be distinguished by the course of the second line, which is not only further from the hindmargin, but runs exactly parallel to it on both wings, except on costa of forewings where it is evidently recurved basewards. In the hindwings of mytylata this line approaches the hindmargin towards the anal angle; abdomen ( $q$ ) dark grey.

One $q$ from Japan.

\section{Bapta foedata sp. nov.}

Like B. temerata in shape, but decidedly smaller in size; both wings thickly dusted with dirty grey scales; an indistinct darker exterior line, formed by the agglomeration of these scales, and running parallel throughout to the hindmargin. Forewings with a small black cell dot; fringes white with a fine fuscous basal line. Underside shining white, the base of the forewings suffused with cinereous.

One $q$ from Japan.

Bapta ochrilinea sp. nov.

Of the same size and shape as B. temerata, shining white, sparsely sprinkled with small black atoms, and with a small and indistinct dark discal spot in each wing. No distinct trace of a transverse line. Basal line of fringes pale rust colour, fine and concise; extreme edge of costa of forewings yellowish. Underside of both wings pure white.

One $\&$ from "China," without more precise locality. 
Bapta undilinea sp. nov.

Forewings and hindwings silky white, sometimes with a faint indication of a dark cell dot; forewings with costa narrowly dark; a fine pale fuscous line runs at about three-fourths parallel to the hindmargin of both wings, and is therefore curved on the hindwings. In one specimen the space between this line and the hindmargin is beset with dark seales, which are arranged somewhat in a fascia. Head, thorax, and abdomen silky white; face red brown. Underside wholly silky white.

Expanse of wings : $30 \mathrm{~mm}$.

Three $\delta \delta$ from Novo Friborgo, Petropolis, and S. Paolo respectively.

\section{Deilinia (?) punctata sp. nov.}

Forewings chalk white, with four rows of dark spots, the first three fuscous, the last, marginal, black; these rows are parallel to the hindmargin, but the costal spot of each row is very much nearer the base than the next; that of the third row forms an oblique costal dash; and the first of the marginal black row is on the costa before the apex; the fourth spot of this last row is very small, and both the third and fourth are wanting in the other rows. Hindwings the same, but with only three rows, the basal row being absent; a large, blackish cell spot in each wing; fringes white. Head, thorax, abdomen, and underside all white. Underside of wings white, with cell spots and marginal row of spots also marked, the others only showing through; costa of forewings at the extreme base black, and the basal region of forewings freckled with fuscous.

Expanse of wings : $30 \mathrm{~mm}$.

One $\&$ from Japan.

In the absence of the $\delta$ the position of this species must not be considered quite certain; but though differing somewhat in the character of the markings from other species of the genus, I am fairly sure that it belongs here.

Eugonobapta gen. nov.

Forewings elongate; costa curved throughout; apex blunt; hindmargin curved obliquely. Hindwings with the hindmargin bluntly produced in the middle. Palpi very short, not reaching front of face; tongue present; antennae simple, thick, laminated; hind tibiae somewhat thickened, with four spurs; scaling thin and loose. Neuration : cell more than half the length of wing; first median of forewings at two-thirds, second close before end, third from end of cell; median nervure slightly, subcostal nervure very much, bent inwards, towards the end; lower radial from the middle, upper from the top of the discocellular: fifth subcostal from the bend in the subcostal nervure, closely approximated to the stem of the other four, which rises still further basewards. Hindwings, medians as in forewings; first subcostal from before end of cell.

Type: Eugonobapta nivosaria Guen. (Acidalia).

\section{Leucetaera gen, nor.}

Near Bapta Stph. Forewings with costa straight, curved only at base, and before apex, which is slightly produced, but blunt; hindmargin bowed, with a perceptible bulge in the centre; anal angle well marked. Hindwings with the hindmargin rounded but bulging in the centre. Antennae simple in both sexes, 
not so stout as in Bapta; palpi considerably larger and more developed; upraised and closely appressed to face; second joint thick and well scaled; third minute; tongue present; markings, an oblique line from before apex of forewings to just before anal angle of hindwings.

Type: Leucetcera inamata Wlk. (Acidalia).

Physostegania gen. nov.

Like Stegania Guen. in most respects, but the forewings have at the base an exaggerated fovea, which reaches from the median vein across the submedian fold to the submedian vein, the upper half being thickened externally and clothed with a small tuft of scales beneath; the palpi are shortly rostriform, and porrect, reaching in front of face.

Type: Physostegania pustularia Guen. (Stegania).

Heterostegane aurantiaca sp. nov.

Wings bright ochreous, irrorated with dull orange. Forewings with costa dark brown; an indistinct nearly straight dark brown basal line at one-third, a second at three-fourths more distinct, running into the anal angle, and connected by similarcoloured horizontal streaks with the hindmargin, opposite the cell and above the anal angle; between the two darker lines is a still more indistinct denticulated orange line; fringe bright ochreous. Hindwings the same, Head, face, thorax, and abdomen ochreous, mottled with orange; the collar darker. Underside duller, with the lines marked in brown.

Expanse of wings : $24 \mathrm{~mm}$.

Several $\delta$, from the Khasia Hills.

\section{Heterostegane hyriaria sp. nov.}

Wings pale pinkish ochreous, sparsely dusted with ferruginous red; costa of forewings diffusely darker; a curved inner line at one-third, hardly reaching the inner margin; an irregular distinct red brown line at five-sixths, connected with hindmargin along costa, and opposite the cell; fringe concolorous, with a ferruginous basal line, and a ferruginous dash opposite the cell. Hindwings with two indistinet curved central rust coloured lines, and a distinct ferruginous basal fringe line. Head, thorax, and abdomen concolorous with wings. Underside pale straw colour, with all the markings dark brown, and much mottled with dark brown scales, more especially near the base of the forewings.

Expanse of wings : $24 \mathrm{~mm}$.

Several examples from Japan.

\section{Heterostegane quadrilineata sp. nov.}

Wings pale wood colour, sparsely sprinkled with dark ferruginous scales, and with the lines all purplish ferruginous; a short mark close to the base; first line at one-sixth, angulated below costa, then vertical ; second before the middle, nearly vertical, broader on costa ; third just beyond the middle, finer and zigzag; fourth submarginal, irregularly vertical, and bent before the anal angle, connected with hindmargin by ferruginous streaks opposite the cell and above the anal angle; hindmargin with an additional dark ferruginous line; fringe concolorous, mottled 
with dark ferruginous. The ferruginous dusting is thickest along the veins, and along the submedian fold forms a continuous horizontal line. Hindwings the same, with all the veins towards the hindmargin ferruginous. Head, face, thorax, and abdomen concolorous, mottled and streaked with ferruginous. Underside of wings paler and duller, with the markings also duller.

Expanse of wings: $22 \mathrm{~mm}$.

Three $\delta \delta$, two from Gunong Ijau, and one from Borneo.

Ninodes gen. nov.

Akin to Peratophyga Warr., but with normal neuration-viz., the lower radial from the centre of the discocellular, the upper from the upper angle of cell. Like Peratophyga with a strongly marked fovea at base of forewings. Palpi quite short and weak, porrect, but hardly reaching front of face; antennae of $\delta$ simply pubescent ; legs short; hind tibiae with four spurs; scaling much coarser and laxer than in Peratophyga, the lines metallic.

Type: Ninodes splendens Butler (Ephyra).

Peratophyga gen. nov.

Forewings with costa straight till shortly before apex, which is blunt; hindmargin well rounded, oblique just at anal angle, which is rounded. Hindwings with hindmargin rounded. Palpi upraised in front of face, short; the third joint minute; tongue present; antennae of $\delta$ subserrate with curled cilia; hind tibiae of $\delta$ long with two pairs of spurs, placed close together. Neuration: forewings, the two radials on a short common stem rising from the upper angle of cell; last four subcostals on common stem; first subcostal free. Forewings with a strongly marked hyaline fovea on the submedian fold.

Type: Peratophyga aerata Moore (Acidalia).

\section{Xenagia gen. nov.}

Forewings with costa more curved than in Parasynegia Warr., the apex rather more prominent; hindmargin entire, obliquely curved. Hindwings round, not elongated, with entire hindmargin. Palpi shorter than in Parasynegia, especially the third joint; forehead produced; antennae well pectinated. Neuration: first median in both wings at three-fourths of the cell; scaling close and thick.

Type: Xenagia vitticostata Wlk. (Hyperythra).

\section{Xenagia vitticostata.}

Hyperythra vitticostata Wlk., xxvi., p. 1497. ? Type in B. M. . Darjiling.

" $\quad$ Moore, Pr. Z.S., 1867, p. 619

, " , Swinh., Cat., No. 3155 .

Synegia infixaria

Butler, I. L. H., vi., p. 75, Pl. CXVIII., fig. 4 (nec. Wlk.)

Swinh., Cat., No. 3587 .

I think the above synonymy will be found correct. How Mr. Butler came to confound Walker's Caberodes infixaria from Venezuela with this species I am at a loss to conjecture; the description is utterly unlike. This same Darjiling insect has likewise been identified with camptogrammaria Guen., from Borneo, which, however, seems to me rather a Synegia, akin to, if not identical with, Walker's imitaria from Ceylon. 
Borbachodes gen. nov.

Resembles Borbacha Moore, having like that genus unipectinate antennae in the $\delta$, but characterised by the presence of a small bladdery pustule between the submedian vein and the inner margin at about one-fifth from the base.

Type: B. pardalis Feld. (Anisodes).

Syntaracta gen. nov.

Allied to Synegia Guen., but the pectinations of the $\delta$ antennae are considerably more developed, and the wings are wholly without trace of the peculiar pustule which forms the distinguishing characteristic of that genus. The markings are also much more complex.

Type: Syntaracta hadassa Butler (Anisodes).

\section{Syntaracta aemula sp. nov.}

Wings pale ochreous, quite sparsely mottled with dull ferruginous; costa slightly darker, especially at base, and metallic ; lines obsolete in their upper half, or nearly so, edged below with dark brown; the second line in the middle connected by a thick dark brown blotch with the hindmargin; a smaller, dark brown, subapical blotch; submarginal line ferruginous; fringe pale with dark black brown dashes at the base between the veins, which are followed by darker spaces in the fringe. Hindwings the same; the first line showing only as a brown blotch on the inner margin; the subapical blotch larger than in the forewings. In one $f$ this blotch is continued across the submarginal and second band so as to unite with the inner margin, and in the forewings the lower half of the space between the second and submarginal lines is dark greyish fuscous. Underside paler and duller. In the markings of the head, thorax, and abdomen this species resembles imitaria Wlk., but I can hardly consider it a form of that species; it is always smaller and paler; and the obsolescence of the lines towards the costa forms a good distinguishing point.

One $\delta$, two $q$, fro $m$ Ceylon.

\section{Syntaracta obscura sp. nov.}

Invariably larger and duller than examples of imitaria Wlk., from Ceylon; costa of forewings dark fuscous, but not metallic; the two lines both thicker; the dark submarginal fascia always distinct. Underside in particular much duller, with the markings very inconspicuous.

One $\delta$, four $q q$, from the Nilgiris.

\section{Syntaracta ocellata sp. nov.}

Ground colour bright yellowish ochreous, mottled with orange, with the markings fuscous grey; costa fuscous grey; basal line curved, thick, fuscous grey, with three black dots on its inside edge, on the subcostal, median, and submedian veins respectively; second line, like first, from three-fourths of costa to two-thirds of inner margin, with dark spots on its outer edge on all the veins, making it appear denticulated; a dark fuscous irregular submarginal fascia, followed by a pale submarginal line; hindmargin with three small dark fuscous patches; fringe mottled, fuscous and bright ochreous, with a row of small dark dots between the veins at the base. Hindwings the same; a small blackish 
cell spot in each wing. A suffused form occurs, in this as in other species of the genus, in which the anal region of both wings, and the inner margins partially, are suffused with fuscous grey; in all examples, a small pale ocelloid spot appears in the middle of the submarginal line, on either side of which is a dark fuscous blotch. Head, thorax, and abdomen bright ochreous, mottled with orange and fuscous grey, like the wings. Underside paler, more straw colour, with all the markings dark fuscous, and proportionally more distinct.

Expanse of wings: $46 \mathrm{~mm}$.

One $\delta$, three $q+$, from Gunong Ijau.

\section{Syntaracta omissa sp. nov.}

Wings pale ochreous, with ochreous fuscous mottlings, and fasciae; first line darker fuscous, twice curved, preceded by a paler, but not always distinct, fascia of unmottled ground colour; second line darker fuscous, denticulated, followed by a similar space of unmottled ground colour; the first line is followed, and the second preceded, by a shade of ochreous fuscous; a submarginal, and marginal, sinuous edged fascia of the same ochreous fuscous, between which the submarginal line is more or less visible as a subcontinuous row of pale spots; fringe ochreous fuscous, mottled with lighter, with no darker basal line; costa dotted with dark fuscous, but not itself darker, and scarcely metallic except at the extreme base. Hindwings the same; a distinct dark fuscous cell spot in each wing. Head, thorax, and abdomen concolorous with wings. Underside the same, but paler.

Expanse of wings: $\delta$ \& 32 to $50 \mathrm{~mm}$.

The largest of the Japanese species, and quite distinct from hadassa Butler.

Syntaracta varians sp. nov. and aberr. lineata.

Of five $q q$ from Gunong Ijau, only two are alike; one, the lightest, has a pale yellow ground colour with ferruginous freckles and markings, and the costa slightly darker; this comes nearest imitaria Wlk. from Ceylon, or rather between it and Synegia botydaria Guen.; in two others the markings are greyish fuscous, and the ferruginous dots less conspicuous; in the fourth the ground colour is straw colour, the whole surface mottled and variegated with blackish fuscous atoms, the two lines being denticulated and edged with blackish; while in the fifth all denticulation is gone; the costa is black brown; the two lines have become black brown straight markings, and connected with the hindmargin by two black brown streaks in each wing. These vary also in size, the first being about as large as imitaria, the others smaller, the fifth being the least of all. Not one of the five can fairly be placed with the Ceylon imitaria, and I see no reason for not considering them to form a species (or, at all events, a race) apart. Warr.

Five $q f$ from Gunong Ijau. The fifth I propose to call aberr. lineata

Parasynegia Warr. (Pr. Z. S., 1893, p. 413).

Forewings ample, elongate; costa all but straight, slightly curved at base, and convex just before apex, which is blunt; hindmargin obliquely curved; anal angle distinct. Hindwings broad, with both angles somewhat produced; hindmargin subcrenulate, more distinctly so towards the apex. Forewings with fovea near 
base; and with a very much enlarged flat scaly retinaculum, which reaches below the median vein. Antennae in $\delta$ fully pectinated, the tip filiform; in \& simple; palpi porrect, ascending, rather stout; second joint long and thickly scaled; third joint shortly button-shaped, deflexed; tongue present; hindlegs long; tibiae with two pairs of spurs, not thickened. Neuration: cell hardly half the length of wing; first median from one-half, second just before end, third from the end of cell ; radials normal ; last four subcostals on a common stem. Hindwings with two subcostals from upper angle of cell.

Type: Parasynegia pluristriaria Moore (Anisodes).

As the diagnosis referred to above is incomplete, I give this fuller one now.

\section{Parasynegia macularia sp. nov.}

Wings yellow, thickly mottled with bright reddish orange; forewings with costa dark fuscous; first line represented by an agglomeration of the orange speckles, except on costa and inner margin, where there can be seen a short dark fuscous spot, or streak; second line represented by a broad oblique irregular fascia, blackish at its edges, containing a horizontal blackish streak along the upper radial, and a roundish olive grey patch between the first and third medians, below which it is deflected inwards, and forms a dark irregularly triangular patch along the inner margin from the first line to beyond the middle; the streak on the upper radial is continued irregularly towards the hindmargin and apex; and the grey blotch is also connected by a fuscous shade with the hindmargin; fringe yellow, chequered with darker, with small fuscous dots at the base, at the ends of the veins. Hindwings with a broadish fuscous basal streak; traces of two irregular, sinuous, central lines, and an irregular submarginal fuscous fascia, which forms a blotch on the costa before apex, and some larger fuscous blotches in centre of hindmargin; both wings with distinct black cell dot. Head, thorax, and abdomen yellow, very much mottled with bright reddish orange. Face, tips of palpi, and collar all bright orange. Underside dull straw colour, with the markings and mottlings fuscous grey.

Expanse of wings: $50 \mathrm{~mm}$.

One $\delta$ from Sikkim, in the Feld. collection.

Parasynegia purpurascens sp. nov.

Wings pale yellow, with dull purple or blood red markings and suffusion; forewings with basal half more or less covered with dull red striae, which are congregated at about one-third, so as to form a curved basal line; a broad curved dull red fascia beyond middle connected by two irregular and similar coloured blotches with the hindmargin, one towards the apex, the second below the middle; fringe yellow, slightly mottled with reddish. Hindwings with the base dull red, and a similar band along hindmargin from apex to anal angle; centre of wing occupied by a reddish fascia, consisting of four smaller maculate fasciae; both wings with a small black cell spot. Head, thorax, and abdomen yellowish, mottled with reddish. Underside paler and duller, the markings greyish fuscous, not reddish.

Expanse of wings: $28 \mathrm{~mm}$.

One of, from Ichang, in very poor condition. 


\section{Parasynegia submissa sp. nov.}

Wings yellowish ochreous, speckled with dull ferruginous and fuscous; lines of forewings diffuse and indistinct ; first near base, angulated below costa ; seeond thick, diffuse, from two-thirds of costa, below which it is incurved, to one-half the inner margin, connected with hindmargin twice, by an oblique irregular patch opposite the cell, which runs up into the apex, and by a broader patch between the second and third medians; fringe yellow, chequered with fuscous at end of veins; a small black cell spot. Hindwings with a fuscous basal band; an irregular finer one before middle, containing in its sinus a distinct black cell spot; two more rusty fine denticulated lines beyond, and an irregular fuscous shade from apex to anal angle, forming a blotch in the middle; fringe as in forewings. Head, thorax, and abdomen concolorous, and mottled with ferruginous. Underside duller, with all the markings reproduced in fuscous; the cell dots black.

Expanse of wings: $32 \mathrm{~mm}$.

One $\&$ from the Khasia Hills. Intermediate between lidderdalii Butler and erythre Hampson.

\section{SubFamily BRACCINAE.}

Automolodes gen. nov.

Wings ample, less elongated than in Milionia ; costa of forewings nearly straight, apex blunt; hindmargin slightly curved, much less oblique than in Milionia. Hindwings with hindmargin subcrenulate. Antennae simple in both sexes, hardly pubescent in $\delta$; palpi short; hind tibiae rather swollen. Neuration: cell hardly half as long as wing; in Milionia it is decidedly longer; the median and subcostal nervules not bent in at their ends, the last two median nervules and the two subcostals in the hindwings rising together from the end of the cell. The whole neuration is weaker; the sealing velvety and non-metallic.

Type: Automolodes vacuna Druce (Bociraza).

\section{Panaethia atramentaria sp. nov.}

Wings deep purplish black, with a very indistinct paler purplish curved streak towards the hindmargin ; veins also indistinctly purplish. Hindwings with an additional purplish band near the base. Underside wholly dull black. Head, thorax, and legs dull black; last five segments of abdomen deep yellow.

ठ f. Expanse of wings: $50 \mathrm{~mm}$.

Five examples from Engano.

\section{Craspedosis undulosa sp. nov.}

Wings slaty black. Forewings with a dull pale streak from the centre of the hase; a distinct white blotch beyond middle, not touching costa; its inner edge straight and vertical for two-thirds, then oblique outwards; its outer edge waved, oblique outwards for two-thirds, then oblique inwards; subterminal line whitish blue, beginning below the costa as a strongly zigzag streak, and ending as a sinuous thin line at anal angle. Hindwings with basal area black, distinctly divided off from the white central area, which is broad, and projects outwards in the centre, as two small teeth; subterminal line bluish white, waved, entire; last two segments of 
abdomen yellow above. Underside like upper, but the subterminal lines only indicated on the inner margins.

Expanse of wings: $56 \mathrm{~mm}$.

One $\delta$ from South Celebes.

\section{Bursada concinna sp. nov.}

Closely allied to B. hieroglyphica Wlk. = vestigiata Snell., but brighter coloured, with all the black markings narrower and neater.

One example from the Felder collection, from the Philippines.

\section{Stenele Wlk.}

Wings ample. Forewings: costa nearly straight, convex before apex, which is rounded and blunt; hindmargin obliquely eurved. Hindwings with hindmargin rounded. Palpi weak, horizontally porrect; third joint drooping; tongue present; antennae in $\delta$ fully pectinated; in $q$ also pectinated, but shortly; hind tibiae with four short spurs. Neuration : cell two-thirds as long as wing; discocellular straight, or slightly curved. Forewings: first median from two-thirds, second from seveneighths, third from lower end of cell ; lower radial from centre of discocellular, upper radial from upper angle of cell ; last four subcostals on joint stem from before end of cell; first subcostal free. Hindwings with costal straight; subcostal arched at base, and approaching costal near base; two subcostal nervules from end of cell ; medians as in forewing.

Type: Stenele translata Wlk. of only.

\section{Stenele obsoleta sp. nov.}

Forewings deep coppery red, with the costal and apical one-third black, the edge of the latter much as in S. translata Wlk., showing a quadrate spot on the discocellular; the three pale spots also as in translata Wlk., but the lower pair smaller ; subcostal vein not blackened. Hindwings with a narrow irregular black border, which throws out four long teeth along the costal vein, the two subcostal nervules, and the first median; a narrow linear tooth along the second median, and a blunt triangular one along the third; instead of a spot, only a faint horizontal dark dash across the discocellular. Antennae black; face and vertex white; thorax and abdomen above dull reddish; sides of abdomen greyish black. Underside like upper.

Expanse of wings : $56 \mathrm{~mm}$.

One $\delta$ from South America, without further locality.

\section{Hyalostenele gen. nov.}

Forewings elongate, narrow; costa straight till shortly before apex, which is bluntly rounded; hindmargin very obliquely curved; anal angle rounded off. Hindwings elongate; inner angle bluntly rounded; inner half of hindmargin nearly straight. Antennae of $\delta$ pectinated; palpi porrect, rather long, very slender, the joints distinct; tongue present; eyes large; hind tibiae with four short spurs; scaling sparse; the wings semidiaphanous. Neuration: forewings, cell more than half the length of wing, its margins inclined inwards towards the end ; first median from onehalf, second from seven-eighths, the median itself inclining inwards from its origin; third from the end; lower radial from centre of discocellular, curving downwards; 
upper radial from top end of cell; first subcostal at three-fourths, second at seveneighths, the first anastomosing with the costal and the second; common stem of the other three subcostals rising halfway between second and end; the subcostal nervure bent inwards at its origin. Hindwings: costal approximated to subcostal for some distance; two subcostals on a rather long stem; first median at one-half, second just before the end, the median nervure being bent inwards at its origin; third median from the end; fold of the cell produced as a false vein, which in one species is curved upwards and joins the lower subeostal, and in the other is curved downwards, and reaches the hindmargin close to the third median.

Type: Hyalostenele lutescens Butler (Stenele).

\section{Hyalostenele oleagina sp. nov.}

Wings pale oily yellow, semidiaphanous. Forewings with the costa rather broadly deep black; apical half smoky black, containing three oblong elliptical transparent blotches beyond the cell, separated only by the two radials, and a series of six white spots lying in a curve that runs parallel to the hindmargin, the top four of which decrease in size from the uppermost one, and the two at the bottom are largest; base of the inner margin smoky black. Hindwings like forewings, with a broad costal, and a still broader hindmarginal black border, the latter containing five white spots. Head, thorax, and abdomen black; inner orbit of eyes and a spot on each side of thorax white; tongue yellow ; legs black. Underside of abdomen yellowish; underside of wings like upper.

Expanse of wings: $60 \mathrm{~mm}$.

One $\delta$ from Colombia.

\section{Agirpa gen. nov.}

Girpa Wlk. (xxxi., p. 209 ; nom. praeoc., ef. Wlk., xv., p. 1849).

The hindwings have no true radial; the antennae of the $f$ are pectinated, but more shortly than in the $\delta$; the costal and first subcostal of forewings are united from the base.

\section{Subfamly ABRAXINAE.}

\section{Zerenidae Auct.}

Cistidia Hüb. (Verz., p. 174).

Cramer's figure of Phal. stratonice exactly depicts the species called Vithor agrionides by Butler, except that the antennae (of the $\delta$ ) are represented as pectinated ; and that this was not a mistake of the artist is proved by the text, where Cramer expressly calls them, "plumacées." But there can be little doubt that the antennae affixed to the specimen figured were artificial. In the Felder collection there are several old specimens-some of them marked as Cramer's-in which a plumelet of a bird's feather has been attached to do duty for the lost antenna. If the plate in question is examined carefully the resemblance of the antennae of stratonice, as there depicted, to such a plumelet, is apparent at once. The antennae are really club-shaped, and blunt at the apex, without any pubescence; in Halthia, though swollen towards the apex, they end in a point, and the shaft is visibly pubescent. 


\section{Halthia couaggaria Guen.}

The fact of Guenée's querying the species as from the East Indies will account for its non-recognition by all the authors who subsequently renamed it. There can be no doubt that Guenée's description refers to the form called Eurymede by Motschulsky, that being the $\delta$ of Eurypyle Menétr. In this Amur and Japan form, as also in Felder's interruptaria, the two large white blotches which form the central fascia of the forewings, are never separated, but always coalescent, and the corresponding fascia of the hindwing is always broad, and has its two edges parallel. In the usual Chinese form represented by Walker's lithosiaria, and in examples from Thibet, the two blotches of the forewings are always separated by the confluence of the black from either side, and in the hindwing the fascia is sinuous, narrow, and sometimes almost or quite obsolete. In both forms the $q f$, as a rule, show more white than the $\delta \delta$. The name should be erased from Swinhoe's Catalogue of Indian Moths. I have said above that Felder's interruptaria agrees with the Amur and Japan forms, rather than with the Chinese. A word with regard to this is necessary. In the W. E. M., 1862, p. 39, the type is described as a $\delta$, and it is added, "This species does not seem rare on the mountains of the province: Tsekiang." On Felder's type label on the insect, Tsekiang is also given as locality ; but above the large type label is a smaller one containing the word Japan. Now at the head of the article in the W.E.M., p. 22, after speaking of the insects received from China, the Felders say, "we add a few insects sent by Dr. Siebold from Japan." It seems to me, therefore, permissible to doubt whether the insect said to be from Tsekiang, and made the type of interruptaria Feld., really came from that place; it is quite possible that examples of the two forms came from both places, and that the type label referring to an insect from one locality was inadvertently placed on the pin of an insect from the other. Moreover, the description agrees well with the Chinese form lithosiaria Wlk., but does not agree with the particular insect marked as type by Felder, and figured in the Novara Reise.

\section{Omophyseta gen. nov.}

Forewings with costa slightly curved, more strongly at apex; apex blunt; hindmargin obliquely curved. Hindwings with hindmargin rounded. Palpi very short and weak; antennae of $\delta$ finely pubescent; hind tibiae thickened with four short spurs; hindwings with a very well marked shoulder near the base of the costa. Neuration: cell more than half the length of wing; first median at three-fourths, second shortly before angle of cell, third from the angle; radials as usual; first subcostal nervule represented by an oblique bar from the second to the costal ; third, fourth, and fifth on a common stem from close before upper angle of cell; second connected by a short oblique bar with the stem of the third and fourth, just after the origin of the fifth.

Type: Omophyseta triseriaria H. S.

\section{Omophyseta albiplaga sp. nov.}

Forewings black; in the $\delta$ with two white spots near; the base separated by a black one; in the $q$ the black shading predominates to such an extent that only two small white dots are visible, one close to the base, the other, wedge-shaped, at base of the cell; a large oblong white blotch in the cell, and another below it between the 
median and submedian; a still larger white blotch in the disc beyond the cell, which in the $\delta$ is round externally with a small black indentation on its inner edge; while in the $q$ it is broken up into three oblong blotches, the centre much the largest, by the black scales on the third median nervule and upper radial ; a subterminal series of seven oblong white spots in the $\delta$, much smaller, except the lowest, in the $q$; the $\delta$ has also a thin curved white line above the lowest spot, which is wanting in the $q$. Hindwings white with a broad black margin, containing six squarish white spots, which are likewise much reduced in the $q$; the extreme base and the costa black; in the $q$ a blackish blotch on the interior margin, and another above the end of cell, with the veins spotted with black between them. Head and face yellow; thorax black spotted with yellow; base of patagia yellow, their tips black; abdomen yellow, with black rings, and black spots between the segments. Underside like upper, but the black duller. The wings of the $q$ are broader and darker altogether than those of the $\delta$; in the $q$ the hindmargin of the forewing is convex, in the $\delta$ straight.

Expanse of wings:,$+ 60 \mathrm{~mm}$; $\delta, 50 \mathrm{~mm}$.

Three specimens from South Celebes.

\section{Percnia confusa sp. nov.}

Forewings white, slightly tinged with yellowish towards the base; markings consisting of grey spots and blotches, sometimes confluent, sometimes distinct; costa at base grey tinged, with three oblique blotches, tending to form interrupted lines across wing, but broken in the middle; a round discal spot, in the $q$ separate, in the $\delta$ united with a central costal bloteh; exterior line indicated by an irregularly geminated curved series of grey spots, more or less confluent, and broader on costa and inner margin; hindmargin and fringes grey, with a white indentation in the middle; the lower half in the $\&$ less confluent. Hindwings the same, but the whole basal half white. Underside like upper, but the grey markings rather larger. Face ochreous; thorax and abdomen ochreous, spotted with black; the former partially suffused with yellowish.

Expanse of wings: $52 \mathrm{~mm}$.

One $\delta$, one $q$, from India, without exact locality.

Metabraxas clerica Butler inconfusa Warr. subsp. nov.

Two $\delta \delta$ in the Rothschild collection: one from Chang-yang, the other from Thibet, deserve to be separated as a variety. In them the exterior double row of spots is distinct throughout, not running into one another, or suffused; while in the hindwings the intermediate series of the three rows of spots along the margin, which in the type form from Japan is always more or less irregular, and blotched, consists of regular spots, placed precisely in the intervals between those of the outer and inner rows; and in the Thibet specimen is not only very faint above, but quite absent on the under surface. Both specimens have in consequence a much neater and regular appearance than the type form, which is always blurred. They, in fact, approach the Indian species, regularis Warr.

\section{Xenoplia gen. nov.}

Intermediate between Metabraxas Butler and Percnia Guen.; distinguished by the $\delta$ antennae, which are armed with short oblique fascicles of cilia, which are themselves also finely ciliated, or pubescent laterally.

Type: $X$. foraria Guen. (Perenia). 


\section{Xenoplia subfumida sp. nov.}

Forewings chalk white; suffused with smoky grey; with five rows of smoky grey spots; the first near the base; the second before the middle; the third sinuous beyond the middle; the fourth subterminal parallel to the hindmargin; the fifth marginal at the base of the fringes; the spots of the third and fourth series are more or less confluent; between the fourth and fifth, and along the costa, are a lot of small grey flecks; fringes pure white. Hindwing white, without any smoky suffusion, with three rows of spots, one central, curved; the second subterminal, the third as in the forewings marginal; a small dark grey cell spot in each wing. Thorax and abdomen white with black spots. Underside the same, but duller.

Expanse of wings: $44 \mathrm{~mm}$.

One $\delta$ from the Khasia Hills, and a $\&$ from Darjiling.

\section{Pogonopygia gen. nov.}

Forewings of $q$ broader than those of $\delta$; costa gradually curved before apex, which is rounded; hindmargin in $f$ simply oblique; in the $\delta$ the forewings are bluntly subfalcate, and the lower two-thirds of the hindmargin slightly concave, and altogether much more oblique than in $q$; hindwings rounded. Antennae filiform; in $\delta$ slightly pubescent; palpi short, stumpy; the third joint not distinguishable; tongue present; thorax hairy beneath; hind tibiae of $\delta$ short, swollen, with two pairs of spurs, and a brush of dark hairs; abdomen of $\delta$ beneath with large basal, subapical, and anal tufts of hairs. Neuration normal.

Type: Pogonopygia khasiana Swinhoe (Abraxas).

\section{Dilophodes gen. nov.}

Akin to Pogonopygia Warr., but without the exaggerated anal tufts of that genus; a pair of dark tufts of hair beneath at the base of the middle legs, and a lateral one behind the third pair; abdomen beneath with segmental rings of hair; forewings shaped alike in both sexes; antennae of $\delta$ with very distinct fine ciliations; hind tibiae swollen, with two pairs of spurs, and a short brush of hairs at the top.

Type: Dilophodes elegans Butler (Abraxas).

\section{Heterabraxas gen. nov.}

Forewings ample; costa strongly and evenly arched from base to apex; apex blunt; hindmargin slightly curved, not very oblique; anal angle well marked. Hindwings broad, their hindmargin well rounded; a small projection at the end of the first subcostal nervule. Antennae pectinated in both sexes; shorter in the $q$; palpi thick, short, hardly reaching beyond face, terminal joint indistinguishable; tongue present; abdomen of $q$ short, stout.

Neuration as in Abraxas.

Type: Heterabraxas spontaneata Wlk. (Abraxas). 


\section{Abraxas illuminata sp. nov.}

Basal patch and anal blotch large and diffuse; the latter not broadened on the inner margin of the hindwings; markings dull leaden grey; a series of costal spots, often confluent into irregular blotches; an irregular grey blotch at end of cell (in which the discocellular generally is left white), with one or two grey blotches obliquely below it; hindmargin dark grey, with still darker spots, and a dark grey blotch in the middle; apex with a lot of small grey spots, which are sometimes confluent; exterior line consisting of large grey spots, sometimes preceded by an incomplete series of smaller ones. Hindwings with a curved irregular double row of spots, the three pairs nearest the inner margin more or less confluent with a blotch, which, however, is not widened on the inner margin hindmargin with a series of subcontiguous grey lunules, a grey costal spot, a small spot on inner margin, and sometimes traces of one or two intermediate ones.

Expanse of wings: 60 to $62 \mathrm{~mm}$.

Sikkim ; Darjiling.

\section{Abraxas paucinotata sp. nov.}

Basal patch and anal blotch large, and irregularly rounded; the latter on the hindwing also widened along the inner margin; spots and markings pale leaden grey; a large central grey blotch before the end of cell, followed by a smaller one beyond it, and continued more or less irregularly to the inner margin; exterior line of grey spots curved, sometimes geminated and horizontally confluent; preceded on costa by the usual conspicuous grey costal blotch; hindmargin and fringes grey, preceded by a confused series of irregular small grey spots. Hindwings with a submarginal curved series of grey spots, often geminated, preceded by a small grey spot on inner margin and on costa ; hindmargin with detached grey lunules.

Expanse of wings: 52 to $54 \mathrm{~mm}$.

Khasia Hills; Darjiling; Thibet.

\section{Abraxas suffusa sp. nov.}

Closely allied to paucinotata Warr., but slightly smaller; all the markings dark leaden grey, and more extended, the basal and anal patches all much blacker; the discal patch is often largely developed, and the whole of the apical region more or less filled up with dark grey; exterior line formed of oblong grey blotches; hindmargin with a usually prominent dark grey patch about the middle. Hindwings as in paucinotata, but with a large grey bloteh on the costa, which is produced more or less continuously to the grey blotch on the inner margin.

Several specimens from Thibet. It seems to be a parallel form to Butler's miranda from Japan, which also occurs on the Khasia Hills.

\section{Abraxas intermedia sp. nov.}

Distinguished at once by the shape of the anal blotch of the forewings, the edges of which are obliquely sinuous, and which is connected above with a smaller irregular shaped greyish blotch; exterior line represented by a curved series of small grey irregular dots, sometimes almost obsolete; a few grey costal spots, partially confluent in middle, sometimes with a few discal spots below them; the 
usual large costal spot before the exterior line distinct; hindmargin clouded with leaden grey from anal angle to just before apex. Hindwings with an irregular triangular blotch on inner margin, with traces of a curved line of dark spots, but these more often than not obsolete; fringe with dark disconnected blotches.

Expanse of wings: $8,54 \mathrm{~mm}$. ; $\uparrow, 56 \mathrm{~mm}$.

Subathu.

\section{Abraxas disrupta sp. nov.}

Anal patch narrowed and oblique in both wings ; costal markings much reduced; a small discal bloteh connected with a costal blotch above it, and having another obliquely below it; exterior line of small grey spots; as a rule, the whole wing is covered with small detached irregular grey spots; hindmargin dark grey with a grey bloteh about middle. Hindwings with an irregular double row of grey spots, the anal blotch narrow; the central blotches variable; sometimes only a costal and inner marginal blotch; sometimes two or three intermediate, and at others none at all. In three $i f$ from the Khasia Hills the smaller spots are absent, and the anal bloteh is slightly, but only slightly, expanded, on the forewings, while the discal leaden spots are more developed.

Expanse of wings: $\delta, 50$ to $56 \mathrm{~mm}$.; $\uparrow, 58$ to $60 \mathrm{~mm}$.

\section{Abraxas determinata sp. nov.}

Allied to intermedia Warr., but smaller; the anal blotch variable; generally narrow and oblique, now and then broader and more conspicuous, but never large and swollen; basal blotch restricted, usually with a dark curved edge from the costa; costal spots variable; one in centre, generally connected with a discal blotch, which is very irregular in size and shape, and generally has some smaller grey blotches below it; costal exterior spot distinct; exterior line of spots also distinct; hindmargin and fringes narrowly grey; a dark grey blotch in the middle; apex generally pale. Hindwings with narrow anal blotch, and curved row of grey submarginal spots; a grey spot on costa and inner margin; hindmargin with more or less connected dark grey blotches, which in pale specimens are nearly obsolete.

Subathu; Khasia Hills. Those from the latter locality slightly more strongly marked.

Expanse of wings : 48 to $50 \mathrm{~mm}$.

\section{Abraxas symmetrica sp. nov.}

Of the same size and shape as $A$. determinata, but with all the markings much darker and more developed; basal patch and anal patch dark, the latter oblong and oblique; costa well spotted with dark leaden grey; discal blotch large, connected with central costal spot, and in the $\delta$ with a horizontal extension as far as the basal patch, continued beneath as a narrow somewhat broken grey blotch to the inner margin; the end of the discal blotch beyond the cell is protuberant, and contains within it a small white spot; exterior line double towards the costa; apex with several small grey spots; hindmargin narrowly grey, with a broader spot in the middle. Hindwings with the exterior line of spots double, in regular pairs on the veins; an inner grey line, starting vertically from the costa and then bent nearly at right angles towards the inner margin; hindmargin with dark grey blotches.

One of $48 \mathrm{~mm}$., one $₹ 46 \mathrm{~mm}$., from the Khasia Hills. 


\section{Abraxas latifasciata sp. nov.}

This may be only a dark aberr. of suspecta, but it does not seem to occur in China. All the markings are much darker leaden grey; but in particular the exterior band of spots becomes confluent and broad, while the discal spots often form a second dark and irregular band; the band of the hindwings is similarly exaggerated; this darkening is, however, chiefly confined to the $q q$; the $\delta \delta$ are only slightly more marked than in suspecta, but on the other hand they are almost as large as the $q+$.

Several examples of both sexes from Japan.

Expanse of wings : 46 to $48 \mathrm{~mm}$.

\section{Abraxas fulvobasalis sp. nov.}

In this form the darker markings are more or less obsolescent; the basal patch is always margined with black, but within the margin is almost entirely reddish fulvous; the central costal spot is quite small and dark in the $\delta \delta$, sometimes more diffuse and irregularly elongated in the $q f$; the exterior band of spots is distinct, the spots themselves elongated and rarely confluent; hindmargin narrowly and concisely dark, with sometimes a small dark projection in the middle. Hindwings with the exterior band distinct, of single spots; with a large interior subcostal spot, and a smaller one on the inner margin.

Expanse of wings : 36 to $48 \mathrm{~mm}$.

A good series of both sexes from Japan, the Corea, and China.

\section{Abraxas suspecta sp. nov.}

Like miranda Butler, but much smaller, the $\delta \delta$ occurring as small as $38 \mathrm{~mm}$., the $q f$ reaching $50 \mathrm{~mm}$. It is possible that these are a second brood of miranda.

Examples of this form oceur from various parts of both China and Japan.

\section{Abraxas deminuta subsp. nov.}

This appears to be a still smaller and neater form of suspecta. The central costal blotch is much reduced in size, and is proportionally darker and more concise in outline, often assuming a hooked shape, and rarely connecting with the smaller spots below it, except now and then in the $q f$; the exterior band in both wings is dark and well marked. The series from Gensan is smaller than that from Japan, most, if not all, of which examples are from Hakone.

The smallest Gensan $\delta$ expands about $34 \mathrm{~mm}$., and the largest Japan $q$ about $48 \mathrm{~mm}$,

\section{Abraxas degener sp. nov.}

White with pale grey markings, like those of leopardina Koll., of which it may be only a still smaller form.

The smallest $\delta$ is only about $34 \mathrm{~mm}$., the largest about $44 \mathrm{~mm}$. All are from China, and all $\delta \delta$.

\section{Abraxas incolorata sp. nov.}

Wings dull whitish; spots pale grey ; base of forewings yellowish, edged with a curved dark grey line interrupted in the middle; costa near base with some small irregular grey spots, one round one standing by itself below the cell on the submedian 
fold; discal spot large, grey, with another above it on the costa, each followed by a second; these latter two represent the exterior line, which is further indicated by two minute dots on the second and first median nervules, and a larger one on the submedian nervure; submarginal line represented by a regular series of eight grey spots, the upper four close together and directed outwards; the lower four further apart directed inwards, and placed on the three median nervules and submedian nervure respectively; this row is preceded by a small spot near the costa and a larger geminated one on the costa; an irregular series of grey spots immediately before the hindmargin. Hindwings with a regular submarginal row of round grey spots and a single one on the middle of the costa and inner margin, some small grey spots at the anal angle and along the hindmargin. Underside like upper. Head, thorax, and abdomen yellow, with darker spots.

Expanse of wings : $50 \mathrm{~mm}$.

One $\delta$ from Java.

Near urganda Cramer, but apparently distinet.

\section{Abraxas flavisinuata sp. nov.}

Wings white, with dark smoky grey markings; a dull yellow basal patch. extending twice as far along the costa as on inner margin, edged with smoky grey, and followed on the costa by an irregular lot of small grey spots; cell spot circular, with a blackish central nucleus, united with costa by a dull grey blotch, and beneath it obliquely with a curved grey line, which reappears on the inner margin ; exterior line yellow, sinuons, preceded by contiguous roundish dark grey blotches, and followed by contiguous oblong ones, the line and the blotches suddenly ceasing just above the middle of the wing; two large grey blotches on the costa before apex, the inner one with a smaller blotch below it, the two together being the termination of the inner line of blotches, the larger one before the apex representing the outer line; hindmargin irregularly and narrowly dark grey, with a few irregular grey spots before it near the anal angle. Hindwings with small grey discal spot, and curved series of grey spots between it and hindmargin, that on the inner and costal margin geminated; costa, inner, and hindmargins all dotted with grey spots, those on the hindmargin forming a more or less contiguous narrow line; thorax and head dark; patagia yellowish; abdomen absent. Underside of wings like upper.

Expanse of wings: $52 \mathrm{~mm}$.

One from Japan.

This species is, of course, nearly allied to grossulariata L., but is quite distinet from any known form of variation of that species. It comes very close to my species A. metamorpha, from Sikkim.

\section{Abraxas fasciaria Guen. notata subsp. nov.}

Forewings white; markings pale leaden colour; extreme base and three interrupted fasciae leaden coloured; the third of these fasciae is attenuated on the right wing, and represented by a costal spot on the left; a large leaden discal spot; a broad sinuous leaden exterior fascia, narrower towards costa, where it is preceded by a costal and subcostal spot, the latter nearly touching it; an irregular submarginal fascia of leaden spots; fringe leaden coloured. Hindwings the same, but with the markings reduced; only two ill-defined basal fasciae, and the exterior fascia represented by a series of subcontiguous roundish blotches. Face dark; vertex orange; thorax and abdomen yellowish, with black spots. Underside like upper. 
One $q$ from the Nilgiris, among fasciaria, from Mr. Lindsey's collection; smaller than the ordinary $q q$ of that species, and slightly larger than the $\delta \delta$. It may prove to be distinct when more examples are compared.

\section{Abraxas (?) concinna sp. nov.}

Forewings chalk white, with dark grey markings, which are slightly tinged with reddish brown; basal third irregularly filled with greyish markings, giving a generally mottled appearance, especially towards the costa, bounded by a darker curved band consisting of irregular shaped blotches, that on the costa the largest, subquadrate; a smaller one beneath it in the middle roundish; central area pure white, followed by two eurved bands of small round greyish spots, the second of which forms a larger irregular dark blotch in the middle of the wing; apical area and space at the anal angle more or less filled up with dark grey ; between them a white unsuffused blotch in the middle beyond the dark blotch of the second line of spots; subterminal line whitish, distinct, denticulated across the dark upper and lower grey suffusion; fringes dark grey, except the small space at the outside of the whitish patch, which also remains white. Hindwings like forewings, but with the anal angle only suffused with grey; fringe white, narrowly marked with dark grey at the ends of the veins, and with a series of broad contiguous grey lunules at the base. Head, palpi, and antennae dark grey; face narrowly white; thorax grey mottled with whitish; abdomen yellowish, with black dorsal blotches. Underside like upper; pectus and abdomen beneath yellow; legs yellow; the first and second pair much suffused with blackish.

Expanse of wings : $50 \mathrm{~mm}$.

One $\delta$ from Thibet.

The species may be easily recognised by the very neat and symmetrical grey markings; it does not seem closely allied to any other species.

\section{Abraxas membranacea sp. nov.}

Wings very translucent, glossy, thinly scaled; the veins yellowish; the whole wings exceedingly pale greyish ochreous; extreme base and costa of forewings greyish; a faint grey discal spot, and beyond it an indistinct sinuous grey line; fringe slightly darker. Hindwing entirely without markings. Head, face, collar, and thorax yellow; patagia whitish; abdomen pale mouse colour, white beneath.

Expanse of wings: 30 to $38 \mathrm{~mm}$.

A pair from Oinainissa.

The consistency of the wings recalls Nudaria mundana.

\section{Veniliodes gen. nov.}

Resembles Zerenopsis and Diptychis; but the apex of both wings is more pointed; the hindmargin less oblique; the wings themselves broader in proportion; the antennae of the $\delta$ are shortly, but stoutly, pectinated; hind tibiae not thickened; discocellular with the lower arm only slightly oblique.

Type: Veniliodes pantheraria Feld. (Lomaspilis).

\section{Veniliodes inflammata sp. nov.}

Wings deep tawny yellow; markings black; a large spot at the base; an oblique basal fascia formed by two spots, one costal, vertically oblique; the other on the submedian fold laterally elongated; at one-third of the costa an oblique 
small sugar-loaf shaped blotch, pointing to a round spot on the median, vertically beneath which is another on the submedian fold; at one-half and three-fourths two more spots of the same shape, but more elongated, the first followed by two round spots, one on the submedian, the other on the fold; these two are followed immediately by a similar pair close to the anal angle, containing a smaller oval spot between them; the latter is followed at the middle of the hindmargin by four spots placed quadrangularly, the two lowest confluent, the outside upper one smaller than the rest; apex and apical half of hindmargin with the fringe black; lower half of fringe concolorous. Hindwings with apex black, and seven spots, one at the costa, one at the anal angle, three round ones, forming an equilateral triangle in the middle of the hindmargin, and two smaller ones, one discal, the other beyond it; fringes yellow except against the black apical blotch. Underside precisely similar. Head, face, tongue, antennae and thorax black; collar, palpi, and patagia orange fulvous; abdomen yellow with broad black segmental rings above; legs cinereous.

Expanse of wings: $28 \mathrm{~mm}$.

One $\delta$ in the Feld. collection from South Africa; placed among V. pantheraria Feld. That species has the fringes black except for a short space at the anal angle, and ail the markings plumbeous; selinata Feld. has the fringes of both wings wholly dark.

\section{Zerenopsis gen. nov.}

Resembles Diptychis Feld., with the following differences: the discocellular is angulated, especially in the hindwings, where the upper arm is short and vertical, the lower oblique and three times as long. Neuration of hindwings in $\delta$ normal; antennae alike in both sexes, thick, laminated.

Type: $Z$. leopardina Feld.

\section{Xanthabraxas gen. nov.}

Forewings with costa very convex, almost shouldered at base, and again convex before apex, which is bluntly rounded, and not pointed; hindmargin uniformly curved. Hindwings with their hindmargin well rounded. Palpi weak, subrostriform, horizontally porrect; third joint hardly visible, slightly drooping; tongue weak; antennae of $\delta$ thickened and laminated; hind tibiae of $\delta$ not thickened, with two pair of spurs; abdomen long. Neuration : cell two-thirds as long as wings; discocellular hardly angulated in middle; lateral margins of cell towards the end inclined inwards; first median nervule from beyond two-thirds; second at seven-eighths; third from lower angle of cell; lower radial from middle of discocellular; upper from top angle of cell ; common stem of last four subcostals at seven-eighths; first subeostal free. Hindwings: costal closely approximated to subcostal for half the length of cell.

Type: $X$. hemionata Guen. (Abraxas).

\section{Panthera conglomerata sp. nov.}

Wings bright pale straw yellow; markings fuscous purple-viz., a small basal patch; a curved, darker edged fascia with three darker central spots, not quite touching inner margin; an elliptical costal blotch, also dark edged, and containing the large dark discal spot, and a broad irregular marginal band, formed by the 
conglomeration of all the other usual blotches, leaving only a small yellow spot near the hindmargin above the anal angle. Hindwings with a large round discal spot, a costal blotch above it, and a round blotch on inner margin above the anal angle; anal angle itself occupied by a larger roundish spot; marginal fascia, about half as broad as in forewings, with a small yellow spot on the hindmargin below the apex. Underside the same. Head, thorax, and abdomen fuscous grey; anal tuft and sides of pectus beneath yellowish.

Expanse of wings: $46 \mathrm{~mm}$.

One $\delta$ in Feld. collection without locality; another example in the British Museum is from Bogotá. I think this form must be considered to indicate a good species; the ground colour is decidedly paler and less yellow than in any of the other forms, and the markings are in proportion darker and deeper. The outline basewards of the marginal band will no doubt vary in different examples, according to the size and shape of the conglomerated spots.

\section{SubFamily NEPHODIINAE.}

A group of American genera, in the $\delta$ of which, instead of the fovea of the forewings, there exists a short unconnected oblique bar, sometimes very indistinct.

\section{Carpella angustilinea sp. nov.}

Forewings satiny white, with the markings precisely the same as in districta Wlk., but only a third as broad and very concise.

One \& from South America, without exact locality.

\section{Carpella innotata sp. nov.}

Wings pure silky white; the costa of the forewings narrowly black from base to apex. The $q$ has the antennae pectinated, but more shortly than in the $\delta$. I have not seen a $q$ of any of the other three species of Carpella.

Expanse of wings: $52 \mathrm{~mm}$.

One $\delta$, one $q$ from South America.

\section{Carpella (?) nubilata sp. nov.}

Wings dull silky white, with the costa broadly but concisely, the hindmargin diffusedly, smoky grey; an irregularly wavy whitish subterminal line is visible through the grey; two smoky grey brown lines; the first, vertical, at one-third, finer than the second, and incurved shortly at costa and inner margin; the second thicker and darker, straight, from three-fourths of costa to two-thirds of inner margin, where it is twice as near the first line as on the costa; the smoky hue of the costa, just before this line, extends as far as the cell; fringe smoky grey. Hindwings white, with a single central straight smoky grey line and grey fringes. Face and collar dull smoky grey; palpi and antennae black; tongue yellow; thorax and abdomen luteous grey. Underside: forewings with first line absent; the second, the costa, and a large subapical blotch dark smoky fuscous; hindwings with the costa diffusely, the central line, and an additional submarginal curved shade, smoky.

Expanse of wings: $52 \mathrm{~mm}$.

One of from South America. 


\section{Nephodia Hüb.}

Three species are referred by Hübner to this genus in the Zuträge, viz., nubilaria, ii., p. 32 , No. 198, figs. 395 , 396 ; aerinaria, iii., p. 16, No. 226, figs. 451, 452 ; and vaporaria, iii., p. 22 , No. 238 , figs. 475,476 . Of these the first, nubilaria, is also mentioned in the Verz., p. 312, No. 3017, and this will stand as type of the genus. Among the species placed by Guenée in his Nipteria occur some with the $q$ antennae pectinated like the $\delta$, and others with them simple. I am not aware that the $q$ of Huibner's type species nubilaria is known; but the figure of the $\delta$ is so manifestly akin to discoloraria H. S., which has pectinated antennae in the $q$, that I have no hesitation in retaining the name for this group ; in which case Guenée's generic term Nipteria may be reserved for those species which have the antennae of the $q$ simple.

Nephodia styracaria sp. nov. (Morritz MS. in Feld. coll.).

Extremely like incoloraria Guen., and of the same size; but the tint is more luteous, less grey; and the antennae of the $q$ are pectinated.

No doubt, from their great similarity, the two species are often confounded, especially the $\delta \delta$.

\section{Nipteria grisescens sp. nov.}

Wings silky grey, without the luteous tint of vulgaris Warr., from which it also differs by its larger size and in having the lines of the underside more apparent above. Underneath, the line is not marked by black dots on the nervules, but by a broadish dark fascia, and the wing is generally much more thickly mottled and shaded with grey or fuscous.

Expanse of wings : $50 \mathrm{~mm}$.

Three $\delta \delta$ and two $q$ from Brazil.

\section{Nipteria vulgaris sp. nov.}

Like aerinaria Hiib., and about the same size; not so silky in appearance, and with a slight but perceptible elbow in the hindmargin ; more thickly scaled throughout, and not showing the pale space along the inner margin; instead of a curved dark shaded line as in aerinaria, the line is fine, straight, and oblique from the costa near the apex. On the underside it is well marked by black points on the veins, whereas it is not represented at all in aerinaria.

Two $\delta \delta$, four $q q$ from Petropolis, Santos, and Sao Paolo.

\section{Nipteria munda sp. nov.}

Forewings silky grey, paler in the median area; a distinct and comparatively large, blackish cell spot; an oblique dark line slightly waved from the costa before apex, which becomes obsolete on reaching the third median nervule. Hindwings with only the cell spot. Underside more striated, with the line marked distinctly, but more thickly, in both wings.

Expanse of wings: $34 \mathrm{~mm}$.

Two of o from Sao Paolo.

The smallest species of the genus. 
Hyalospila gen. nov.

Forewings elongate; costa straight, evenly curved in the apical third; apex rounded, blunt; hindmargin oblique and slightly eurved; anal angle distinct. Hindwings elongate with hindmargin rounded. Antennae of $\delta$ strongly pectinate; palpi porrect, slender, upeurved ; tongue present ; hind tibiae with four spurs; wings hyaline, very thinly sealed, almost transparent; forewings with the foveal bar very faint. Neuration : forewings, cell two-thirds as long as wing, constricted towards the end; first median at five-eighths, second at seren-eighths, third from lower end of cell ; first and second concave upwards, third concave downwards ; lower radial from centre of discocellular; upper from top end of cell, both concave downwards; last three subcostals on a common stem from the last bend of the subcostal nervure ; first subcostal anastomosing with costal, then with second subcostal, and finally with the third. Hindwings with costal and subcostal approximated for nearly half of cell ; first subcostal and second median nervule from before end of cell.

Type: H. hyalaria H. S.

\section{Hyalospila distans sp. nor.}

Near to H.hyalinaria H. S., but smaller; the second crossband of the forewings nearer the first, starting from the costa at two-thirds, and reaching the inner margin also at two-thirds, less curved outwards and not touching the hindmarginal border above the anal angle; costa of hindwings more broadly blackish.

Expanse of wings: $44 \mathrm{~mm}$.

One $\delta$ from Santos.

\section{Penthophlebia gen. nov.}

Forewings elongate; costa straight for two-thirds, then curved; apex blunt; hindmargin obliquely curved. Hindwings with hindmargin rounded. Antennae of $\delta$ pectinated; palpi short, slender; tongue present; hind tibiae with ? four spurs. Neuration: forewings, cell half the length of wing; first median at two-thirds, second just before end, third from end of cell; lower radial from centre of discocellular, which is straight and nearly vertical; upper radial from the common stem of the last three subcostals, which starts from end of cell; first subcostal nervule anastomosing first with costal, then with second subeostal, and ? again with third. Hindwings with costal shortly approximated to subcostal; two subeostal nervules on a common stem; medians as in forewings. Forewings with the foveal bar well marked.

Type: Penthophlebia radiata Feld. (?Genussa).

Stibaractis gen. nov.

Forewings with costa gradually curved, apex blunt, but squared; hindmargin vertical in the apical half, then curved; anal angle distinct. Hindwings with rounded hindmargin. Antennae ( $f$ ) subserrate, with short bristles; tongue present; palpi short, thin, porrect. Neuration as in Hyalospila, in the main, but the cell not so long; the discocellular eurved and much more oblique; the second median and common stem of last three subcostals rise much nearer the end of cell, especially the latter; all the veins are thicker and stouter, and thickly marked in black.

Type: Stibaractis dioptis Feld. (Genussa). 


\section{Dyschoroneura gen, nov.}

Allied to Perigramma Guen., alike in size, shape of wings, and general structure, and in neuration except in one particular point, which is enough to characterise the genus. The first median vein of the forewings, instead of starting at half the cell and running straight, is suddenly deflexed from the median just beyond the basal fovea so as nearly to touch the submedian fold, above which it runs parallel, to the hindmargin. In the hindwings the position of the first median is quite normal.

Type: Dyschoronewra obsolescens sp. nov.

\section{Dyschoroneura obsolescens sp. nov.}

Forewings dingy white, with the costa, fringe, and veins luteous-fuscous. Hindwings the same. Underside with the costa, hindmargin, and apex broadly fuscous; this fuscous tinge shows through on the upperside as a bluish grey suffusion. Thorax and abdomen dull whitish; face and collar dingy luteous; palpi and antennae and outside of legs fuscous.

Expanse of wings : $48 \mathrm{~mm}$.

One $\delta$ from Santa Rosa.

Myrmecophantes gen. nov.

Wings ample, elongate. Forewings with costa straight except at the extreme base and before apex; apex blunt; hindmargin obliquely rounded. Hindwings with hindmargin rounded. Thorax and abdomen unusually slender; face and eyes large; antennae of $\delta$ well pectinated ; ? no fovea at base of forewings.

Type: M. albifascia Mssn. (Genusa).

Inca gen. nov.

I propose this name provisionally for a genus to contain two species which Mr. Druce calls Nephodia, but in which the figure represents the $\delta$ antennae as simple.

Type: Inca oreades Druce (Nephodia).

Bombycodes Guen. (Phal., ii., p. 219).

In his diagnosis of this genus, Guenée states that the hindwings possess a radial; this is true only of his third species, cypraria, the locality of which was doubtful, but which he was inclined to refer to America, as being the habitat of the other two species. We now know that cypraria is an Indian species, and identical with Walker's previously described Naxa textilis. If Guenée's genus be retained,- - with the correction that the hindwings are without a radial,-its position will be here; and the type will be Cramer's festiva, with which Guenée's rspilaria is identical.

\section{Neuromelia gen. nov.}

Wings ample; costa slightly curved; apex blunt, sometimes much rounded; hindmargin obliquely rounded. Hindwings with rounded hindmargin. Antennae of $\delta$ pectinated, of $q$ simple, slightly thickened; palpi short, not extending 
beyond face. Neuration normal; in the $\delta$ forewings the unconnected oblique bar exists in the spot where the fovea usually stands, as in Genussa Wlk. and other allied genera. Wings white with darker veins and no other markings.

Type: N. selectata Guen. (Scoria).

In several of the species which I have placed in this genus the $q f$ are not at present known, and their position must therefore be considered provisional only.

Neuromelia (?) fumosa sp. nov.

Larger than N. sericea; smoky grey, darker along costa and hindmargin of forewings; veins darker; costa, at the base itself, black; thorax and abdomen concolorous; face yellowish. Underside mealy white; forelegs externally tinged with fuscous. In the forewings the apex is unusually rounded.

Two o o from South America.

The generic position must remain doubtful till the $q$ is known.

Neuromelia (?) obfuscata sp. nov.

As large as festiva Cram., but dull grey; not so smoky as in fumosa Warr.; veins yellowish; costa of forewings black from base to apex; face dark fuscous; apex of forewings produced, blunt; hindmargin oblique. Underside yellowish white; legs, on the outside, black.

One $\delta$ from South America; $q$ not seen.

\section{Neuromelia sericea sp. nov.}

Larger than $N$. impositoria Wlk. ; costa of forewings narrowly black from base to near apex; costa itself straighter than in impositoria; apex rounder; hindmargin less oblique. Underside white; antennae and tarsi black, or black marked.

A pair from South America.

\section{Subamily BISTONINAE.}

Amphidasydae Auct. Eubyjinae Warr. (Pr. Z. S., 1893).

\section{Amraica recursaria.}

Boarmia recursaria Wlk., xxi., p. 374, . Type in S. C. . Central India. Swinh., Cat., No. 3335 .

$"$ ferrolavata

Wlk., xxvi., p. 1536, f. Type in B. M. India.

," solivagaria

Swinh., Cat., No. 3322 . . . . .

, ponderata Feld., Reise Nov., Pl. CXXV., fig. 18.

Type in R. C. . . . . Cochin China.

Amraica fortissima Moore, Lep. Coll. Atk., p. 245, ठ . . Bengal

Amraca $\quad$, Swinh., Cat., No. 3352 .

The type of ponderata Feld. from Cochin China is certainly referable to the Indian species, and not to superans Butler. Besides the difference in the direction of the exterior line as it leaves the costa, the Indian species always shows a large distinct cell spot above, which is only visible beneath in the Japanese species. Col. Swinhoe's identification of Moore's fortissima, of which $\delta \overrightarrow{0}$ only are known, with Walker's earlier species, represented by $q f$ only, is undoubtedly correct. 
Phthonosema gen. nov.

Allied to Amruica Moore, but with the $\delta$ antennae bipectinated plumose: forehead flat; palpi short, porrect; tongue developed; no fovea in forewings of $\delta$; hind tibiae of $\delta$ rather thick with four spurs; ovipositor of $q$ exserted.

Type: Phthonosema tendinosaria Brem. (Amphidasis).

\section{Blepharoctenia gen. nov.}

Allied to Busura Wlk., but separated by the structure of the $\delta$ antennae; in Buzura these are pectinated, the pectinations being oblique in respect of the shaft, tipped with a tuft of cilia, and laterally eiliated ; in Blepharoctenia the pectinations are quite short, perpendicular to the shaft and with much longer tufts of eilia; the pectinations decreasing gradually in size to the apex, whereas in Buzura the apical fourth is simple.

Type: B. bengaliaria Guen. (Amphidasys).

N.B.-B. thibetaria Oberth. = regalis Moore, is an exception to both genera; the $\delta$ antennae being sharply subserrate, and the tufts of cilia rising from the serrations.

\section{Blepharoctenia arenosa sp. nov.}

Forewings pale ochreous dusted with dark atoms; the lines as in contectaria Wlk., but finer and less distinct; the first preceded by a blackish, not ochreous, shade. Hindwings much suffused with darker and more thickly dusted with black atoms; the line only distinct near the anal angle; hindmargin there paler; no cell spot on either wing. Underside with the markings still less distinct, and with only a faint ocelloid cell spot on the hindwings. Head, thorax, and abdomen pale ochreous dusted with darker atoms.

Expanse of wings: $85 \mathrm{~mm}$. + .

One $q$ in Felder collection, recorded from Java. Nearest to my species insularis from Nias Island, but quite distinct.

\section{Blepharoctenia insularis sp. nov.}

Wings pale ochreous, suffused throughout with yellowish and densely mottled with black atoms; basal line indieated only by a dark blotch between the median and submedian veins, followed by a short fine line; no exterior line, but instead an undulating blackish shade from the anal angle nearly parallel to hindmargin and ending opposite the cell in two darker projections, followed by a similar double blackish blotch on the hindmargin; the blackish shade edged with a paler line. Hindwings with a slightly darker ochreous fascia edged with paler, and running right across the wing; indications of a dark grey oblong cell spot. Underside much more thickly strewn with black atoms and striae, with the black shade of the forewings much more strongly marked; both wings with a large blackish cell spot. Head, thorax, and abdomen ochreous dusted with darker atoms.

Expanse of wings: $88 \mathrm{~mm}$. + .

One $q$ from Nias Island.

Although I have not seen a $\delta$, the resemblance of the insect to contectaria Wlkis so great that there is little doubt that it belongs to this genus. 


\section{Buzura pura sp. nov.}

Wings glossy, pale ochreous, with no dark mottling whatever; lines indistinctly yellowish ochreous; basal line fine; central line sinuous, rather thicker ; subterminal forming a broadish fascia with undulating margins; fringes also yellowish ochreous. Underside of wings and abdomen pale ochreous, unmarked. Head, face, and thorax yellow ochreous.

Expanse of wings: $74 \mathrm{~mm}$. + .

Three $q$ f from South Celebes.

\section{Iulotrichia gen. nov.}

Akin to Buzura Moore, but characterised by the extraordinary development of the antennae of the $\delta$. In these each joint bears a pair of very long approximated fascicles of cilia on each side, at right angles to the shaft; these are very strongly ciliated both laterally and vertically, and diminish in length suddenly at base and towards apex, which is quite simple; the hind tibiae are weaker than in Buzura, with four spurs.

Type: Iulotrichia buzurata sp. nov.

\section{Iulotrichia buzurata sp. nov.}

Forewings whitish ochreous, much dusted with fuscous atoms; first and second lines brown, the first wavy, the second denticulated; a dark linear cell mark; subterminal wavy ; fringes concolorous, with a row of dark round dots at base. Hindwings the same, with the two lines nearer together, especially on inner margin. Underside dull whitish ochreous, without markings. Head, thorax, and abdomen concolorous; antennae rufous.

Expanse of wings: $54 \mathrm{~mm}$.

One $\delta$ from Oinainissa (Timor).

The specimen above described is considerably worn, and when fresh was probably much better marked.

Megabiston gen. nov.

Forewings with costa strongly and abruptly shouldered at base, then straight to apex, which is much more prominent than in Biston; hindmargin obliquely curved, and very faintly wavy. Hindwings with the apex produced, and hindmargin only faintly and somewhat irregularly eurved. Head, palpi, pectus, and legs all hairy ; costa of forewing near base fringed with hairs ; antennae of $\delta$ extraordinarily plumose, as in Ereuxa, to which genus this by the shape of the hindwings makes an approach. $\&$ like $\delta$, but with simple antennae.

Type: M. dorriesiaria Christ. (Boarmia) = Biston plumosaria Leech.

\section{Amorphogynia gen. nov.}

Intermediate between A pocheima Hiib., the $f q$ of which are almost entirely apterous, and Biston Leach, where they are as amply winged as the $\delta \delta$.

Type: Amorphogynia necessaria Zell. (Biston). 


\section{Amorphogynia necessaria Zell.}

Zeller, who only knew the $\delta$, at first considered this species only a variety of hirtaria, but in 1849 he made it a distinct species. From a remark of Guenée, it would appear that Lederer also did not believe it to be distinct, until he himself captured a $q$, and then he agreed with Zeller's opinion. This $q$ is figured in the Ann. S. Belg., 1865, Pl. III., figs. 11, 12, and is, I believe, the only $q$ known. It would seem to have been given by Lederer to Zeller, and is now in the British Museum collection. To this specimen, contrary to his usual practice, Zeller had affixed no label indicating the donor; but it is palpably the original from which the figure in the Belgian Annales was drawn, and must be considered the type $q$. Zeller's original of type is labelled Ephesus.

\section{SubFamily ASCOTINAE.}

\section{Selidoseminae Meyr. part. Boarmidae Auctores.}

Elphos albifascia sp. nov.

Resembles procellosa Warr., but, instead of the curved pale fascia of that species, with a broad oblique white fascia stretching from the costa between the discal spot and exterior line to the anal angle, the edges being somewhat irregular. Underside of both wings as in procellosa, but the forewings having the oblique white fascia plainly marked.

Expanse of wings: $\delta$ \% $90 \mathrm{~mm}$.

Two $\delta \delta$ from Gunong Ijau, and one $q$ from the Felder collection, said to be from Assam; also one $q$ from S. Celebes.

Distinguished from procellosa by its oblique white fascia and larger size, but belonging to the same group, in which the hindmargins of both wings are less strongly denticulate.

Elphos megaspilata sp. nov.

Akin to E. pardicelata Wlk., but smaller; all the markings much darker, while the ground colour is whiter. The underside has the spots and black markings larger and ampler; and the underside of the hindwings is less mottled with grey.

Four of from the Khasia Hills.

It may, perhaps, be only a local form of pardicelata Wlk.

\section{Elphos moesta sp. nov.}

Wings wholly dull smoky slate colour, with yellow scales and mottlings interspersed; all the lines blackish edged with paler slate colour. Underside as in procellosa Warr., but with still less white showing on the forewing, along the costa, and in the disc, and there much mottled with smoky grey.

Expanse of wings: $84 \mathrm{~mm}$.

One $\delta$ from Gunong Ijau.

\section{Elphos obliterata sp. nov.}

\%. Wings white, mottled with fuscous and dull yellowish; transverse lines as in the allied species, the first preceded by a clear white space, the second with nearly all the upper two-thirds obliterated, the white ground colour forming a broad fascia 
from costa above the discal mark to the anal angle, where it contains an indefinite fuscous blotch; discal spot ocelloid, oblique, connected with a dark costal spot; apical one-third dark fuscous, mixed with dull yellowish, the subterminal line paler, ill-defined. Hindwings white, mottled with fuscous and yellow, more thickly towards base and hindmargin; the yellowish scales are arranged indefinitely as three curved fasciae; no trace of the central black denticulated line. Head and thorax fuscous. Abdomen grey. Underside white, mottled with fuscous. Forewings with a broad blackish hindmargin, which leaves a whitish space at apex and anal angle only, and a smaller spot below the middle. Hindwings with a narrower submarginal fascia, followed by a series of broad whitish horseshoe shaped blotches between the veins, except opposite the cell.

Almost as large as hymenaria.

Three examples in the Feld. collection without locality, but placed along with others recorded as from Assam. A o from S. Celebes evidently belongs here; this is much darker than the $f$, with a well marked broad pale fascia which does not reach the anal angle. The hindwings are almost wholly smoky fuscous. Felder's $f t$ are probably also from Celebes.

\section{Elphos procellosa sp. nov.}

Forewings smoky purplish grey, with an irregular curved pale yellowish white fascia-formed space between the discal spot and the exterior line, broadest on costa, and not reaching the inner margin; in a few cases the basal portion of the wing is varied somewhat with paler markings. Underside of hindwings wholly smoky grey, with a still darker border, which leaves some dull white lunular blotches along the hindmargin and forewings, with the marginal band similar, but with the basal area less completely smoky, being white with fuscous blotches beneath the pale fascia of the upperside.

Expanse of wings: $78 \mathrm{~mm}$.

Six $\delta \delta$, four from the Felder collection said to be from Assam, one from the Nilgiris, and one from Kandy. Much smaller and more sombre looking than E. hymenaria. The hindmargins of the wings suberenulate only.

\section{Xandrames curvistriga sp. nov.}

Forewings whitish, suffused with pale testaceous and fuscous, and mottled with dark fuscous strigae; basal two-thirds and apical region darker, the intervening space whitish, running from costa quite to hindmargin, where it extends from anal angle to halfway up the margin; basal half of wing pale testaceous mottled with darker streaks, with an ill-defined brownish vertical line; cell spot large, elongated, blackish fuscous, traversed by the central shade, which at its lower end makes a short sharp bend basewards, then runs as a slender streak to inner margin before the anal angle; usual exterior line absent ; subterminal line pale, curved from the costa as far as the white blotch in which it is lost, preceded by a deep fuscous costal blotch, and followed by a paler fuscous one, reappearing below the white blotch as a sinuous line terminating at the anal angle; space immediately preceding it dark fuscous; the white blotch at the anal angle beyond it containing some testaceous marks; fringe preceded by dark lunules between the veins, which are most prominent at the end of the white blotch. Hindwings testaceous fuscous, paler towards the base, and deepening into dark fuscous before a pale subterminal line, which : starting from the costa before the 
apex runs slightly sinuous to the hindmargin opposite the cell, then irregularly straight to the anal angle; cell spot dark brownish; faint indications of a central line shown by dark streaks on the veins. Head, thorax, and abdomen testaceous mottled with darker. Underside the same, but duller.

Expanse of wings : $52 \mathrm{~mm}$.

One $q$ from the Khasia Hills.

Much the smallest of the genus, and distinguished at once by the pale marginal line of the hindwings.

\section{Mesastrape gen. nov.}

Like Erebomorpha Wlk. in all respects, but the $q$ has antennae very well pectinated, though not quite so strongly as the $\delta$. The $q$ of fulgurita has them quite simple. The wings of Mesastrape are also shorter and broader by comparison than those of Erebomorpha.

Type: M. consors Butler (Erebomorpha).

Fulguraria Wlk. is, I have no doubt, also a Mesastrape; a closely allied species to it, from Thibet, at present undescribed, has pectinated antennae in the $q$; the of fulguraria is, I believe, unknown.

Duliophyle gen. nov.

Nearly allied to Xandrames Moore, but with the forewings broader, and more rounded at the apex, and especially distinguished by the $f$ having simple antennae instead of pectinated.

Type: Duliophyle agitata Butler (Boarmia).

Sinameda gen. nov.

Distinguished from Medasina Moore by the double toothed prominence in the middle of the hindmargin of the hindwings, and also by the much smaller size and more distinct markings.

Type: Sinameda basistrigaria Moore (Hemerophila).

Racotis boarmiaria Guen. obliterata subsp. nov.

Guenée, in his description of boarmiaria, says that the dark border of the wings on the underside does not at all points touch the hindmargin. If the examples from $\mathrm{S}$. India and Ceylon be taken as answering this description, the two forms from N. India must be separated as subspecies. In that which I call obliterata, the dark fascia is more or less broken up by the paler ground colour. This is more especially the case in examples from the Khasia Hills, though in one instance from Bhotan the dark fascia is all but entirely obliterated.

Racotis boarmiaria Guen. plenifasciata subsp. nov.

In the majority of examples from Bhotan and Darjiling the dark border of the underside of the wings is very broad, deep black, and contiguous to the hindmargin throughout; a single specimen also from the Khasia Hills agrees entirely with these broad banded forms; while in a few cases from Darjiling, though the band is equally broad and black, it has a tendency to become paler towards the hindmargin of the hindwings in the neighbourhood of the anal angle. 


\section{Racotis sinuosa sp. nov.}

Like boarmiaria Guen., but larger. The diseal spots in both wings ocelloid and larger, more distinct. Underside with the ground colour very much suffused with dingy cinereous; the marginal black border broad, touching the hindmargin, and leaving a large whitish apical bloteh on the forewings, and a small pale blotch below the apex of hindwings. In the forewings the inner edge of this fascia is not straight, but irregularly sinuous.

One $\delta$ and one $q$ from North India.

\section{Darisa fasciata sp. nov.}

Forewings pale dull ochreous, thickly dusted with fuscous; lines dark brown : first near base, forming a small subcostal angle, and running obliquely inwards, preceded by a fuscous olive shading; discal spot round, nebulous; second line runs at first outwards, forming a rounded angle opposite the cell, then obliquely inwards to the submedian fold beneath the discal spot, where it curves again outwards; this line is followed by a broad fuscous olive fascia, which is connected with the hindmargin opposite the cell and towards anal angle, and is bounded by the indistinct subterminal line. Hindwings the same, but with no basal line, and the discal spot smaller. Underside like upper, but a little duller.

Expanse of wings : $52 \mathrm{~mm}$.

One $q$ from Sikkim, in Felder collection.

\section{Darisa interlata sp. nov.}

Forewings whitish ochreous, dusted with fuscous strigae; lines dark fuscous; first near base, at one-fourth, forming two sinuses outwards, preceded by a thicker fuscous shade, which reaches neither margin; an indistinct vertical central fuscous shade, which is curved shortly outwards round the dark lunular cell spot; exterior line irregularly dentate and sinuous; runs vertically or slightly inwards from costa, then outwards for a similar distance, then vertically again till near the inner margin, where it curves inwards to some distance before anal angle; marginal area suffused with fuscous olive; a dark brown costal subapical spot, and a dark brown cloud below it; fringe with a dark base line, which swells out into spots at the veins; subterminal line hardly indicated. Hindwings the same, but without first line and median shade; the exterior line evenly curved and strongly dentate. Underside paler ochreous, dusted with fuscous. Forewings with a broad dull fuscous marginal band, which contains three paler spaces - one at apex, the second just below the middle, the third before the anal angle. Hindwings with the band confined to the costal half of the wing, and not reaching the hindmargin.

Expanse of wings : $65 \mathrm{~mm}$.

One $q$ from Sikkim, from the Felder collection.

Paradarisa gen. nov.

Distinguished from Darisa Moore, to which it is certainly allied, by the $\delta$ antennae, which, instead of being pectinated, are only shortly ciliated, as in Ectropis Hüb.

Type: Paradarisa comparataria Wlk. (Tephrosia). 
Alcis angulifera Butler ab. albifera aberr. nov.

Six $\delta \delta$ from Shikotan and one $\delta$ from Nemoro have the central band between the discal spot and the subcostal sinus of the exterior line quite white, unclouded by the grey suffusion; and the central shade, instead of curving round the discocellular spot, passes through it, or only just outside. A $\&$ from Japan, without more precise locality, has the whole of the central band whitish, while in one wing the central shade passes inside the discocellular marking; this is probably the $q$ form answering to the above $\delta \delta$. Even in the type form, the $q f$ (which appear to be far rarer than the $\delta \delta$ ) have the central field much paler than the $\delta \delta$.

Cleora Curtis.

The application of the generic term Cleor $a$ to the lichen-feeding species of Boarmia Tr. was an error of Guenée's. Curtis, in introducing the genus (Brit. Ent., Pl. LXXXVIII.) gave only one species, cinctaria, which must remain the type.

Cleorodes gen. nov.

\section{Cleorodes lichenaria.}

Meyrick has separated this species from those usually allied with it, but made it a Cleora. This is completely wrong, as the type of Cleora Curtis was cinctaria.

I propose the above name for lichenaria.

\section{Ectropis grisescens sp. nov.}

Distinguished from excellens Butler by the smaller size, the entire absence of the dark blotch in the middle of the exterior line, as well as by the line itself being much less sinuate and dentated, in which character the other lines agree. Underside without any markings, but a dark line along the centre of each wing.

Expanse of wing : $\uparrow, 46$ to $52 \mathrm{~mm}$.

Four $q$ o -three from Ningpoo, and one from Hakodate.

The example from Hakodate, which may be called aberr. obliqua, shows this simple formation of the cross lines much more plainly than the others.

Phthonandria gen, nov.

Agreeing in most respects with Hemerophila Stph., but distinguished by the $f$ antennae, which are pectinated, though less strongly than in the $\delta$.

Type: Phthonandria atrilineata Butler (Hemerophila).

Ephemerophila gen, nov.

Near akin to Hemerophila, but with narrower, more elongate wings. Both wings elbowed at the end of the third median nervule, and with the hindmargin deeply dentate. Hindwings with two larger teeth at the end of the first subcostal and third median nervules.

Type: Eph. humeraria Moore (Hemerophila).

\section{Hemerophila subpilosa sp. nov.}

8. Red brown, dusted and suffused with darker and blackish ; lines and markings exactly as in canidorsata Wlk., but a smaller and weaker insect. May be distinguished by the underside of the wings, which from base to outer line are nearly straw colour, hardly dusted with darker, and by the hairy under surface of the hindwings.

Eight $\delta \delta$ from the Khasia Hills. 


\section{Gasterocome gen. nov.}

Forewings elongate, triangular; costa straight till shortly before apex, which is bluntly rounded; hindmargin oblique; anal angle well marked. Hindwings ample, with rounded and slightly waved hindmargin. Forehead prominent below ; palpi porrect, shortly rostriform; tongue present; antennae of $\delta$ very densely but finely ciliated; hind tibiae thickened, with two pairs of short spurs; abdomen of $\delta$ beneath with a thick tuft of hairs in the middle; forewings of $\delta$ without fovea. Neuration: forewings, cell not half as long as wing; discocellular curved, hardly inangulated; first submedian just beyond one-half; second and third from lower end of cell; radials normal ; first subcostal free, from seveneighths; second (?) missing; the other three on common stem from just before upper angle of cell. Hindwings with costal and subcostal very shortly approximated ; two subcostals, and two last medians from same point.

Type: Gasterocome pannosaria Moore (Cleora).

The scaling in this genus is sparse, so that the wings, especially towards the base, appear semitransparent.

\section{Paralcis gen. nov.}

Allied to Gasterocome Warr., but distinguished by the $\delta$ having a very strong raised fovea on the forewing; antennae of $\delta$ armed with pairs of fine curved cilia, much as in Myrioblephara Warr.; palpi hairy, porrect, last joint hidden; abdomen of $\delta$ with no tuft of hairs on the underside, but with the anal tuft well developed. Scaling and neuration as in Gasterocome.

Type: Paralcis conspicuata Moore (Menophra).

Ascotis margarita sp. nov.

Wings white. Forewings with costa and apex speckled with fuscous; basal line much as in selenaria Hüb., double, and obliquely curved inwards; an indistinct central shade; discal spot narrow, sinuous, white, with dark margins; exterior line sinuous, black, but not denticulated, as in selenaria; subterminal line whitish, parallel with hindmargin, with a dark fuscous shade on either side; some small black spots along the base of the white fringes; a small oblong black dash at the hindmargin above the upper radial. Hindwings with a nearly straight dark central line before the indistinct white dark edged cell spot; a black hardly denticulated outer line, followed by a dark grey parallel shade; subterminal line as in the forewings. Underside white, the lines showing indistinctly through; cell spots blackish. Apex of forewings with a black blotch from costa to hindmargin, leaving the apex itself white. Head, thorax, and abdomen whitish, speckled with grey; the abdomen with the segmental divisions grey; tarsi annulated with grey.

Expanse of wings: $50 \mathrm{~mm}$.

One $\delta$ from West Java.

Ascotis sordida sp. nov.

Wings sordid grey, tinged with luteons; finely speckled throughout with blackish atoms, which here and there are denser; costa streaked with fuscous; discal spot dark with paler centre; a row of dark spots along base of fringes, which are concolorous; no trace of any transverse lines. Hindwings with a large 
dark discal spot, preceded by a thick diffuse black shade, and followed by an indistinct slightly denticulate outer line; base of fringes with dark spots as in forewings. Underside with all the diseal spots large and dark and a narrow dark subapical shade, which is also visible on the upperside. Head, thorax, and abdomen concolorous with wings, but more mottled with fuscous.

Expanse of wings : $40 \mathrm{~mm}$.

One $\delta$ from Gensan, Corea. It is just possible this may be a diminutive ill-marked specimen of selenaria. I have, however, seen no intermediate forms.

\section{Chogada fuliginosa sp. nov.}

Forewings dark smoky grey; basal and exterior line blackish, the former curved outwardly, dentate sinuous, enclosing a somewhat darker basal space; the latter dentate, oblique, and forming an angulated sinus beyond the cell; cell spot large, sooty black, placed on a very fine dark central shade; a blackish subterminal shade, edged exteriorly by a paler, regularly dentate, subterminal line; a series of blackish, paler edged lunules before the dark grey fringes. Hindwings the same, but without any basal line. Head, antennae, thorax, and abdomen all very dark smoky grey. Underside dull dark einereous, with the cell spots very distinct, the exterior line indistinct. The $q$ is slightly paler throughout.

Expanse of wings: $32 \mathrm{~mm}$.

Four examples from Engano.

Iridopsis gen. nov.

Differs from the East Indian and Malayan genus Chogada in having longer and narrower forewings, more smoothly and thinly scaled, with the wing membrane showing decidedly iridescent. The antennae of the $\delta$ are differently pectinated, the pectinations being shorter, more regular, and straight, not curving or twisted.

Type: syrniaria Guen.

\section{SubFamly FIDONIINAE.}

\section{(Fidonidae Auct.)}

Metarranthis gen. nov.

Wings broad; forewings arched at base, then straight, or even slightly incurved in middle, to apex; apex rectangular; hindmargin strongly bowed; anal angle distinct. Hindwings broad, with full hindmargin, which is rather indented below apex. Antennae of $\delta$ strongly pectinated to apex; of $q$ acutely serrate; palpi stout, porrect, or inclined upwards; terminal joint short, blunt; tongue present; scaling dense. Neuration: forewings, cell broad, rather more than half as long as the wing; first median nervule at three-fourths, second at seven-eighths, third from lower end of cell; radials from centre of discocellular, and top end of cell respectively; first and second subcostals free; last three on a common stem rising some little way before end of cell. Hindwings without radial; costal approximated to subcostal for about half the cell; first subcostal just before end of cell; medians as in forewings.

Type: M. obfirmaria Hüb. (Epirranthis). Now that pulverata, the type of Epirranthis, is transferred to the Orthostixinae, a new genus is necessary for obfirmaria Hüb. 


\section{Megaspilates gen. nov.}

Forewings ample; costa faintly convex at base and apex; apex prominent, blunt; hindmargin curved, more obliquely in the lower half; anal angle well marked. Hindwings broad, both angles rounded; hindmargin curved. Palpi porrect, slender, long, extending half their length beyond face; tongue weak; antennae of $\delta$ strongly pectinated, the pectinations ciliated finely; of $q$ shortly and evenly pectinated; abdomen stouter and stronger than in Aspilates. Neuration normal. Scaling fine and close, somewhat glossy.

Type: Megaspilates mundataria Cram.

\section{Biclavigera gen. nov.}

Near to Orgyiodes Feld., but without the hairy pectus and thorax; face large, rounded, and protuberant; palpi distinct, short, stout, third joint invisible; hind tibiae with only one pair of spurs; fore and hind tarsi (? middle) ending in a double claw.

\section{Type: B. praecanaria H. S. (Scodiona).}

Orgyiodes Feld. (Reise Nov., ii., p. 3).

Forewings elongate; costa convex near base, and before apex, slightly incurved between; apex blunt, round; hindmargin well rounded; anal angle fairly distinct. Hindwings broad, with well rounded hindmargin, and square anal angle. Antennae of $\delta$ plumose; pectus, face, and thorax very hairy, the short palpi quite hidden; hind tibiae of $\delta$ with two spurs. Neuration: cell three-fifths as long as wings; first median at three-fourths, second just before the end, third from the end of cell; radials as usual; common stem of last four (? three) subcostals some little distance before end; first subcostal free. Hindwings with costal closely approximated to subcostal for half the length of cell ; first subcostal leaving just before end of cell; medians as in forewings; markings much more oblique than in the allied genera.

Type: Orgyiodes caparia Wlk. (Fidonia?).

\section{Aspilates hesperis sp. nov.}

Forewings deep sandy yellow; costa pale ochreous dotted with fuscous; fringe concolorous; a slightly darker yellowish brown oblique line from almost below the apex to the inner margin, near which it becomes indistinct. Hindwings yellowish white, without any markings. Palpi, face, and thorax concolorous with forewings; abdomen with hindwings. Underside of both wings rather bright yellow, paler towards the inner margin; costa of forewings mottled with brown; the line and discal spot distinct, brown. On the hindwings there is a large brown discal spot, and a brown line from the apex reaching half across the wing to the anal angle; the discal spots show faintly through on the upper surface.

Expanse of wings: $34 \mathrm{~mm}$.

Several $\delta \delta$ from the Canaries.

Nearthria gen. nov.

Wings shaped, coloured, and marked very much like Aspilates, but differing in the palpi and $\delta$ antennae. The palpi are short, and porrect, scarcely reaching the front of face; the antennae of the $\delta$ are beset with shorter, curled pectinations, which interlock at their apices.

Type: Nearthria lacticinia Butler (Aspilates). 


\section{Lissoplaga gen. nov.}

Forewings elongate; costa faintly convex near base, and before apex, straight, or slightly incurved, between; apex blunt, rounded; hindmargin rounded; anal angle distinct. Hindwings as long as forewings, the inner angle produced, and much rounded; hindmargin slightly curved. Antennae of $\delta$ minutely pubescent; of $q$ simple; palpi porrect, reaching beyond face; lower part of face with a projection of scales; tongue present; hind tibiae with two pairs of spurs. Cell half as long as wing; first median from three-fourths, second close before end of cell, third from end; radials as usual; last four subcostals on a common stem from before angle of cell. Hindwings with discocellular angulated; costal approximated to subcostal from near base to half the cell ; subcostals on a short footstalk; medians as in forewings. Forewings of $\delta$ with a not very distinct fovea near base; scaling smooth and thin.

Type: Lissoplaga edmondsii Butler (Fidonia).

\section{Psilaspilates gen. nov.}

Near Aspilates, but distinguished at once by the antennae of the $\delta$, which are not pectinated but thick and laminated; the palpi are much broader and shorter, with the last joint drooping; hind tibiae with four spurs.

Type: Psilaspilates butyrosa Butler (Lozogramma).

\section{SubFamly SEMIOTHISINAE.}

\section{Macaridae Auct.}

\section{Dissomorphia gen. nov.}

Forewings triangular; costa nearly straight, convex shortly before apex, which is very bluntly rounded; hindmargin in $\delta$ scarcely perceptibly excavated below apex, and with a very faint elbow above middle; in $q$ with a decided excavation, and a strong tooth above middle. Hindwings with a small tooth in middle of hindmargin in $\delta$, the margin above it hardly wavy, and straight below it; in $q$ with a strong tooth, and the margin visibly crenulated. Palpi long, rostriform, porrect; forehead tufted at base ; tongue present; antennae of $\delta$ thick, armed with curved fascicles of cilia ; of $q$ very minutely serrated. Neuration normal.

Type: Dissomorphia australiaria Guen.

A development of Semiothisa, and confined to Australia and Tasmania.

\section{0xymacaria gen. nov.}

Forewings ample; the costa strongly arched at base and convex before apex ; apex produced, acute, subfalcate; hindmargin incurved below apex, then slightly bulging, and again curving to the anal angle. Hindwings broad, with a distinct tooth in middle of hindmargin; the hindmargin curved above it, and straight below it. Forehead slightly prominent; palpi thick, porrect; tongue present; antennae of $\delta$ shortly and regularly pectinated; of $q$ finely subserrate. Neuration normal.

Type: Oxymacaria palliata Hmpsn. (Azata).

Distinguished from the allied genera by the antennae, and the shape of the forewings. 


\section{Gonodela albipuncta.}

Wings grey brown, faintly purplish tinged, with numerous dark fuscous transverse striae; lines dark brown; first near base, angulated near costa; second in midwing, straight and nearly vertical ; third oblique outwards from costa, forming a blunt angulation, then incurved to inner margin before anal angle, where it is indistinctly geminated; beyond the angle is a long oval white spot; fringes chequered with dark fuscous, preceded by a rather thick black basal line. Hindwings the same, without the basal line, and the outer line straight and geminated throughout. Thorax and abdomen concolorous with wings; head, face, and collar fulvous. Underside bright yellow, with the marginal area darker, mottled with dark fuscous; the apical white spot repeated.

Expanse of wings: $30 \mathrm{~mm}$.

One of from Gunong Ijau.

\section{Subfamly CATOPYRRHINAE.}

\section{Petrodava Wlk.}

Closely allied to Hyperythra Guen., but the $\delta$ is entirely without the varions sexual characters which distinguish that genus; in the hindwings the cell is half as long as the wing, while in Hyperythra it is only two-fifths.

Type: Petrodava albosignata Wlk., xxvi., p. 1656.

This type of Walker's, from an unknown locality, has hitherto remained unique; a $\delta$ and two $q$ f from Bathurst, in the Rothschild collection, are plainly identical; the $f$ is paler and more yellowish. To this genus will belong also Butler's African leucicolor, and Swinhoe's Indian species khasiana and phoenix.

Tycoonia gen. nov.

This is intermediate between Hyperythra Guen. and Syrrhodia Hüb., on the one hand, and Petrodava Wlk. on the other. The $\delta$ has a thickening on the submedian fold near the base, elothed with smooth appressed scales on the underside, and marked by a double fold of somewhat raised scales above. In all other respects it agrees with Petrodava.

Type: Tycoonia obliqua sp. nov.

\section{Tycoonia obliqua sp. nov.}

Resembles the Indian species Petrodava khasiana Swinh. and phoenix Swinh.; but may be distinguished at once by the course of the central line, which does not run parallel to the exterior line, but is nearer to it on the costa than on the inner margin.

Two $\delta$ ठ

Caenarthria gen. nov.

Like Petrodava Wlk., but the antennae of the $q$ are very strongly pectinated.

Type: C. haturata Wlk. (Hyperythra?).

\section{Bithiodes gen. nov.}

Intermediate between Probithia Warr. (=Bithia Wlk.) and Luxiaria Wlk. The antennae of the $\delta$ are simple as in Luxiaria, but the hindmargin is not crenulated; the angle of the hindwings is at the end of the second subcostal vein instead of the third median.

Type: Bithiodes inexactata Wlk. (Acidalia). 


\section{Probithia gen. nov.}

This genus differs from Luxiaria Wlk., both in outline of wings and in neuration. In Probithia the hindwings are decidedly angulated, the hindmargin on either side of the angulation being fairly straight; the neuration in the $\delta$ is quite normal, the nerves all running straight. In Luxiaria, on the other hand, the hindwings have the hindmargin more or less strongly crenulated, never angulated; the neuration of the hindwings in the $\delta \delta$ is distorted; the cell is short and broad; the costal and subcostal are upcurved near base, and bent downwards beyond the cell; further, the $\delta$ antennae are simple, while in Probithia they are long and strongly serrated.

Type: Probithia exclusa Wlk. (Bithia).

Walker's name Bithia (xxxv., p. 1599) is preoccupied; ef. Moore, Ceyl., iii., p. 457 .

\section{Luxiaria fulvifascia sp. nov.}

Forewings ochreous, suffused, and dusted with dull fulvous, without any grey or cinereous admixture, as in fasciosa Moore. The forewings narrower, with blunter apex, and less incurved hindmargin; traces of a fulvous oblique basal and central line; the whole basal area and costal region is much dusted with fulvous; exterior line more distinct, starting from a triangular costal fulvous spot; marginal space, except at apex, fulvous, the apex and central fascia remaining paler. Hindwings with an indistinct central, and three distinct submarginal and marginal fulvous bands. Face, antennae, and thorax fulvous. Underside yellowish fulvous, with the basal and marginal areas dark fulvous; the lines and fasciae dark fulvous and more distinct. Forewings with a clear median line and discal spot.

Expanse of wings : $36 \mathrm{~mm}$.

One $\delta$ from Sumatra, from the Felder collection.

Distinguished from fasciosa Moore by the narrower wings, absence of grey coloration, and rounded hindmargin of hindwing, which shows no trace of a tooth in the middle.

\section{SubFamily ENNOMHNAE.}

\section{Krananda diversa sp. nov.}

Smaller than K. semihyalina Moore, with less irregular hindmargins, the subapical projection of the hindwings being, in particular, greatly reduced. Forewings with the basal area filled up with brown, like the marginal; costal half of the inner edge of the marginal border much more oblique, nearly parallel to the direction of the hindmargin. Hindwings with a broad irregularly outlined central band fuscous; marginal border with a large projection in the middle running out into the hyaline space, whereas in semihyalina it is the hyaline space which there protrudes into the dark border. The line of white submarginal spots is much less distinct in both wings.

Expanse of wings : $50 \mathrm{~mm}$.

One $\delta$ from the Felder collection, unnamed, from Sikkim. 


\section{Trigonoptila gen. nov}

Forewings much elongated, the costa very much longer than the inner margin; costa straight from base to just before apex, where it becomes shortly and suddenly convex; apex blunt; hindmargin straight, very oblique; anal angle well marked. Hindwings broader than forewings, kite shaped; the costa sinuous, slightly concave in the middle; hindmargin excised between the costal and first subcostal, at the end of which is a blunt tooth; thence to anal angle almost straight. Abdomen of $\delta$ long; antennae of $\delta$ with short ciliations, decreasing towards the tip; forehead rounded, rather prominent, with a short projecting rostrum of scales on its lower edge; palpi short, porrect, hairy beneath, the last joint short; tongue present; forewings with a small fovea; hind tibiae thick, with four short spurs. Neuration normal.

Type: Trigonoptila latimarginaria Leech (Krananda).

\section{Zanclopera gen. nov.}

Forewings elongate, slender; costa straight for four-fifths, then convex to apex, which is prominent, but blunt; hindmargin oblique, sinuous, being gently concave below apex, and again more slightly above the anal angle, which is well marked. Hindwings with costa straight; a very prominent tooth between the two subcostals, the hindmargin above it being slightly concave to the costa, and below it perfectly straight to the anal angle. Abdomen long, slender ( $\delta$ ); forehead flat, retreating below ; palpi exceedingly short, not reaching front of face ; tongue present ; antennae of $\delta$ very finely but thickly ciliated, the eiliations rather long; hind tibiae of $\delta$ thickened, with four short spurs; forewings with small fovea. Neuration normal.

Type: Zanclopera falcata sp. nov.

The genus is akin to Trigonoptila Warr. and Krananda Moore.

\section{Zanclopera falcata sp. nov.}

Forewings pale ochreous, flushed with deeper ochreous, or pale tawny, and sparsely dusted with blackish atoms; costa paler, dotted and spotted with blackish; subcostal area deeper ochreous; no visible inner lines; exterior line, fulvous at the costa, curves in above the anal angle, and forms a black oblong spot on the inner margin, with two black dots above it on the second and third median nervules; space immediately beyond this line warmer ochreous, becoming paler again before the fringes, and shining whitish towards the apex; fringes warm ochreous, with their tips brown. Hindwings with the line faintly reproduced, but straight, with some small dark dots towards the inner margin, and the ground colour deeper beyond it. Thorax and abdomen ochreous; face reddish. Underside the same, but with the mottlings and the line stronger and darker, brownish black.

Expanse of wings: $36 \mathrm{~mm}$.

One $\delta$ from Khasia Hills.

Geolyces nom. nov.

\section{Geolyces attesaria Wlk.}

Lyces had been already used by Walker himself (ef. Cat., ii., p. 366) for a distinct group of South American insects. Its employment again for the Congo attesaria (Wlk., xx., p. 249) is, therefore, impossible. 


\section{Metoxydia delineata sp. nov.}

Forewings pale yellowish ochreous, with darker ochreous clouds, and dusted with brownish atoms; all the lines brown ; first line near base forms two strong angulations outwards, and is closely followed by a second line, the costal arm of which is thick, the lower part thinner, incurved, and touching the lower angulation of the first line; median vein and base of the three submedians brown; exterior line, oblique below the costa, forms a short angle towards hindmargin, nearly meeting an oblique brown streak from the apex; then is incurved to just beyond the middle of the inner margin, where it is followed by a small brown blotch; subterminal very indistinct, whitish and wavy; two small round brown spots on hindmargin, beneath apical streak; fringe brown; discal spot distinct, blackish. Hindwings with only the discal spot distinct, and beyond it an obscure fine wavy line; three brown spots below apex; fringe brown. Face, thorax, and abdomen concolorous with wings; palpi and antennae brown.

Expanse of wings : $46 \mathrm{~mm}$.

One $\delta$ from Gunong Ijau, distinguished from the Indian species by the quite simple apex of the hindwings.

\section{Homoeoctenia gen. nov.}

Forewings with costa straight for three-fourths, then gradually convex; apex blunt, hardly produced; hindmargin oblique, faintly concave below apex. Hindwings ample, with hindmargin entire, well rounded. Antennae (ठ) well pectinated; palpi thick, short, porrect; first joint hairy beneath, second globose, third quite small; tongue present. Neuration normal.

Type: Homoeoctenia subflavata Feld. (Xandrames?).

This genus resembles Panisala Moore in general, but differs in the outline of the wings.

\section{Calladelphia gen. nov.}

Akin to Dalima Moore. Forewings with apex much more acute; hindmargin more incurved. Hindwings with the subapical angle much more prominent; antennae of $\delta$ strongly pectinated; the pectinations themselves finely ciliated laterally and at apex. Neuration as in Dalima.

Type: C. patnaria Feld. (Dalima).

Dissoplaga gen. nov.

Forewings with costa rather strongly arched at base, then straight or even slightly concave before apex, which is produced as a bluntly rounded projection; hindmargin faintly indented below apex, then strongly bowed, and slightly coneave again before anal angle, which is well expressed. Hindwings with well rounded hindmargin. Antennae of $\delta$ simple, slightly thicker towards base; palpi short, porrect third joint hardly visible; tongue present; hind tibiae of $\delta$ not thickened, with two pairs of spurs. Neuration normal.

Type: Dissoplaga sanguifua Moore (Cimicodes).

The genus superficially reminds one of Omiza Wlk., but is distinguished by the simple antennae in both sexes. 


\section{Dissoplaga sanguiflua Moore.}

(a) Purpurascens aberr. nov., $\delta$. Both wings almost wholly suffused with deep dull purple, tinged in places faintly with olive, the oblique line remaining olive, and the space immediately before it paler purple.

(b) Olivescens aberr. nov., $\delta$. The red tints wholly absent from both wings, the colour being pale yellowish ochreous, tinged throughout with olive. The underside of this form is much paler than in the type form, while in purpurascens it is much deeper.

Of both aberrations, as of the type form, I have only seen $\delta \delta$. Moore's type is recorded as a + .

\section{Nothomiza gen. nov.}

Forewings with costa arched at base, slightly concave in middle; apex blunt, hardly produced; hindmargin curved, more obliquely in its lower half; anal angle rounded. Hindwings with well rounded hindmargin. Palpi short, porrect, terminal joint not discernible; tongue present; antennae minutely subserrate, in $q$ with a short bristle to each serrature; in $\delta$ with ciliated fascicles of cilia. Neuration : in the forewing, the first subcostal nervule is free, the remaining four on a common stem rising before the upper end of the cell, the second and fifth rising nearly together, the third and fourth separating some distance beyond.

Type: Nothomiza costalis Moore (Cimicodes).

An eastern genus, comprising three or four species, all reddish with yellow costal markings, and the ordinary lines indistinct. In the type species costalis Moore, the apex of the forewing in the $q$ is slightly more produced, and the hindmargin below it more indented than in formosa Butler.

\section{Mimochroa gen nov.}

Forewings triangular; costa straight, curved slightly at base only ; apex slightly produced, rectangular; hindmargin with a decided elbow at the end of the third median nervule, vertical above, oblique below it; sometimes slightly wavy; anal angle well marked. Hindwings with hindmargin wavy, and a small angulation at the end of the third median. Palpi porrect, second joint hairy; third small, pointed; tongue present; antennae of $\delta$ well pectinated to near the apex; of $q$ simple; hind tibiae of $\delta$ with four spurs. Neuration normal; scaling close and dense. Upperside dull coloured; underside yellowish.

Type: M. basipuncta Moore (Endropia).

\section{Mimochroa viridescens sp. nov.}

Forewings grey, sometimes whitish grey, dusted with darker transverse striae, and suffused with various shades of olive; the lines dark olive; the first at onethird, angulated below costa, then running vertically or slightly oblique inwards, to the inner margin; second line from near before apex, forming a blunt elbow below costa, then curving inwards slightly concave to the middle of the inner margin; space from base to second line generally filled up with dark olive green, but this is variable; sometimes the inner margin is much paler; sometimes the outer half of the fascia is alone darker, and the rest tinged with reddish; marginal space grey or whitish grey, with apex narrowly, and two diffuse patches above anal angle, darker olive; sometimes with traces of dark spots between the veins; fringes 
dark olive. Hindwings with a central dark olive fascia, the inner edge of which is straight and the outer angulated in the middle, and joining the inner edge at costa and inner margin; marginal space as in forewings, but with the dark spots more distinct, and with one in the middle always dark and visible. Face, palpi, and front of thorax yellowish olive; thorax darker olive; abdomen paler. Underside delicate yellowish olive, mottled with dark grey; the second line distinct, reddish purple, edged diffusely with whitish; a whitish suffusion at the anal angle of forewings.

Of the same size and markings as gynopteridia Butler, but at once distinguished by the colour of the upper and under sides.

Four $\delta \delta$ from the Khasia Hills.

\section{Mimomiza gen nov.}

Forewings triangular; costa straight; apex not produced, slightly more acute in $q$ than in $\delta$; hindmargin obliquely eurved; in $q$ with a slight elbow in middle, and the anal angle more developed than in $\delta$. Hindwings broad, with rounded hindmargin, which in $q$ has a similar slight elbow to that in the forewings. Palpi shortly rostriform, terminal joint longer in $\delta$ than $q$; tongue present; forehead slightly produced beneath; antennae in $q$ simple; in $\delta$ pectinated, with apical quarter simple; hind tibiae of $\delta$ not thickened, with four spurs. Neuration normal,

Type: Mimomiza cruentaria Moore (Cimicodes).

An East Indian genus, distinguished by the triangular forewings with quite straight costa ; sharp and prominent apex, marked with an oval, white edged, costal spot; and bright yellow colour.

\section{Hygrochroa punctifera sp. nov.}

Wings yellowish ochreous, flushed with deeper in the middle, powdered with minute brown dots and transverse striae, which lie thickest at the base of the costa ; a small dark brown cell spot; exterior line indicated by a slightly curved row of small brown spots placed on the veins; fringe brownish. Hindwings, like forewings, with the row of spots more distinctly marked. Head, thorax, and abdomen concolorous ; antennae brownish, with the shaft paler. Underside somewhat paler, with the exterior line of spots repeated, and a faint trace of a central dark line, which in the forewings is quite interrupted in the middle of the wing.

Expanse of wings : $34 \mathrm{~mm}$.

One of without locality.

\section{Hygrochroa versicolor sp. nov.}

Forewings purplish grey, interspersed with dull olive, and pale silvery grey shades; costa dull olive; base mixed with fulvous; the lines indistinct, but all rising from oblique whitish costal streaks, which are edged with olive; first line edging a slightly darker basal patch; exterior line whitish interrupted, starting beyond two-thirds of costa, angulated shortly beneath it, then running obliquely inwards to the inner margin before two-thirds; a small dark cell spot, erossed by a scarcely distinguishable angulated olive central shade; submarginal line whitish near costa, apparently merging in the exterior line, but really lost in a large lilac grey patch which occupies the marginal space above the anal angle, and has a small tawny patch above 
it close to the submarginal line; apical region purplish ; fringes dark reddish brown, with some white subapical dashes. Hindwings like forewings, but the whole inner margin olive green; crossed by two lines, the first at one-third, thick, diffuse; the second at two-thirds, finely denticulated, edged externally with paler, and internally with olive. Head, thorax, and abdomen (faded) probably olive green; antennae brown. Underside pale silvery lilac grey, with all the markings rich brown; dusted with blackish atoms, especially along the veins, which are silvery white; some olive costal patches, and a suffusion of mixed olive and reddish grey in the dise, and along the hindmargin of forewings; hindwings with a row of olive patches beyond the second line.

Expanse of wings: $40 \mathrm{~mm}$.

One $\delta$ from Padang.

The hindmargin of the hindwing is straight from the anal angle to the end of the third median vein, but is followed by one deeper excavation than is seen in syringaria Linn.

\section{Leptodontopera gen. nov.}

Forewings ample; costa nearly straight, faintly convex just before apex; hindmargin strongly denticulate, the teeth at the end of the upper radial and third median nervule being larger than the others; upper half nearly vertical, lower half oblique; anal angle nearly rectangular. Hindwings still more deeply denticulate than forewings, the tooth at end of third median the longest; bluntly rounded at the inner angle; more square at anal angle. Antennae of $\delta$ strongly pectinated; of $q$ filiform, simple; palpi short, thick; terminal joint minute; tongue present. Neuration normal.

Type: Leptodontopera decorata Moore (Selenia).

A genus of East Indian species, much less strongly built than Odontopterc Steph., and recalling somewhat Hemerophila Steph.

\section{Leptesthes gen. nov.}

Forewings ample; costa straight for three-fourths, then strongly convex; apex curved, blunt; hindmargin with a short but deep excavation beneath apex opposite the cell, a broad blunt elbow at the end of the second and third median nervules, then oblique and slightly concave to anal angle, which is well marked. Hindwings with hindmargin irregularly dentate, with one much deeper excavation opposite the cell. Abdomen thin ; antennae of the $\delta$ finely and shortly ciliated; palpi short, drooping; tongue present. Neuration normal ; discocellular biarcuate, concave outwards, marked by a double hyaline erescent on both wings; scaling fine and smooth.

Type: Leptesthes megaspila Moore (Lagyra). The resemblance to Hyposidra Guen. is only superficial.

\section{Hyalornis gen. nov.}

Forewings rather narrow; costa straight for three-fourths, then bulged, and convex before apex, which is bluntly rounded; hindmargin strongly concave below apex, vertical to the end of second median nervule, where it is strongly elbowed, thence very oblique and slightly denticulate; anal angle well marked. Hindwings kiteshaped; hindmargin irregular; a blunt projection at end of second median nervule, 
then dentate to the anal angle. Thorax and abdomen thick, the former hairy beneath; $\delta$ antennae short, stoutly pectinated; forehead prominent; palpi thick, porrect, projecting beyond forehead; tongue small; femora hairy. Neuration normal ; the discocellular angulated; the lower arm oblique, marked in both wings by a hyaline angulation.

Type: Hyalornis docta Schaus and Clem. (Focilla).

Akin to the American genus Azelina and its allies.

\section{Fascellina albidiscata sp. nov.}

Forewings uniform deep purple chocolate, with lines darker, as in chromataria Wlk. ; costa at base mixed with fulvous ; central costal marking longer than in chromataria, shallower, its lower margin curved, not angular; discal mark small, pure white, irregularly triangular. Underside : forewings, with the basal half bright yellow, with a few reddish striae, and the first line indicated by a reddish blotch; outer half much as in chromataria ; hindwings yellow, with a broad reddish brown border, which thins out towards the anal angle, containing a round yellow spot at the apex, and a round blackish one in the centre of its inner edge.

Expanse of wings : $34 \mathrm{~mm}$.

One $\delta$ from Padang. Closely related to chromataria, but decidedly smaller, and, besides the colour differences noted above, distinguished by the much shallower excisions of the forewings, and the absence altogether of the apical excision of the hindwings.

\section{Fascellina inconspicua sp. nov.}

Forewings dull purplish grey, with an olivaceous tinge ; the lines as in subsignata Warr., to which it is nearly allied; a darker central shade is visible between the two lines; the paler costal spaces beyond the first and second lines respectively are scarcely visible; the outer line towards the inner margin becomes geminated with a lustrous line in the centre, and this is continued across the centre of the hindwings, and is there preceded by a dark fuscous shade, which broadens out towards the inner margin; the submarginal area of the hindwings is darker. Underside of forewings yellowish, mixed with white in the disc; first line and central shade slightly indicated; second line edged with white, which forms a broad white patch almost touching the hindmargin below the angle; lower part of hindmargin deep brown, becoming blackish brown on the inner margin beyond the line, with a yellowish patch at the anal angle. Hindwings yellow with a straight double dark brown line across the centre, and a fine curved one near the hindmargin, the space beyond washed with lustrous scales.

Expanse of wings : $32 \mathrm{~mm}$.

One $\delta$ from Padang. This species is very close to subsignata Warr., from Sikkim.

\section{Fascellina rectimarginata sp. nov.}

Forewings dark greyish purple, with the base of the costa, a shallow costal triangle, and an apical blotch beyond the exterior line dull silvery grey, speckled with blackish atoms ; first line oblique, parallel to the hindmargin, angulated on the subcostal nervure, deeper purple, edged on the inside with dull silvery ; an oblique diffuse dark purple central shade parallel to the first line; second line fine, dark purple, 
edged externally with lustrous; running at first obliquely outwards from the costa, forming a blunt angle below the costa, then curving inwards, and again bent outwards before reaching the inner margin ; a faintly visible waved lustrous submarginal line; both this and the exterior line start from small white streaks on the costa; a dark purple spot at the anal angle; fringe dark purple. Hindwings, like forewings in colour, with the exterior line reproduced nearly in the centre; it is preceded by a straight deep purple shade. Head, thorax, and abdomen grey tinged with purplish; face yellowish. Underside: forewings, dull greyish tawny; with the costa broadly yellower; the exterior line reproduced and bounded externally with whitish, preceded by a tawny brown shade, the inner edge of which is slightly angulated below the costa; marginal space dull brown, with some silvery white scales from the apex, which form a blotch below the angle of the line. Hindwings deep yellow, with a few transverse striae deep red brown; and two fine curved, slightly irregular red brown lines towards and parallel to the hindmargin.

Expanse of wings: $38 \mathrm{~mm}$.

One $q$ from the Khasia Hills.

This species differs from others of the genus in having no excisions in the hindmargins of the wings except a very slight concavity before the anal angle of the forewings. The inner margin of the forewings and the costa of the hindwings are quite straight.

Callerinnys nom. nov.

I propose to substitute this name for Erinnys Warr., Pr. Z. S., 1893, p. 415, which I find has been already used in Coleoptera.

\section{Callerinnys deminuta sp. nov.}

Forewings yellowish ochreous, thickly dusted with ferruginous; darker, somewhat cinereous, along the subcostal region; first line brown, curved, indistinct; second line faintly sinuous, thick and distinct, near the hindmargin, followed, opposite the cell, by a small dark blotch, which is followed by two smaller marginal blotches. Hindwings the same, with a broad central straight brown line, beyond which the marginal space is rather darker; a small dark cell spot in both wings. Head, face, thorax, and abdomen, sandy ochreous. Underside paler, with the second line darker and thicker.

Expanse of wings : $26 \mathrm{~mm}$.

Two $\delta \delta$ from Padang. Both examples are more or less worn, and the fringes are gone; but they are certainly distinct from any of the Indian species.

\section{Hypochrosis Guen.}

Under Hypochrosis, which, with Achrosis, Guenée makes into the separate family Hypochrosidae, he includes sternaria, hyadaria, festivaria Fab., lycoraria, and jasminaria. Of these hyadaria belongs to Walker's genus Omiza, of which the type is pachiaria Wlk.; festivaria Fab.,=saturaria Wlk., is the type of Walker's genus Celenna; sternaria is equivalent to pyrrhophaeata Wlk., the type of his genus Patruissar; so that Hypochrosis will remain for lycoraria Guen., from Borneo, and the as yet unidentified jasminaria from India. 
Omiza nundata Feld. (Reise Nov., Pl. CXXXIII., fig. 10 f).

Forewings dull reddish brown, thickly covered with darker freckles, basal area slightly darker, bounded by an ill-defined line; two blackish costal triangles on either side of the middle. Hindwings the same colour, but with the costal third pure dull yellow. Head, thorax, and abdomen concolorous with ground colour. Underside deep orange; the forewings with an aggregation of brown transverse striae along the dise.

Expanse of wings: $36 \mathrm{~mm}$.

One $q$ (marked $\delta$ ) from the Moluceas.

The insect is unlike any other Omiza in markings, but agrees in the pale costa of the hindwings. The palpi are damaged, and the antennae entirely destroyed.

Patruissa sternaria Guen. ocellata aberr. nov.

In this form the outer edge of the central band is not indented, so that what in the type form is the limit of the indentation, becomes a large discal ocellus. The rest of the wings and underside precisely the same as in the type.

One $\delta$ from Padang, one $q$ from Assam, accompanying a $\delta$ of the type form from each locality.

\section{Omizodes gen. nov.}

Forewings broad and short; costa curved at base and before apex; apex rounded; hindmargin faintly curved, slightly oblique; anal angle rounded. Hindwings broad, with rounded hindmargin, which is slightly indented before the prominent anal angle. Antennae of $\delta$ broadly pectinated to apex; palpi very short; tongue ?absent; forehead slightly prominent; hind tibiae of $\delta$ with four spurs. Neuration: forewings, cell more than half the length of wing; its ends very strongly inclined towards each other; first median nervule at seven-eighths, second just before end, third from end of cell, strongly arched at base; radials as usual. Hindwings : costal approximated to subcostal for two-thirds of cell; two subcostals from upper angle; first median at about three-fourths, second some little distance before end of cell ; third from the end. Scaling thick and dense.

Type: Omizodes ocellata sp. nov.

\section{Omizodes ocellata sp. nov.}

Forewings pale dull ochreous olive; first line marked by a black costal spot, and three small dark dots, one in the cell, another on the submedian fold, and the third above the inner margin; exterior line from just before apex to before anal angle, bent inwards in the middle, and only defined by the difference in tint, the space between it and the first line being darker olive; sometimes a dark spot or two on the course of the line, and a few scattered dark scales in the hindmarginal region; a semitransparent brown-edged discal spot; fringe concolorous. Hindwings paler, yellower, with a reddish oval cell spot, a few dark atoms, and on the inner margin the beginning of a geminated line. Thorax and abdomen concolorous with wings; face, vertex, and antennae dark brown; palpi reddish orange. Underside rich deep yellow with the brown markings brighter; costa of forewings brown spotted, and an oblique brown apical streak. 
Expanse of wings: $40 \mathrm{~mm}$.

Three $\delta$ o from South Africa.

Both wings are sometimes thickly dusted with fuscous atoms.

\section{Heterolocha incolorata sp. nov.}

Forewings very pale testaceous, tinged with olive, especially along the costa; thickly dusted with coarse olive and lilac scales; base of wing more thickly dusted; basal line curved, but very faint; second line dull olive or rosy olive, nearly parallel to hindmargin, but slightly nearer at the costa than on the inner margin; an indistinct ocellus on the discocellular, edged with olive. Hindwings the same, with a straight olive or rosy olive line from above anal angle to above apex, not always reaching the costa. Head, thorax, and abdomen concolorous with ground colour, and mottled with darker. Underside whiter, with the mottlings and markings darker and more distinct.

Expanse of wings: 26 to $32 \mathrm{~mm}$.

Two $\&$ from Subathu.

This is the Indian form which answers to Butler's niphonica from Japan, but it is paler and more transparent. The forewings are acute, and their hindmargin oblique.

Heterolocha stulta Butler notata aberr. nov.

Wings dull olive yellow, glossy, with both lines and the ocellus marked in dull rosy olive; but examples occur in which these markings become very faint, and thus connect the form with the type.

\section{Heterolocha subroseata sp. nov.}

Forewings yellow in both sexes, tinged with olive, and sparsely sprinkled with purplish striae; costa dotted with purplish, with a larger purplish spot at one-fourth indicating the origin of the basal line; a smaller spot on the inner margin at its end; its course can be traced indistinctly by darker scales; a dull olive yellow ocelloid discal spot, edged with darker; an olive yellow or rosy oblique fascia from inner margin at two-thirds to apex; the inner edge sometimes scalloped and edged with dark purplish dots; apex occupied by a purple spot; fringes deeper yellow, olive tinged. Hindwings the same, but without any basal line. Head, thorax, and abdomen yellowish; antennae brownish. Underside brighter yellow, with the mottlings and markings bright rosy purple.

Expanse of wings: 34 to $36 \mathrm{~mm}$.

Two $\delta \delta$, one $q$ from Japan.

This form answers to Walker's falconaria from India. The $q q$ can be distinguished from the larger $q+$ of aristonaria by the straight hindmargin of the hindwings. In one of the $\delta \delta$ the apical patch is quite wanting.

\section{Prionia multidentata sp. nov.}

Forewings dull ochreous, entirely covered with dark fuscous striae and blotches, which in places become confluent; transverse lines blackish, starting from dark blotches on costa; first from beyond one-third irregularly dentate to inner margin at one-fourth; second at two-thirds strongly and irregularly dentate to inner margin shortly before anal angle; the two lines being therefore twice as far apart on inner 
margin as on costa; an oblique brown line from before apex to the middle of the hindmargin; fringe dark brown. Hindwings yellow; on inner margin whitish, freckled with fuscous; anal angle thickly freckled with coarse fuscous dots and a dark fuscous dash; hindmargin also slightly freckled, but more finely; fringe mottled pale and dark fuscous. Head, thorax, and abdomen grey mottled with fuscous; palpi, antennae, and top of face dark fuscous; lower part of face yellowish. Underside of forewings dull yellowish, suffused towards hindmargin with rosy cinereous; the lines indistinct. Hindwings orange with hindmargin rosy cinereous.

Expanse of wings: $32 \mathrm{~mm}$.

One $q$ from Nias.

\section{Zomia purpurascens sp. nov.}

Forewings purplish slate colour, the markings velvety black; basal line thick, subangulated below the costa ; exterior line the same, forming first a blunt angulation, and below it a rounded sinus, outside of which it thins out for a short distance ; outside of first line and inside of second indistinctly and partially edged with tawny ; a dark cell spot. Hindwings as in incitata Wlk., bright yellow, unfreckled; with a dark cell spot, and the anal angle and inner margin purplish grey, the former with a darker dash. Head, thorax, and abdomen purplish grey. Underside of forewings dull blurred yellow, with the lines showing indistinctly; the cell spot strongly marked, and the whole apical region beyond the second line purplish grey; underside of hindwings bright yellow, with the cell spot, the dash at the anal angle, and a few scattered submarginal dots purplish.

Expanse of wings : $32 \mathrm{~mm}$.

One $\delta$ from Engano, smaller than incitata, and very much darker.

\section{Sicyodes gen. nov.}

Like Sicya Guen., which is an American genus, but with the $f$ antennae pectinated, though more shortly than in the $\delta$. The species are all South African.

Type: S. cambogiaria Guen. (Sicya).

\section{Nepheloleuca semiplaga sp. nov.}

Forewings canary yellow, slightly elbowed in the middle of the hindmargin, costa paler, much spotted with dark brown; surface sparsely strewn with dull olive transverse striae; first line rather oblique outwards, slightly sinuous, dull olive; costal spot nearly semicircular, dull whitish, edged with brown; from it runs a dull olive line, curving slightly outwards to the anal angle ; it is preceded on the inner margin by a short upright blotch, edged internally with darker; cell spot, blackish, well defined. Hindwings like forewings, with a curved and denticulate dark white-edged line, as in complicata Guen., followed immediately by a dull rufous shade, which starts from the costa with the line itself, is broadest behind the tail, and does not reach the anal angle; tail blunt, tipped with reddish brown, and with an oblong black mark in front; fringe line and fringes reddish. Head, face, thorax, and abdomen concolorous. Underside like upper, without mottlings; the outer line marked on both wings; the hindwings with a red brown anal patch.

Expanse of wings: $34 \mathrm{~mm}$.

One of from Corcovado. 


\section{Autophylla gen. nov.}

Forewings with the costa unusually gibbous from base to shortly before apex, then shallowly concave; apex produced as a rather long blunt beak; below which the hindmargin is first very strikingly concave, and then as strongly convex, forming a broad blunt elbow as far as the third median nervule, where it is once more concave and obliquely sinuous to the anal angle, which is well marked. Hindwings with hindmargin simply rounded, and interior angle well marked. Abdomen (of $q$ ) short, and stoutish, with projecting ovipositor; forehead flat; antennae fine, filiform ; palpi very short; tongue weak. Neuration: forewings, with cell extending beyond the half of the wing ; first median at three-fourths, second just before angle, third from lower angle of cell ; lower radial from centre of the discocellular, which is inangulated; upper radial from upper angle of cell ; last three subcostals on a common stem, the fifth running parallel to upper radial into the blunt elbow, the fourth into the concavity below the apex, and the third into the apex itself; the first and second are invisible, and perhaps, owing to the peculiar shape of the costa, absent. Hindwings with the costal approximated for a little way to the subcostal, then arching away; the two subcostal nervules separating before the end of cell; medians as in the forewing; discocellular also inangulated, as in forewing; scaling dense and close.

Type: Autophylla pallida sp. nov.

The two $q q$, which $I$ have had before me in describing the genus, are almost certainly from South America, as they bear a great superficial resemblance to the species of the genus Phyllodonta Warr., and other allied genera from that locality. They were, however, labelled, "Either from Australia or South America." The peculiar outline of the forewings will at once distinguish them ; it may be best compared with the profile of a snail's head, with the horns somewhat retracted. They also have a superficial likeness to Hyposidra Guen.

\section{Autophylla pallida sp. nov.}

i. Forewings ochreous suffused with pale olive, and thickly sprinkled with blackish atoms; first line diffuse, indistinct, rather a shade than a line, but marked by a small dark dot on each vein; second line dull olive, geminated, with a paler thread between, running straight from the tip of the apex to beyond the middle of the inner margin ; at the apex it is edged externally with a white line, which ends in a small white spot; the inner-marginal third is less suffused with olive than the rest of the wing; but above the anal angle is an obscure olive shade. Hindwings paler, with no suffusion; a central straight line, which is the continuation of the second line of the forewings, and another curved, submarginal. Head, thorax, and abdomen ochreous mottled with darker. Underside paler, more yellowish ochreous, spotted with fuscous olive; the lines darker; the second line in the hindwings preceded by a row of spots, and with the discocellular marked in brown; forewings more suffused with olive and grey.

Expanse of wings: $62 \mathrm{~mm}$.

Two $i f$ from ? South America.

Lobopalta gen. nov.

Forewings narrow ; costa uniformly arched from base to apex, which is blunt, not produced; hindmargin projecting slightly outwards for only half the width of the wing, then forming a broad blunt prominence, succeeded inwardly by a similarly 
shaped incision, and thence curving into the convex inner margin without producing an anal angle at all. Hindwings elongate, irregularly margined; both the angles well rounded; a minute tooth of scales at the end of the two subcostals and first median, and a broad, irregularly bilobed projection opposite the second and third median nervules, the lower lobe the larger and blunter. Forehead, palpi, antennae, and hind tibiae of $\delta$ as in Phyllodonta. Neuration the same, only that the median nervure of the forewings is at one-third from the costa, thereby making the cell much narrower than in Phyllodonta, and the projecting upper part of the hindmargin proportionally much shorter.

Type: Lobopalta latrata Guen. (Azelina).

\section{Phyllodonta gen. nov.}

Forewings ample; costa gradually curved from base, and very slightly concave before apex, which is produced as a short blunt point; hindmargin beneath it in the $\delta$ running straight, and in the $q$ slightly curved, in an outward direction, for twothirds the breadth of the wing, where it forms a short blunt projection similar to that at the apex, and within it a clean semicircular excision, thence curving inwards to the anal angle, which is more pronounced in the $q$ than in the $\delta$; inner margin somewhat convex. Hindwings broad, with the hindmargin similar to that of the forewings, but without the apical projection. Forehead prominent; palpi with basal joint laxly scaled; second joint with appressed scales, slightly ascending, third joint short, blunt, thrown forward at an angle with second; tongue present; antennae simple in both sexes; hind tibiae of $\delta$ uniformly swollen throughout. Neuration : forewings, cell more than half the length of wing; discocellular with upper arm vertical; the lower slightly curving outwards; the median vein nearly in the centre of the wing; first median nervule only a little beyond the middle, inclined downwards, and running into hindmargin below the rounded excision at four-fifths from the apex ; second median from shortly before the lower angle, third from the angle of cell, and much arched upwards in its course; lower radial from angle of discocellular, upper radial from top angle of cell, both drooping a little towards the hindmargin; last three subcostals on common stem, the fifth curving downwards into hindmargin below apex; the fourth into apex itself; first and second apparently free, but very closely approximated. Hindwings like forewings, the first subcostal starting before the end of cell.

Type: Phyllodonta caninata Guen. (Azelina).

The genus has nothing really in common with Azelina.

\section{Phyllodonta furcata sp. nov.}

Forewings testaceous, sometimes much suffused with fuscous, and dusted with darker atoms; first line at one-third, brownish olive, somewhat wavy ; an indistinct darker central shade; second line brown, geminated; rising at three-fourths and sharply angulated close to the apex, then running to the inner margin just before the anal angle, where it is slightly curved, and gives off an arm which runs into the angle itself. Hindwings with a curved central and denticulated line, followed closely by a straight but slightly wavy double line, beyond which the hindmargin is darker; fringes of all the wings dark brown. Head, thorax, and abdomen concolorous with wings. Underside testaceous, mottled with darker, with all the markings very indistinct, and the apex of forewing whitish. 
Expanse of wings: $44 \mathrm{~mm}$.

Two $f q$, one much darker than the other; the paler one from the Felder collection without locality, the darker example from Corcovado.

\section{Phyllodonta informis sp. nov.}

Wings fawn colour, slightly ochreous tinged, and dusted sparsely with black atoms; an indistinct dark basal line; an equally indistinct curved central shade, passing over a minute black cell spot; exterior line angulated below the costa, starting from a dark brown oblique costal spot, and after the angulation running straight to the inner margin before the anal angle, indicated in the main by black points on the veins; costa with some dark fuscous strigae, and a small dark cluster on the hindmargin above the indentation. Hindwings paler, with a broadish mixed tawny and pale central shade, and an indistinctly denticulated tawny submarginal line. Head, thorax, and abdomen concolorous. Underside paler, with the markings equally indistinct; the exterior lines in both wings marked by black points on the veins; hindwings with an oval reddish brown blotch near the middle of the inner margin.

Expanse of wings : $36 \mathrm{~mm}$.

One $\delta$ from Tijuco. Differs from the other species by the shallow blunt incision in both wings.

\section{Rhomboptila gen. nov.}

Forewings elongate; costa uniformly arched from base to apex, which is bluntly rectangular; hindmargin for nearly half the width of wing running straight and slightly outwards, where it forms a more or less prominent protuberance, varying from a mere elbow to a decided tooth, according to the species, then incurved to the anal angle, either plainly or slightly or very deeply crenulate. Hindwings kite shaped, with a more or less prominent projecting point in the centre of the hindmargin, the hindmargin itself on either side being variously crenulated. Forehead hardly projecting; palpi shortly rostriform; tongue present; antennae simple in both sexes. In the $\delta$, near the base of the forewings occur two bladdery scaleless patches, above and below the submedian fold. Neuration as in Lobopalta Warr.; the cell, however, is hardly half as long as the wing; the median vein lies little above the centre, and is slightly thickened and upcurved beyond the base above the bladdery space.

Type: R. brantsiata Snell.

\section{Rhomboptila delicata sp. nov.}

Forewings pale testaceous, suffused with olive and tawny, and finely dusted with blackish atoms; basal area palest, edged by a fine irregularly dentate and wavy black line at one-third; second line lustrous lilae grey, finely edged internally with darker, dentate, wavy, from two-thirds of inner margin to costa before apex, near which it is angulated; discal spot black; just beyond it is a faint wavy olive central shade, the space between which and the basal line is dull tawny, while that between it and the external line is dull olive; costa narrowly white, more broadly immediately before apex; an indistinct submarginal line indicated by blackish dots and blotches; fringes darker near the anal angle. Hindwings with the basal half pale testaceous, coarsely mottled with darker; cell spot large, round, black; marginal half dull olive, 
separated from the basal half by a continuation of the exterior line of the forewings, which in this case is neither wavy nor dentate; fringe all dark. Head, thorax, and abdomen pale testaceous; palpi and face dark brown. Underside yellowish ochreous, coarsely mottled with dark fuscous; discal spots distinct black; second line on forewings white, on hindwings black; marginal space in both wings fulvous, except near the centre of the hindwings, where there is a yellow patch; two blackish spots below the apex of the forewings.

Expanse of wings : $38 \mathrm{~mm}$.

One of from Santos.

Intermediate between brantsiata Snell. and siccifolia Warr., having the prominent central tooth of the hindwings of the former, and the less indented margins of the latter.

\section{Rhomboptila siccifolia sp. nov.}

Forewings pale wood colour, sometimes much suffused with olive, in which case the markings are less distinct; these consist of a dark wavy basal line, diffuse internally, preceded in the basal area by two or three dark spots; an ill-defined darker central shade beyond the small dark cell spot; second line fine, oblique, at four-fifths; angulated near the costa, and slightly eurved outwards before inner margin; followed in the marginal space by two dark clouds. Hindwings paler, not suffused, with a small dark cell spot, and a straight dusky line from inner to anal angle; fringes of both wings reddish brown. Head, thorax, and abdomen wood colour; face yellowish; palpi and antennae brown. Underside dull straw colour, dusted with fuscous, with the external line in both wings brown, and a cinereous cloud before the hindmargin of the forewings.

Expanse of wings: 38 to $42 \mathrm{~mm}$.

Three $\delta \delta$ from Santos and S. Paolo.

Anisogonia gen. nov.

Forewings ample; costa nearly straight in the middle, more abruptly arched from base, and before apex; apex in $\delta$ blunt, scarcely projecting; in $q$ forming a small subacute point; hindmargin curved, with a slightly irregular outline, caused by uneven projections opposite the veins, and with a searcely perceptible elbow above the middle; $q$ with the hindmargin below the subfalcate apex running slightly outwards for not quite half the width of the wing, where it forms a similarly shaped toothlike projection to that at the apex, followed inwardly by a deep circular incision between the second and third, and a shallower one between the first and second median nervules, this latter being thereby flanked by two smaller teeth; anal angle as in $\delta$, not definitely marked; inner margin hardly convex. Hindwings full, with hindmargin rounded, with a very faint projection in centre. Forehead slightly prominent; palpi porrect, rather drooping; the second joint broad, stout; the third short, conical; tongue present; antennae of $q$ simple; of $\delta$ pectinated to apex. Hind tibiae of $\delta$ long, scarcely thickened, with two pairs of long, rather distant, spurs. Neuration: forewings, cell a little more than half as long as the wing; discocellular inangulated; first median nervule from two-thirds, second close before end, third from end of cell; lower radial from angle of discocellular; upper from upper angle of cell; five subcostals on a common stem, rising shortly before end 
of cell. Hindwings as in forewings, but the costal is approximated to the subcostal for almost half the length of the cell.

Type: Anisogonia deustata Feld. (Paragonia).

N.B.-Two of from Chili, like all the other typical of in markings, differ entirely in the contour of the wings; that of the forewings resembling the $f$ in having a distinctly projecting apex and elbow in the hindmargin, with slight but distinct crenulations throughout; while that of the hindwings is more deeply crenulate, and has a projecting central tooth.

\section{Astatomorpha gen. nov.}

Forewings narrow, elongate; costa strongly curved from base to apex; apex produced, blunt; hindmargin incurved beneath apex, then vertical to the middle of the wing, where it slants suddenly basewards, almost in a line with inner margin, the anal angle being indicated only by the stoppage of the fringe. Hindwings narrow, appearing as if a third of them had been cut away from the inner margin; hindmargin almost vertical, slightly curved; anal angle blunt, prominent. Eyes large; palpi upeurved; antennae $\delta$ thick, serrate-ciliate; hind tibiae greatly enlarged; abdomen puffed out towards apex, with two lateral tufts of hair. Neuration: cell not quite half as long as wing; discocellular in forewing, curved obliquely outwards; first median nervule at three-fourths, second close before, third from end of cell; lower radial from middle of discocellular; upper from upper end of cell, both eurving parallel to costa; last four subcostals on common stem, rising just before the end of cell ; first subcostal (apparently) free. Hindwings with discocellular slightly angulated, the upper arm vertical, the lower oblique; costal approximated shortly to subcostal not far from base; the two subcostal nervules from upper end of cell; medians as in forewing.

Type: Astatomorpha virgultaria Feld. (Polla).

Distinguished, at a glance, by the shape of the wings, by the lateral tufts of the abdomen, and the $\delta$ antennae.

\section{Euclysia gen. nov.}

Forewings with costa evenly arched from base to apex; apex blunt; hindmargin with an elbow or angle at the end of the third median, above which it is vertical, and below oblique; anal angle well marked; hindwings as in Prochoerodes, with a decided tail in the middle, the hindmargin straight on either side, and the anal angle square. In the $q$ the apex of forewing is more produced, and the hindmargin beneath it slightly incurved. Antennae simple in both sexes; tongue present; palpi short, stout, upturned, and closely appressed to face; second joint broad; third very small; hind tibiae of $\delta$ slightly enlarged with two pairs of short spurs. Neuration normal. Scaling thick and glossy; markings consisting of two sinuous transverse lines, the outer one convex inwards, as in Simopteryx Warr.

Type: Euclysia columbipennis Wlk. (Clysia).

\section{Euclysia restricta sp. nov.}

Like Euclysia columbipennis Wlk., but the forewings darker grey, with more numerous transverse dark striae; the rose coloured patch beyond the second line is much reduced in size, being limited to two small round reddish blotches.

One + , two $\delta \delta$ from $S$, America, 
Herbita Wlk. (xx., p. 212).

To Walker's description of the genus should be added "Underside of the hindwings densely woolly in the $\delta$, partially so in the.$+ "$

Polla H.S.

Under Polla H. S. includes the species indicated by his figures $195 ; 416$; 417,$418 ; 485$. But of these 195 is a Fidonia, and is so named on the cover; 416 is an Acrosemia; while 485 is an Oxydia. Polla may therefore be taken as the generic term for praelataria and its allies. The $\delta$ antennae are finely ciliated, till near the top; the hindmargin of the hindwings is nearly straight.

Eutomopepla gen. nov.

Forewings with costa well arched, from base to apex, which is blunt, and rectangular; hindmargin, for half the breadth of the wing, straight, and running slightly outwards, there forming a stout, blunt tooth, then incurved to the anal angle, with three small crenulations; anal angle well marked; inner margin straight. Hindwings kite shaped, with a blunt tooth in the middle of the hindmargin, as in Rhomboptila, but the anal angle squarer; the margin from the angle to the central tooth straight; above the tooth with a distinct excision, containing a small tooth at the end of the second, and bounded by a larger tooth at the end of the first subcostal nervule. Forehead shelving, projecting below; palpi shortly porrect; tongue present; antennae of $\delta$ thick, with a double row of short stout ciliations. Neuration as in Rhomboptila, but the forewing is entirely without bladdery patches.

Type: E. annulipes Feld. (Semiothisa).

\section{Trotopera gen. nov.}

Forewings with costa arched at base, very slightly concave before apex, which is produced as a rather prominent subacute point; hindmargin slightly hollowed out immediately below the point, then running obliquely outwards with slight crenulations to the middle of the wing; there forming a strong projecting tooth, and passing by a strong curve containing three decided crenulations to the anal angle, which is rectangular. Hindwings kite shaped, with the anal angle well marked, the hindmargin thence to the central projecting tooth strongly crenulate, and less so above the tooth. Forehead flat; palpi porrect, the last joint drooping; tongue present; antennae in $q$ filiform. Hind tibiae of $\delta$ very much swollen and enlarged. Neuration : forewings, cell not half as long as wing; discocellular nearly vertical; first median nervule at three-fourths; second at one-third from the end of cell; lower radial from a little above the centre of the discocellular; upper radial from top end of cell; the median nervure exactly in centre of the wing. Hindwings with the costal approximated to the subcostal, at a point only, not far from base; the two subcostal nervules from top end of cell; the last two medians from the lower end, and the first median at three-fourths.

Type: T. maranharia Feld. (Metrocampa).

The type of maranharia in the Felder collection is a $\delta$, but without antennae, and with the wings so patched and mended that all the crenulated outline is gone. The comparison of the $\delta$ antennae may not improbably show it to be nearly related to Eutomopepla. 


\section{Simopteryx gen. nov.}

Resembling Cimicodes Guen., but the antennae of the $\delta$ are pectinated, instead of being simple; the transverse lines, instead of running vertically, are directed obliquely inwards.

Type: S. torquataria Wlk. (Cimicodes).

\section{Simopteryx (?) cervina sp. nov.}

Wings fawn coloured, with a slight pinkish tinge, dusted with black atoms, without any markings except, in the forewings, the commencement on the costa of two dark transverse lines, angulated on the subcostal nervure, and not plainly traceable across the wing, and, in the hindwings, an indistinct central line. Head, abdomen, and underside alike.

Expanse of wings : $28 \mathrm{~mm}$.

One $\&$ from Madagasear.

\section{Cratoptera apicata sp. nov.}

+. Forewings pale yellow, quite sparsely dusted with fuscous atoms; the costa broadly and diffusedly reddish brown, with white dashes at intervals along the extreme edge ; first line brown, diffuse, bluntly angulated a little above the middle ; second line from the apex itself runs straight to the middle of the inner margin; a dark spot on costa at two-thirds; cell spot minute, black; a submarginal shade of indistinct brown blotches. Hindwings with second line produced straight across it; a submarginal interrupted band of brown blotches, the two central the largest and nearest the centre. Underside bright yellow, with the lines of the forewings thick, red brown ; a red brown vertical irregular submarginal cloud; hindwings with central line and submarginal shade pinkish orange. Head, thorax, and abdomen yellow.

Expanse of wings : $52 \mathrm{~mm}$.

One $\&$ from British Guiana.

\section{Eusarca Hüb.}

The American species of Caberodes Guen.-all, that is, but the first, which is an Indian species, and will stand as type of Caberodes,- - differ in no single point from his previously described Apicia; but this name will not stand, for in his Exot. Schm., i., Lep. 5, Geom. 1, 1 A. b. Hübner uses the generic term Eusarca for his own species confusaria, which thereby becomes the type. The subsequent use of Eusarca by $\mathrm{H}$. S., etc., for the jacularia group is consequently erroneous.

The species of this genus are very closely allied, and at the same time variable inter se, so that their accurate differentiation is not at all easy, and may require future modification.

\section{Drepanodes Guen.}

Depranodes Guen., Phal., i., p. 66, group 1 (part).

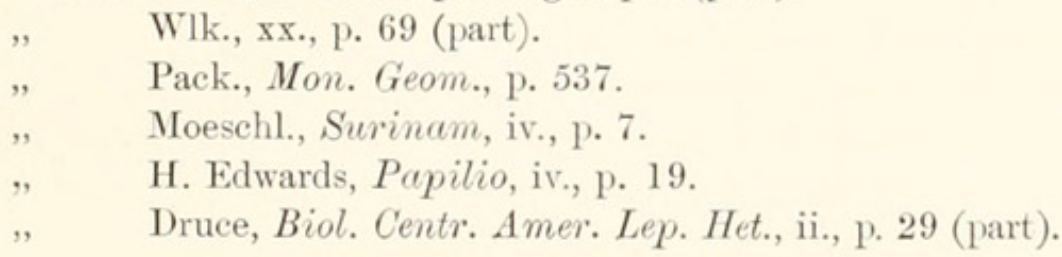


? Polla H. S., Auss. Schm., fig. 485.

A picia Wlk., xx., p. 111.

? Crocopteryx Guen., Phal., i., p. 72.

Type: D. maculata Stoll.

I restrict Drepanodes to Guenée's first group, viz., those in which the $\delta$ o have simply pubescent antennae.

\section{Syssaura Hüb.}

Syssaura Hüb., Zutr., ii., p. 13, figs. 247, 248.

Drepanodes Guen., Phal., i., p. 66, group ii.

, Wlk., xx., p. 69 (part).

, Druce, Biol. Centr. Am. Lep. Het., ii., p. 29 (part).

Microsema H. S., Auss. Schm., pp. 64, 83, fig. 482.

Drepana Wlk., vii., p. 1761.

Hyperythra Wlk., xx., p. 125.

Hyposidra Butler, Pr. Z. S., 1878, p. 492.

Type: Syssaura drepanula Hüb.

Distinguished by the elongated, very faleate forewings, and the short straight pectinations of the $\delta$ antennae.

Halesa Wlk. (xx., p. 211).

? Falcinodes Guen., Phal., ii., p. 30.

Falcinodes Snell., Tijd. v. Ent., 1874, p. 61.

Druce, Biol. Centr. Am. Lep. Het., ii., p. 32.

Walker says of Halesa: " Exterior border of forewings broadly excavated on each side of the middle, where it is slightly angular ; exterior border of hindwings slightly scalloped and dentated." Of Falcinodes Guenée says, "Wings entire. Hindwings rounded, with the anal angle slightly produced, but without excavations. Independent of the forewings attached to the subcostal." Snellen, in giving the neuration of his gonodontaria, says of forewings, "five from centre of the discocellular, 6-10 stalked." For the present, not having seen covvinaria Guen., I prefer to keep Falcinodes Guen. and Halesa Wlk. distinct, being of opinion that the former genus does not truly belong to the Geometridae.

\section{Merocausta gen. nov.}

Forewings rather short; costa faintly curved; apex blunt; hindmargin oblique, faintly arched. Hindwings broad, with well rounded hindmargin. $\delta$ antennae strongly pectinated, the pectinations being themselves finely pubescent ; palpi short, upturned, third joint minute; tongue present. Hind tibiae of $\delta$ flattened and thickened, with two pairs of spurs, the second pair quite short. Neuration normal; scaling smooth and fine; markings consisting of two irregular transverse lines enclosing a slightly darker central area.

Type: Merocausta elfina sp. nov.

From the markings and coloration of the underside the genus appear to be akin to Pyrinia Hüb., from which it is separated by the different shape of the wings, and by the antennae. Druce's Gynopteryx mynes, though twice the size of $\boldsymbol{M}$. elfina, evidently belongs here, and possibly his Apicia atia. 


\section{Merocausta elfina sp. nov.}

Forewings ochreous whitish, dusted and mottled with olive brown atoms and strigae, and suffused with the same tint in the central area between the two lines and towards the hindmargin ; basal line beyond one-third, thick, reddish brown ; angulated beneath the costa, then running to inner margin parallel to hindmargin; second line at four-fifths, olive brown, forming a prominent blunt tooth towards hindmargin below costa, then running irregularly sinuous inwards, and approaching the first line on the inner margin; hindmargin below apex and above anal angle red brown, as are the fringes: apex itself with a small pale spot; submarginal line indicated by black dots on the veins. Hindwings the same, but with only the outlines of a central band : fringes and whole hindmargin narrowly olive brown, with the row of dots as in forewings, but less distinct. Underside yellow, except towards apex of forewings, which is whiter, with the markings deeper brown. Thorax, abdomen, and underside with legs ochreous white, spotted with brown; vertex, antennae, top of face, and tips of palpi brown. This description is made from a quite fresh specimen from Corcovado; the others, which seem to be all more or less worn, have lost the deeper brown tint, and are dirty whitish, with dull olive markings only. These are from Santos and S. Paolo.

Expanse of wings: $22 \mathrm{~mm}$.

Eight $\delta$ o

\section{Crocopteryx Guen.}

At p. 72, vol. i., Guenée proposed this genus for a group of species, one of which he himself mentions as having been figured by Hiibner under the generic name of Pyrinia. This name must, therefore, supersede Guenée's. In the diagnosis Guenée gives "antennae long, simply pubescent"; but after the description of erythrocephalata. p. 73, says, "This is the only one of the genus, as far as is known at present, of which the antennae (ठ) are pectinated. For this species, then, which thus differs from the rest, I take it that Crocopteryx Guen. should be retained, with the correction "antennae pectinated."

\section{Patalene H. S.}

Patalene H. S., Auss. Schm., p. 80, fig. 199.

Drepanodes Guen., Phal., i., p. 66 (part).

„, Wlk., xx., p. 69 (part).

", Druce, Biol. Centr. Am. Lep. Het., ii., p. 29 (part).

, Pack., Mon. Geom., p. 537 (part).

" $\quad$ Gr. and Rob., N. Y. Ann. Lyc. N. H., vii., Pl. XV. a, figs. 2, 3.

Syssaura Gr. and Rob., , , , , , fig. 1.

Type: Patalene falcularia Sepp.

Distinguished from Syssaura Hiib. by the fully pectinated antennae of the $\delta$, and the less falcate forewings.

Pyrinia brunneata sp. nov.

Forewings dull smoky fulvous, dotted and suffused with darker fulvous; the markings blurred and indistinct; these consist of a darker basal patch, an angulated inner line at one-third, another angulated exterior line at two-thirds, and an irregular 
border along the hindmargin. Hindwings the same, with only a straight central fuscia and a broader marginal one. Head, thorax, and abdomen dull fulvous. Underside dull yellow, with dull reddish brown spots and markings; these last the same as on the upperside, but quite distinct and concise.

Expanse of wings : $22 \mathrm{~mm}$.

One $\delta$ from the Felder collection, collected by Bates, from the Amazons.

Pyrinia fulvata sp. nov.

Forewings, dark fulvous, deeper towards hindmargin; costa dotted with dark brown and pale ochreous; a faint curved lustrous line at one-third, and an irregularly dentate sinuous line from the costa before the apex to the inner margin at two-thirds. Hindwings with costa and base paler fulvous, a central straight distinct lustrous line, and a faint lustrous suffusion before the darker marginal border. Head, thorax, and abdomen all fulvous. Underside deep dull yellow, mottled with dark fulvous; marginal region of forewings wholly dark fulvous, the second line starting from the costa as a broadish lustrous lilac streak. Hindwings with two straight, narrow, central fascia, and one broader, submarginal, dark fulvous one; fringe of forewings beneath dark brown; of hindwings, fulvous.

Expanse of wings : $26 \mathrm{~mm}$.

One $\delta$ from South America.

Pyrinia signifera sp. nov.

Forewings reddish chestnut, slightly olive tinged, and very finely dusted with dark atoms; costa paler, dotted with black, with a larger black mark before apex; first line lustrous, dull lilac, shaped like a bracket $\{$, followed by a darker shade in the disc ; second line at four-fifths, parallel with the hindmargin, brighter lilac, preceded on the costa by a short blackish streak. Hindwings with costa pale yellowish, with a central cross line answering to the exterior line of forewings; fringes of both wings with the tips yellowish. Head, thorax, abdomen, legs, and antennae reddish. Underside of wings bright yellow, dusted with reddish. Forewings, with inner margin shining whitish, above which is a diffuse shade of small purplish streaks; a purple spot at the end of the cell, and a lustrous thick lilac line indicating the exterior line above, followed by a reddish brown blotch at anal angle. Hindwings with an orange tawny marginal border.

Expanse of wings : $26 \mathrm{~mm}$.

One $\delta$ from Novo Friborgo.

Curbia (Wlk. MS.) gen. nov.

Crocopteryx Guen., Phal., i., p. 72.

Pyrinia Wlk., xx., p. 82.

, Swinh., Cat., No. 3193.

Ephyra Wlk., Journ. Linn. Soc., iii., p. 194.

Curbia Wlk. M.S.

Type: Curbia martiata Guen. (Crocopteryx).

Differs from the American genus Pyrinia Hüb. in having the third joint of the palpi much longer and drooping; the hind tibiae of the $\delta$ not thickened; the fringes of the wings chequered, yellow and blackish. The single species is East Indian and Malayan. 


\section{Meticulodes obfuscata sp. nov.}

The same size and shape as cyclodaria Feld. and xylinaria Guen., but the ground colour dark fuscous grey instead of ochraceous bone colour; cell spot of forewings whitish, like that of cyclodaria, but not so large; inner basal line of forewings further from the base, and angulated decidedly in the middle.

One $\delta$, from S. America.

\section{Prionotetracis gen. nov.}

The genus differs from both Tetracis Guen. and Ctenotetracis Warr. in having the $\delta$ antennae strongly serrate; neither simple, as in Tetracis, nor pectinated, as in Ctenotetracis.

Type: P. latistrigata Warr. ined.

\section{Isochromodes gen. nov.}

Akin to Sabulodes Guen. and Certima Wlk., but at once distinguished by the $\delta$ antennae which are armed with short fascicles of cilia. The species included in it are of smaller size, and more delicate build and markings.

Type: Isochromodes extimaria Wlk. (Apicia?).

\section{Heteroctenia gen. nov.}

Iike Sabulodes Guen. and Certima Wlk., but with the $\delta$ antennae strongly pectinated; it thus bears the same relation to those genera that Ctenotetracis Warr, does to Tetracis Guen.

Type: Heteroctenia pectinicornata Guen. (Sabulodes).

\section{Eupsamma gen. nov.}

Forewings ample; costa hardly curved; apex square; hindmargin slightly oblique, with a faint elbow at end of third median nervule; anal angle distinct, but rounded. Hindwings broad, with hindmargin rounded, but slightly elbowed at the end of third median. Thorax hairy; forehead projecting below; antennae (ठ) strongly pectinated; palpi short, hardly reaching beyond forehead; tongue present. Neuration normal.

Type: E. pulverosa sp. nov.

The genus is related to Descoreba Butler from Japan, and the American genus Cirsodes of Guenée. It is broader winged than either, and differs from both in having a slight elbow in the hindmargin of both wings.

\section{Eupsamma pulverosa sp. nov.}

Wings sandy ochreous, coarsely dusted with fuscous ochreous atoms; a fine dark brownish line from apex of forewings to middle of inner margin of hindwings, edged externally with paler; a dark cell spot in each wing, and in the forewings a brownish collection of atoms beyond the line between the second and third median nervules. Hindwings paler at base. Head, face, thorax, and abdomen yellowish ochreous, undusted with atoms. Underside paler; the markings consequently a little more distinct.

Expanse of wings: $48 \mathrm{~mm}$.

1 o from Knysna in the Felder collection. 
Xyloscia gen. nov.

Forewings ample; costa in $\delta$ arched uniformly from base to apex; in $q$ more arched at base, and slightly concave about centre; apex very slightly and bluntly produced; hindmargin with slight elbow in middle at end of third submedian, vertical above, oblique below the elbow. Hindwings ample, broad; hindmargin well rounded towards the anal angle; irregular above; a slight blunt projection at end of third median nervule, and a more prominent one at end of first subcostal, which is more conspicuous in the $q$ than in the $\delta$. Palpi well developed, porrect; second joint large, broad; third minute, pointed, drooping; tongue present ; antennae pectinated in both sexes to the apex, in the $\delta$ much more strongly than in $q$. Hind tibiae slightly thickened, with two pairs of very long spurs.

Type: Xyloscia subspersata Feld. (Hemerophila).

\section{Seleniopsis gen. nor.}

Forewings twice as long as broad; costa rather abruptly arched at base, thence faintly convex to apex, which is blunt; hindmargin in the upper half vertical, rather irregular, elbowed in middle, thence to anal angle obliquely concave; anal angle well marked. Hindwings quite as broad as forewings, rounded at apex; hindmargin bluntly crenulated, and with a similar concavity to that of the forewings before the anal angle. Antennae rather short, laminated, in the $\delta$ very faintly pubescent; palpi porrect, extending beyond the face, last joint pointed, drooping; lower part of forehead with a central small projecting tuft of scales between and above the palpi; tongue present; hind tibiae in $\delta$ somewhat thickened, with two pairs of short, adjacent spurs; hind tarsi short. Neuration: discocellular angulated; the upper arm oblique inwards; the lower outwards. Forewings first median at fourfifths; second and third from the lower end of cell; lower radial from centre of discocellular; upper from upper end of cell; first subcostal from about half the cell; the other four on a common stem which rises shortly before end. Hindwings with costal approximated to subcostal for about half the length of cell, then divergent; two subcostals on a rather long common stem; first median at two-thirds; second before the end, third from the end of cell. In the forewings are two elongated bladdery patches near the base, one above the other below the submedian fold, the latter the larger, and extending to the base.

Type: Seleniopsis evanescens Butler (Endropia).

\section{Pareilicrinia gen. nov.}

Like Eilicrinia Huib., but the forewings not excavated below the apex; apex minutely produced, the hindmargin obliquely curved, and very slightly sinuous. Hindwings with hindmargin rounded; both wings broader and ampler than in Eilicrinia. Palpi stout, upturned in front of face; in Eilicrinia they are quite small, slender, and porrect. Neuration normal.

Type: Pareilicrinia flava Moore (Noreia).

\section{Pareclipsis gen. nov.}

Forewings with costa nearly straight, convex at base and just before apex; apex blunt, square; hindmurgin with distinct elbow above middle, at end of third median 
nervule, oblique thence to anal angle, vertical, and slightly concave above it. Hindwings with a decided projection at end of third median nervule, rounded above it, and straight below. Palpi upturned, projecting beyond face, terminal joint small; tongue present; antennae laminated, thicker in $\delta$ than $q$; hind tibiae in $\delta$ not thickened with two pairs of well developed spurs. Neuration normal.

Type: Pareclipsis gracilis Butler (Endropia).

Parepione gen. nov.

Closely related to Endropiodes Warr., with which it agrees in all points, except the palpi, which are twice as long, straight, porrect; the second joint hairy on both sides, the third long and pointed. The hindmargin of the forewings is without any perceptible elbow, being gradually curved from apex to anal angle.

Type: Parepione grata Butler (Epione).

\section{Endropiodes gen. nov.}

Forewings with costa arched at base, then nearly straight; apex blunt, square; hindmargin curved, more obliquely in its lower half; anal angle obtuse. Hindwings with hindmargin well rounded, but with a scarcely perceptible indentation opposite the cell. Antennae of $q$ subserrate, pubescent; of $\delta$ fully pectinated, the pectinations ciliated and thickened at their apex; forehead rather projecting in its lower part ; tongue present; palpi porrect, the second joint hairy, third short, blunt; hind tibiae of $\delta$ not thickened, with two pairs of spurs. Neuration : forewings, first subcostal from two-thirds, anastomosing with costal ; second subcostal from seven-eighths, anastomosing with first subcostal; the other three on a common stem from just before end of cell, approximating or anastomosing with the second; scaling coarse and dense.

Type: E. indictinaria Bremer (Macaria).

\section{Crypsicometa gen. nov.}

Forewings with costa uniformly convex from base to apex; apex rounded; hindmargin obliquely eurved. Hindwings with round hindmargin. Antennae laminated, in $\delta$ slightly pubescent; tongue present; palpi short, weak, not reaching beyond face; hind tibiae in $\delta$ not thickened, rather long, with two pairs of long, slender spurs. Neuration : discocellulars with the lower arm slightly oblique; first median at threefourths, second just before end of cell, third from the end; lower radial from the centre of discocellular, upper from top end of cell; last four subcostals on a common stem, which rises shortly before end of cell; first subcostal rising a little before it. Hindwings with costal shortly approximated to subcostal; two subcostal branches from top end of cell; medians as in forewing. On the inner margin of the forewing beneath in the $\delta$ is a tuft of hairs, reaching nearly to half the wing.

Type: Crypsicometa incertaria Leech (Phasiane).

\section{Xanthotype gen. nov.}

Forewings ample, broad; costa curved throughout; apex rectangular; hindmargin vertical at first, then curved to the anal angle, which is distinct. Hindwings broad, the apex rather prominent; hindmargin excavated opposite to the cell, thence 
rounded. Palpi quite short, horizontally porrect; antennae of $\delta$ stoutly pectinated ; of $q$ sharply serrate; tongue present; hind tibiae of $\delta$ with four spurs. Neuration normal.

Type: Xanthotype crocataria Fab.

The genus is intermediate between Angerona and Therapis Hüb., but agrees precisely with neither.

Venilia sospita Drury, from Jamaica, if not actually identical, is certainly congeneric with $X$. crocataria.

\section{Tanaoctenia gen. nov.}

Forewings ample, costa slightly convex; apex rather acute, but not produced; hindmargin oblique, hardly curved; anal angle prominent. Hindwings broad, with a slight angular prominence in the middle. Antennae of $q$ simple, but thickened with scales near the base; of of with very long ciliated pectinations to the tip. Palpi porrect, stout; terminal joint blunt. Neuration : forewings, cell not quite half the length ; first median at two-thirds, second close before end of cell, third from end ; radials as usual ; last four subcostals on common stem from before end of cell ; first subcostal free; all the subcostals closely approximated. Hindwings: costa approximated shortly to subcostal, first subcostal nervule and second median leaving each just before end of cell ; no radial.

Type: T. haliaria Wlk. (Geometra). Owing to their colour this species and several others have been referred to the subfamily Geometrince; but they are really Ennominae, related to Metrocampa, ete.

\section{Subfamlly PROSOPOLOPHINAE.}

Ligidae Auct.

\section{Catophoenissa gen. nov.}

Forewings triangular; costa straight, hardly convex just at apex; hindmargin obliquely curved, subcrenulate; anal angle very well marked. Hindwings broad; hindmargin curved, subdenticulate. Thorax crested behind; forehead rounded; palpi upturned, short, broad, third joint invisible; antennae of $\delta$ shortly but regularly and thickly pectinated; tongue present; hind tibiae with four spurs; pectus and femora hairy. Neuration : forewings, cell a little longer than half the wing; first median at three-quarters; second and third close together, the latter from the angle of the cell ; radials as usual ; fifth subcostal from shortly before end of cell; second, third, and fourth on a common stem, arising before the first ; first subcostal free, but approaching stem of the next three. Hindwings: costal approximated to subcostal for some little distance; two subcostals from upper end of cell; medians as in forewings : no radial.

\section{Type: C. dibapha Feld. (Epimecis).}

\section{Chloroclydon gen, nov}

Forewings with costa arched at base, then straight to the apex, which is slightly prominent ; hindmargin denticulate, the teeth at the end of the third median nervule, the upper radial, and that at the apex being larger than the rest; lower half of hindmargin more oblique than the upper; anal angle rounded. Hindwings ample, well rounded, with regularly crenulate hindmargin. Face with a tuft of porrect hairs; 
antennae of $q$ simple; of $\delta$ thickened, laminated; palpi long, porrect, second joint hairy, third as long as second,'smooth and more slender; tongue present. Neuration: forewings, cell more than half the length of wing and rather broad; first median nervule from three-fourths, second close before end, third from the end of the cell ; lower radial from the centre of the discocellular; upper from top angle of cell ; fifth subcostal separate, from the subcostal nervure shortly before end of cell; second, third, and fourth on a common stem; first subcostal free. Hindwings: costal running close to subcostal for half the length of cell, then curving away; two subcostals close together from upper end of cell ; medians as in forewings; scaling coarse and loose.

Type: Chloroclydon usneata Feld. (Scotopterix?).

\section{Chrysomima gen. nov.}

Forewings elongated; costa gradually arched from base to apex, before which it is even very slightly concave; apex shortly prominent; hindmargin with upper half vertical, lower half oblique, strongly dentate; the teeth at the apex, at the end of the upper radial, and of the second and third median nervules being the largest, the two latter forming a bifid blunt projection in the middle of the margin ; anal angle obtuse, but well defined. Hindwings rounded, with subcrenulate hindmargin. Antennae ( $q$ ) simple, fine; tongue present (mouth parts damaged); abdomen very stout and distended. Neuration as in Chloroclydon, but the second and third medians in both wings and the two subcostals in the hindwings rise from a point together. The costal of the hindwings is approximated to the subcostal for only a short distance; scaling smooth and fine; the markings like those of Ischnopteris Hüb.

Type: Chrysomima semilutearia Feld. (Gonodontis?).

Axiodes gen. nov.

Forewings elongate; costa decidedly concave between base and apex; hindmargin curved, irregularly crenate; anal angle square. Hindwings elongate, with hindmargin deeply and irregularly crenate. Forehead, head, and thorax hairy; tongue present; antennae in $\delta$ pectinated; palpi with second joint hairy, third long, fusiform; hind tibiae with two pairs of spurs. Neuration : forewings, cell two-thirds as long as wing ; first median nervule from five-sixths, second and third from lower end of cell ; lower radial from middle of discocellular ; upper radial from upper angle; last four subcostals on common stem which rises some way before end of cell, the second, third, and fourth rising from the fifth at an abrupt angle; first subcostal free, as far as can be seen without denuding the type. Hindwings with costal approximated to subcostal for half the length of cell; the two subcostals, and the last two medians from upper and lower end of cell respectively.

Type: A. insciata Feld. (Axia).

\section{Erilophodes gen. nov.}

Forewings elongated; costa straight except just before apex, which is blunt; hindmargin oblique, slightly bent below middle; anal angle well marked. Hindwings with inner angle rounded, and hindmargin hardly curved. Abdomen of o long and slender, with strong erect tufts of scales on each segment; antennae of $\delta$ pectinated, with apex simple; of $q$ finely subserrate; palpi porrect, shortish; third joint 
pointed, drooping; tongue well developed; hind tibiae of $\delta$ with four spurs. Neuration: forewings, cell two-thirds of wing; first median at five-sixths, second close before end, third from end of cell ; radials normal ; last four subeostals on a common stem; first free. Hindwings : cell two-thirds of wing; discocellular incurved; costal approximated to subcostal for quite two-thirds; two subcostals and last two medians from ends of cell.

Type: Erilophodes colorata sp. nov.

Erilophodes colorata sp. nov.

Forewings white, dusted with black atoms, and suffused in parts with rosy brown and black; a subcostal curved black streak, distinct on inner margin and not reaching costa, but running basewards along inner margin, and black on costa at extreme base; second line at one-third, black, sinuous outwards, reaching inner margin beyond middle, in a small sinus, containing a red brown blotch; exterior line at two-thirds, black, denticulate, running outwards to the radial, then inwards to near the inner margin, where it again is bent outwards; costa tinged with reddish brown; interval between subbasal and second lines whitish, unsuffused, except on costa and inner margin; central region between second and exterior line suffused with dull reddish brown, and in lower half with blackish, and with a distinct black cell spot; exterior line followed on costa by a deep black bloteh, and on inner margin by a rosy one; marginal area whitish, towards the hindmargin itself strongly suffused with rosy brown; fringe chequered white and black. Hindwings pure white, dusted with black atoms in the outer half; more so in $q$ than $\delta$; an interrupted blackish curved submarginal line in $q$, crossing the dull black cell spot; in the $\delta$ only the cell spot is represented; a blackish blotch on hindmargin above anal angle. Collar, vertex, and face white; antennae brown; thorax black; abdomen white with the tufts black. Underside white with the costa spotted with black, and the markings showing only on the costal half; underside of abdomen and pectus white; legs whitish, spotted with grey.

of. Expanse of wings: 32 to $34 \mathrm{~mm}$.

The rosy suffusion is more pronounced in the $f$ than the $\delta$.

Anatossa nom. nov.

This name is proposed for Declana niveata Butler = Atossa niveata Meyr.; the name Atossa being already doubly preoceupied 


\section{$2 \mathrm{BHL}$ Biodiversity Heritage Library}

Warren, William. 1894. "New genera and species of Geometridae." Novitates zoologicae : a journal of zoology in connection with the Tring Museum 1, 366-466. https://doi.org/10.5962/bhl.part.24566.

View This Item Online: https://www.biodiversitylibrary.org/item/24179

DOI: https://doi.org/10.5962/bhl.part.24566

Permalink: https://www.biodiversitylibrary.org/partpdf/24566

\section{Holding Institution}

Natural History Museum Library, London

\section{Sponsored by}

Natural History Museum Library, London

\section{Copyright \& Reuse}

Copyright Status: Public domain. The BHL considers that this work is no longer under copyright protection.

This document was created from content at the Biodiversity Heritage Library, the world's largest open access digital library for biodiversity literature and archives. Visit BHL at https://www.biodiversitylibrary.org. 